\title{
Tonian-Cryogenian boundary sections of Argyll, Scotland
}

Fairchild' et al.

\section{Highlights}

- Robust Sr- and C- isotope stratigraphy despite greenschist facies metamorphism

- Islay carbonates have molar tooth structure and low positive $\delta^{13} \mathrm{C}$

- Cryogenian base at $9 \mathrm{~m}$ below diamictite, above negative $\delta^{13} \mathrm{C}$ (Garvellach) anomaly

- Ice-rafted deposits overlap with shoaling, evaporative carbonates on the Garvellach Islands

- Simple late Tonian Neoproterozoic section, $1.5 \mathrm{~km}$ thick, on seabed off the Garvellachs

Revised version Precambrian Research 2nd August 2017 


\section{Tonian-Cryogenian boundary sections of Argyll, Scotland}

Ian J. Fairchild ${ }^{a}, 1$, Anthony M. Spencer ${ }^{b}$, Dilshad O. Ali ${ }^{c}$, Ross P. Anderson ${ }^{d}$, Roger Anderton ${ }^{\mathrm{e}}$, Ian Boomer $^{\mathrm{a}}$, Dayton Dove ${ }^{\mathrm{f}}$, Jonathan D. Evans ${ }^{\mathrm{a}}$, Michael J. Hambrey ${ }^{\mathrm{g}}$, John Howe ${ }^{\mathrm{h}}$, Yusuke Sawaki', Graham A. Shields ${ }^{j}$, Alasdair Skeltonk, Maurice E. Tucker', Zhengrong Wang ${ }^{\mathrm{m}}$, Ying Zhou ${ }^{\mathrm{j}}$

${ }^{a}$ School of Geography, Earth and Environmental Sciences, University of Birmingham, Birmingham B15 2TT, UK

${ }^{b}$ Madlavollveien 14, 4041 Hafrsfjord, Norway

${ }^{c}$ Department of Earth Sciences, Royal Holloway University of London, Egham, Surrey TW2O OEX, UK

${ }^{d}$ Department of Geology and Geophysics, Yale University, 210 Whitney Avenue, New Haven, Connecticut, 06511, USA

${ }^{e}$ Kilmichael House Kilmichael Glassary, Lochgilphead, Argyll, PA31 8QA, UK

${ }^{f}$ British Geological Survey, Murchison House, West Mains Rd, Edinburgh EH9 3LA, UK

${ }^{g}$ Centre for Glaciology, Department of Geography and Earth Sciences, Aberystwyth University, Aberystwyth, Ceredigion SY23 3DB, UK

${ }^{h}$ Scottish Association for Marine Science, Scottish Marine Institute, Oban PA37 1QA, UK

' Department of Earth Science and Astronomy, The University of Tokyo, 3-8-1 Komaba, Meguro-ku, Tokyo, 1538902, Japan

${ }^{j}$ Department of Earth Sciences, University College London, Gower Street, London WC1E 6BT, UK.

${ }^{k}$ Department of Geological Sciences, Stockholm University, 10691 Stockholm, Sweden

' School of Earth Sciences, University of Bristol, Wills Memorial Building, Queen's Road, Bristol, BS8 1RJ, UK

${ }^{m}$ Department of Earth and Atmospheric Sciences, The City College of New York, CUNY, New York, New York, 10031, USA

\footnotetext{
${ }^{1}$ Corresponding author at School of Geography, Earth and Environmental Sciences, University of Birmingham B15 2TT, UK. Tel: +441214144181. E-mail address: i.j.fairchild@bham.ac.uk (I.J.Fairchild)
} 


\section{ABSTRACT}

The Tonian-Cryogenian System boundary is to be defined at a GSSP (Global Boundary Stratigraphic Section and Point) beneath the first evidence of widespread glaciation. A candidate lies within the Dalradian Supergroup of Scotland and Ireland, which is least deformed and metamorphosed in Argyll, western Scotland. We present new stratigraphic profiles and interpretations from the Isle of Islay and the Garvellach Islands, update the chemostratigraphy of the Appin Group Tonian carbonates underlying the thick (ca. $1 \mathrm{~km}$ ) glacigenic Port Askaig Formation (PAF) and demonstrate an environmental transition at the contact.

The Appin Group forms a regionally extensive, $>4 \mathrm{~km}$-thick, succession of limestones, shales and sandstones deposited on a marine shelf. On Islay, the upper part of the lithostratigraphy has been clarified by measuring and correlating two sections containing distinctive stratigraphic levels including molar tooth structure, oolite, stromatolitic dolomite and intraclastic microbial mounds. Significantly deeper erosion at the unconformity at the base of the overlying PAF is demonstrated in the southern section. Carbonate facies show a gradual decline in $\delta^{13} C_{\text {VPDB }}$ from +5 to $+2 \%$ o upwards.

In NE Garbh Eileach (Garvellach Islands), a continuously exposed section of Appin Group carbonates, $70 \mathrm{~m}$ thick, here designated the Garbh Eileach Formation (GEF), lies conformably beneath the PAF. The GEF and the GEF-PAF boundary relationships are re-described with new sedimentological logs, petrological and stable isotope data. Interstratified limestone and dolomicrosparite with $\delta^{13} \mathrm{C}$ of -4 to $-7 \%$ (a feature named the Garvellach anomaly, replacing the term Islay anomaly) are overlain by dolomite in which the isotope signature becomes weakly positive (up to $+1 \%$ ) upwards. Shallow subtidal conditions become peritidal upwards, with evidence of wave and storm activity. Gypsum pseudomorphs and subaerial exposure surfaces are common near the top of the GEF. The basal diamictite (D1) of the PAF is rich in carbonate clasts similar to slightly deeper-water parts of the underlying succession. D1 is typically several metres thick with interstratified sandstone and conglomerate, but dies out laterally. Scattered siliciclastic coarse sandstone to pebble conglomerate with dropstones associated with soft-sediment deformation is interbedded with carbonate below and above D1. Dolomite beds with derived intraclasts and gypsum pseudomorphs are found above D1 (or equivalent position, where D1 is absent).

Published and new $\mathrm{Sr}$ isotope studies, including successive leach data, demonstrate primary Tonian ${ }^{87} \mathrm{Sr} /{ }^{86} \mathrm{Sr}$ values of $0.7066-0.7069$ on Islay, decreasing to $0.7064-0.7066$ in the younger GEF limestones on the Garvellachs, with 1700-2700 ppm Sr. Other typically Tonian characteristics of the carbonates are the Sr-rich nature of limestones, molar tooth structure, and dolomitized peritidal facies with evidence of aridity. Seabed surveys suggesting uniformly-dipping strata and shallow borehole core material illustrate the potential for extending the Tonian record offshore of the Garvellachs.

A candidate Tonian-Cryogenian GSSP is proposed on Garbh Eileach within the smooth $\delta^{13} \mathrm{C}$ profile at the cross-over to positive $\delta^{13} \mathrm{C}$ signatures, $4 \mathrm{~m}$ below the first occurrence of ice-rafted sediment and $9 \mathrm{~m}$ below the first diamictite. Although lacking radiometric constraints or stratigraphically significant biotas or biomarkers, the Scottish succession has a thick and relatively complete sedimentary record of glaciation, coherent carbon and strontium chemostratigraphy, lateral continuity of outcrops and $100 \%$ exposure at the proposed boundary interval.

Keywords:

Neoproterozoic, limestone, glaciation, dolomite, carbon isotopes, strontium isotopes 


\section{Introduction and previous research}

A revolution in our understanding of the evolution of the Earth system during the Neoproterozoic Era has occurred in the last 20 years (Spence et al., 2016; Hoffman et al., 2017). Notably it has been confirmed that on two occasions ice sheets had a global distribution (hence the term panglaciation) and had synchronous onset and terminations. These are the early Cryogenian or Sturtian (717-660 $\mathrm{Ma}$ ) and late Cryogenian or Marinoan (ca. 645 to $635 \mathrm{Ma}$ ) ice ages (Halverson and Shields-Zhou, 2011; Rooney et al., 2014, 2015). Such synchroneity was the basis for the definition of the boundary between Cryogenian and Ediacaran Systems at the base of the cap carbonate overlying Marinoan glacial deposits in South Australia (Knoll et al., 2006) with its associated negative carbon isotope anomaly.

Attention has now turned to defining a basal Cryogenian boundary and the Cryogenian stratigraphic sub-commission seeks to do this beneath the oldest evidence of widespread glaciation, in the meantime adopting a numerical age of $720 \mathrm{Ma}$ as an interim position (Shields-Zhou et al., 2016). Preservation of glacigenic diamictite in a region of low palaeolatitude would support the concept that the associated glaciation was widespread. A combination of stratigraphic approaches has been used in addition to geochronology. The record of ${ }^{87} \mathrm{Sr} /{ }^{86} \mathrm{Sr}$ in marine carbonates shows values climbing through the Neoproterozoic, except for a fall from around 0.707 to as low as 0.7064 just prior to Sturtian glaciation (Halverson et al., 2010; Cox et al., 2016). Also, a negative carbon isotope anomaly has been found in carbonates preceding glaciation in several geographic areas (Halverson and Shields-Zhou, 2011). Currently, a biostratigraphic contribution to the boundary definition is not feasible.

The definition of the basal Ediacaran sediments was facilitated by the near-universal presence of a negative carbon isotope anomaly in a cap carbonate at the base of a major transgressive succession resulting from eustatic sea level rise at the end of glaciation. In contrast, the expected eustatic sea level fall creates difficulties in defining a basal Cryogenian boundary. Shields-Zhou et al. (2016) argued that in the case of a transitional boundary, underlying deposits are likely to represent deep-water deposition of siliciclastic facies in which chemostratigraphy is impractical. Conversely, where shallow-water carbonate facies are present, they are liable to truncation during eustatic sea-level fall. A potential resolution arises where the basin subsidence rate is high, permitting a transition from shallow-marine through coastal to non-marine environments during global eustatic regression. Ali et al. (2017, this volume) argued that the Dalradian glacigenic succession of the Port Askaig Formation (PAF) in western Scotland shows a relatively complete record of events. In September 2013, this region became the first potential location to be visited by the Cryogenian stratigraphic sub-commission to consider its suitability for a Tonian-Cryogenian boundary stratotype and GSSP (Global Boundary Stratigraphic Section and Point). The aim of this paper is to synthesize a wide range of stratigraphic, sedimentological and isotopic data, much of it previously unpublished or new, which confirms and amplifies the chemostratigraphy of the region and, critically, establishes an environmental transition at the onset of glaciation, in a region reconstructed to have lain in the tropics (Li et al., 2013).

The PAF, and the marine carbonate rocks that underlie it, belong to the Dalradian Supergroup, a thick Neoproterozoic to early Palaeozoic succession that forms a NE-SW-trending belt across Ireland and Scotland (Spencer, 1971; Chew and Strachan, 2014; Fig. 1a). The rocks were deformed in the Grampian Orogeny at around $470 \mathrm{Ma}$ (Chew and Strachan, 2014), but are at their lowest state of deformation and metamorphic grade in the Argyll District of western Scotland (Fig. 1b). Here the lower contact of the PAF is observed on the Isle of Islay and a chain of small islands known as the Garvellachs. Stratigraphic and geochronological information on Dalradian rocks is summarized in Fig. 2 where the PAF defines the base of the Argyll Group, which overlies the Appin Group. Confidence in correlating the PAF with the Sturtian glaciation that commenced around 716$717 \mathrm{Ma}$ (Macdonald et al., 2010; Lan et al., 2014; Rooney et al., 2015) arises from two main strands of evidence. Firstly, the pattern of least-altered ${ }^{87} \mathrm{Sr} /{ }^{86} \mathrm{Sr}$ values in limestones shows a highly 
distinctive evolution (Fig. 2f) globally and values as low as 0.7064 found on the Garvellachs (Fig. 2, Sawaki et al., 2010) can only be matched with pre-Sturtian rocks. Secondly McCay et al. (2006) and Prave et al. (2009) have convincingly explained the apparent absence of the second panglaciation, the Marinoan, in the Scottish Dalradian record. Glacigenic deposits and a well-developed carbonate facies closely resembling Marinoan caps are well-developed in Donegal, Ireland, much higher in the Dalradian succession than the PAF. In Scotland, the equivalent levels are deep-water resedimented facies, although a thin cap carbonate is also recognized (Prave et al., 2009) and indirect indicators of cold conditions are also found in Scotland (Dempster and Jess, 2015). However, Stephenson et al. (2013), in a review of the Dalradian Supergroup to introduce the Geological Conservation Review, did not consider these points, and instead equated the PAF with the Marinoan glaciation, based on two arguments. Firstly, Rooney et al. (2011) obtained a young (post-Sturtian) Re-Os age on apparently Appin Group slate further north than our study area. However, the stratigraphic significance of this age was downplayed by Rooney et al. (2014) who argued that, given local structural complexity, there were alternative interpretations of the stratigraphic position of the dated strata. The second point refers to somewhat indirect evidence: the consequence of ages of $\geq 800 \mathrm{Ma}$ (Fig. 2) on intrusive materials in Moinian rocks in NE Scotland that underlie the lowest (Grampian Group) Dalradian strata. It was felt that there was insufficient time to exhume the Moinian rocks and deposit the Grampian and Appin Groups prior to Sturtian glaciation. However, Smith et al. (1999) make it clear that although there is a gap between Moinian rocks and Grampian Group sedimentation, an orogenic unconformity has not been established. For these reasons, we believe that the Sturtian correlation of the Port Askaig Formation is firmly established.

The Appin Group has been subdivided in several regions, allowing long-distance correlation (Rast and Litherland, 1970; Harris et al., 1994), although the contact with the PAF is only exposed in the southern part of the Argyll district. Formations tend to be dominated by arenite, mudrock or carbonate, with carbonates dominating near the top of the Appin Group. The above discussion identifies the Appin Group deposits as Tonian and the sparse published sedimentological information on Islay indicates the presence of subtidal limestones (grainstone, carbonate mudstone and oolite) and peritidal dolomite (Wright, 1988; Fairchild, 1991), which compare with Tonian carbonates in Svalbard (Knoll and Swett, 1990). An exception is the lack of described examples in Scotland of the distinctive early-cemented crack-fills known as molar-tooth structure (Fairchild and Spiro, 1987; Fairchild et al., 1997), but these have now been discovered on Islay and are described below. No body fossils have been recovered from the Appin Group, although stromatolites occur (Fairchild, 1991). Palynological residues from the Dalradian in general are not sufficiently well preserved to be stratigraphically useful (Harris et al., 1994), but the locally minimal state of deformation in the Islay area implies that fossils replaced by early diagenetic phases such as dolomite, calcium phosphate, silica or clay minerals may yet be discovered. In the Bonahaven Formation, which overlies the PAF, probable vase-shaped microfossils were preserved by clay mineral authigenesis (Anderson et al., 2013) and clotted stromatolite microstructures are locally well-preserved (Fairchild, 1980, 1985).

Following pioneering chemostratigraphic studies of Appin Group rocks using trace element geochemistry (Hickman and Wright, 1983; Thomas, 1989), Dalradian Sr-isotope stratigraphy (Fig. 2) was developed by Brasier and Shields (2000) and Thomas et al. (2004), including Appin Group carbonates on Islay. This approach was extended to the Garvellachs by Sawaki et al. (2010) and values as low as 0.7064 obtained, comparing closely to least-altered values of late Tonian carbonates in NE Svalbard, NE Greenland and NW Canada. This stratigraphy is robust because of high Sr contents (often $>2000 \mathrm{ppm}$ ) in many of the limestones, probably arising from an originally aragonitic mineralogy (Hickman and Wright, 1983), although the stratigraphically lower Ballachulish limestone has a lower Sr content.

Carbon isotope stratigraphic studies were initiated by Brasier and Shields (2000) who had a wide stratigraphic coverage. McCay et al. (2006) and Prave et al. (2009) took a significant step forward when new analyses were combined with improved field evidence of stratigraphic 
relationships, particularly in relation to glacial units. Prave et al. (2009) generated a $\delta^{13} \mathrm{C}$ synthesis for the whole Dalradian, comparing it with the global pattern (Halverson, 2006). A key new observation was that the sub-PAF carbonates on the Garvellachs contain the top of a distinct negative $\delta^{13} \mathrm{C}$ anomaly with values of -4 to $-6.6 \%$ rising to 0 to $+1 \%$ upwards. This was named the Islay anomaly (after the stratigraphic unit), a name attributed by Prave (2009) to a personal communication from $\mathrm{G}$. Halverson. The $\delta^{13} \mathrm{C}$ values of the anomaly were confirmed by Sawaki et al. (2010) who linked their observations to numbered beds original described by Spencer (1971). A negative anomaly of similar magnitude has been recorded beneath presumed Sturtian glacial deposits in NE Greenland (Fairchild et al., 2000), Svalbard (Halverson, 2006) and NW Canada (Rooney et al., 2014; Strauss et al., 2014) and there has been a tendency in the literature to use the term Islay anomaly whenever one prominent anomaly occurs. A critical issue in Tonian chemostratigraphy is whether these anomalies are actually synchronous. Two examples in NW Canada are constrained by radiometric dates. In the Coal Creek inlier of Yukon $\delta^{13} \mathrm{C}$ values fall from +4 to $-6 \%$ before recovering to $-2 \%$ at the top of the Callison Lake dolomite unit and there is a ReOs date of $739 \pm 6.1 \mathrm{Ma}$ immediately before the anomaly (Strauss et al., 2014). In the Coppercap Formation of the Coates Lake area of Northwest Territories $\delta^{13} \mathrm{C}$ falls from -3 to $-7 \%$ o upwards, before rising to a plateau of +6 ; a Re-Os date of $732 \pm 3.9$ Ma was obtained where the values had just turned positive (Rooney et al., 2014). The high $\delta^{13} \mathrm{C}$ interval is absent above the anomaly in Scotland, implying the latter succession is truncated, if the anomalies are the same (Shields-Zhou et al., 2016). Alternatively, if a transition to the base of the PAF on the Garvellachs can be established, the underlying $\delta^{13} \mathrm{C}$ anomaly ought to be close to the $717 \mathrm{Ma}$ presumed onset of glaciation.

In this paper, we draw up measured stratal profiles and sedimentological and petrological descriptions for the poorly-exposed successions on Islay for the first time and provide many new $\delta^{13} \mathrm{C}$ and ${ }^{87} \mathrm{Sr} /{ }^{86} \mathrm{Sr}$ data. Although some negative $\delta^{13} \mathrm{C}$ values are known from Islay in tectonized areas (Brasier and Shields, 2000; Skelton et al., 2015), we show that the $\delta^{13} \mathrm{C}$ values are consistently positive in the main stratal sections of northern Islay where the PAF has an erosional base. On the Garvellachs, we provide new detailed sedimentological logs and petrological observations for the perfectly exposed sections and add many new $\delta^{13} \mathrm{C}$ analyses. We show that the negative carbon isotope anomaly is well-constrained stratigraphically and demonstrate that it lies beneath a transitional onset to glacial conditions. The sub-PAF carbonates of the Garvellachs are, therefore, younger than on Islay. We argue that this negative anomaly is not the same as those recorded in Canada and since it also does not occur on Islay, have renamed it in this paper the Garvellach anomaly.

\section{Methods}

\subsection{Field and petrological methods}

Detailed field mapping at the Lossit section on Islay on 1:2500-scale orthorectified aerial photographs was supplemented by a traverse in the Keills-Persabus area (Figs. 1, 3). Bed thicknesses in well-exposed sections were measured directly using the Jacob's staff method (also the standard method in the Garvellachs), but the intermittent nature of exposure on Islay made it necessary to calculate stratigraphic positions using $30 \mathrm{~m}$ tape and Abney level or, for longer distances, GPS readings and altitude obtained from $5 \mathrm{~m}$ contours on the Ordnance Survey 1:25000 map.

Stratigraphic thickness $=L^{*} \sin \delta^{*} \cos \alpha * \sin \beta+L^{*} \sin (\alpha+\delta) * \cos \beta$ where $L=$ length of tape (or horizontal distance between GPS points), $\delta=$ angle of rise of tape, $\alpha=$ angle of dip of bedding, $\beta=$ angle between direction of tape and dip direction.

Details of the sample suite are given in the supplementary information text and Tables S1 to S3. Information on samples from which Sr and C isotope data had been obtained from previous work 
by Brasier and Shields (2000), Thomas et al. (2004), and Sawaki et al. (2010) are also included. The samples used to construct carbon isotope profiles by Prave et al. (2009) are included in our crossplot diagrams. Substantial new carbon, oxygen and strontium isotope data have been obtained from new collections. All significant variations in lithology have been constrained through petrological study of thin sections or stained polished samples.

\subsection{Oxygen and carbon isotopes}

The studies cited above and our new work have employed conventional methods to derive $\delta^{13} \mathrm{C}$ and $\delta^{18} \mathrm{O}$ values on relatively homogeneous areas of carbonate samples. Results are expressed in \%o with respect to the V-PDB standard. As explained in the supplementary information and Table S4, we take the analytical uncertainty to be that of the highest of those quoted amongst the multiple laboratories involved, that is $\pm 0.3 \%$ for $\delta^{13} \mathrm{C}$ and $\pm 0.5 \%$ for $\delta^{18} \mathrm{O}$. An additional uncertainty arises for measuring dolomite samples, from the use of different reaction temperatures to dissolve dolomites in orthophosphoric acid, and so we do not interpret differences in $\delta^{18} \mathrm{O}$ of $<1 \%$ o for in dolomite.

\subsection{Strontium isotopes and trace elements}

In the supplementary information (text and Figures S1 to S5) we compare the different techniques used in published papers in our compilation together with two sets of new data (referred to as Anderson and YZ). Although various instrumental configurations have been used in different laboratories, all ${ }^{87} \mathrm{Sr} /{ }^{86} \mathrm{Sr}$ values are normalized to an NBS987 standard value of 0.71024 or 0.71025 . The key differences in approach lie at the sample dissolution stage, and in some cases $\mathrm{Rb}$ in leachates prompted a correction to be made for decay of ${ }^{87} \mathrm{Rb}$ within carbonate to ${ }^{87} \mathrm{Sr}$. In summary, these factors make a difference in the fifth decimal place and possibly up to 0.0001 to 0.0002 . This is discussed in more detail in section 6.1 below, when describing the results of the Anderson study.

\section{Preservation of pre-metamorphic textures and chemistry}

Dalradian carbonates in the Argyll region have been metamorphosed to greenschist facies. On Islay, the peak metamorphic temperatures were $410-470{ }^{\circ} \mathrm{C}$, and maximum pressures $1 \pm 0.2 \mathrm{GPa}$ (Skelton et al., 1995). Biotite in pelitic rock layers from the Garvellachs confirm similar metamorphic temperatures. Rocks are also mostly penetratively deformed with structures flattened in or rotated towards the cleavage, where visible. Also, $\delta^{18} \mathrm{O}$ studies on limestones in the axial zone of the Islay Anticline demonstrate localized resetting of carbon and oxygen isotopes in carbonates during metamorphism (Skelton et al., 2015). Yet previous workers have shown that remarkable preservation of $\delta^{13} \mathrm{C}$ and ${ }^{87} \mathrm{Sr} /{ }^{86} \mathrm{Sr}$ isotope signatures in pure carbonate is normal (Sawaki et al., 2010) and even that visible tectonic deformation of mudrock is locally absent (Anderson et al., 2013). The key to this paradox is that metamorphic phenomena are highly heterogeneous, being promoted by active fluid flow at certain lithological or tectonic boundaries or in anticlinal cores (Skelton et al., 2015), removing the products of metamorphic reactions and allowing them to proceed further (Fairchild, 1985). Once metamorphosed, the rocks became impermeable and are geochemically modified only along fracture systems such as those that led to the development of dolomite veining and sulphide mineralization in the late Carboniferous on Islay (Parnell et al., 2000), and Carboniferous and more common Palaeogene igneous dykes in Argyll.

As explained more fully in the supplementary information and associated Figures S6-S9, we have focused on sedimentary sections that are not unusually sheared or flattened.. Texturally, the biggest changes are cleavage development in pelitic lithologies, including the redistribution of quartz by pressure dissolution and reprecipitation (Fig. S7). However, pre-metamorphic burial diagenetic quartz and albite domains commonly occur in mixed dolomitic-siliciclastic lithologies (Fig. S7g-i) and 
these can be confused with sedimentary quartzose laminae. Moreover, we have sampled mostly pure carbonate lithologies that are less susceptible to the development of new metamorphic minerals such as phlogopite or chlorite by reaction of carbonate with silicate phases. There is a lack of metamorphic alteration patterns (Skelton et al., 2015) such as very low $\delta^{18} \mathrm{O}$ with varying $\delta^{13} \mathrm{C}$ (Fig. S9). However, there is a spread of $\delta^{18} O$ values as would be expected to have developed prior to metamorphism, as shown by suites of Neoproterozoic carbonates from unmetamorphosed successions (e.g. Fairchild et al., 1990). This variation arises since primary metastable phases are stabilized under different diagenetic conditions (Spence et al., 2016). Dolomite is more resistant to an increase in crystal size than limestone during deep burial, but recrystallization of a pure carbonate does not necessarily result in chemical change (Fig. S6a,b cf. Fig. S7a-c)). Evidence for this is provided by the similarity of most of our data in $\delta^{13} \mathrm{C}-\delta^{18} \mathrm{O}$ space with unmetamorphosed Tonian successions (cf. Fig. S8b, S9a), e.g. the well-preserved deposits of NE Svalbard (Fairchild and Spiro, 1987; Halverson et al., 2005, 2007). Also, in the specific sections we studied, $\delta^{13} C$ signatures were strongly buffered by pre-existing host rock values even where fully metamorphic textures have developed (Fig. S6d, e).

\section{Islay succession and palaeoenvironments}

\subsection{Lithostratigraphy}

Outcrops of the Appin Group and its contact with the PAF only occur inland in discontinuous exposures. Alternations of slate and locally dolomitized limestone units occur, varying in dip and extensively faulted, leading to uncertainties in correlation and stratal thickness. In the original survey of Islay, the term Islay Limestone was used as a general term for limestones in central Islay (Wilkinson, 1907) and later for only the uppermost of them (Rast and Litherland, 1970), but it was never formally defined and is not used on any current British Geological Survey map. A modern stratigraphic nomenclature of formations and members was introduced in a new map (BGS, 1997), produced as a desk study including available unpublished data. No descriptions accompanied the map and stratal thicknesses were only estimated crudely. This scheme, with the modifications introduced in this paper, is given in Table 1. 
Table 1: Lithostratigraphic units on the Garvellachs and Islay. New and revised units shown in bold. Abbreviations: $\mathrm{Fm}=$ Formation, $\mathrm{Mb}=$ Member. See sections 4.1 and 5.1 for discussion.

Existing nomenclature: Spencer (1971), Fairchild (1991), BGS (1997)

\begin{tabular}{|c|c|c|}
\hline \multirow[t]{2}{*}{ Garvellachs } & $\begin{array}{l}\text { Port Askaig Tillite Fm with sharp basal } \\
\text { contact }\end{array}$ & $\begin{array}{l}\text { Port Askaig Tillite Fm (PAF). (Member } 1 \text { fully } \\
\text { developed). Interstratification of facies around } \\
\text { basal contact }\end{array}$ \\
\hline & $\begin{array}{l}\text { Islay Limestone (informal) fm (72 m } \\
\text { seen on Garbh Eileach) }\end{array}$ & $\begin{array}{l}\text { Garbh Eileach Fm (GEF) } \\
(70 \mathrm{~m}), \text { base unexposed (sea) }\end{array}$ \\
\hline \multirow[t]{4}{*}{$\begin{array}{l}\text { Islay, Keills- } \\
\text { Persabus area }\end{array}$} & $\begin{array}{l}\text { Port Askaig Tillite Fm, basal part of } \\
\text { Member } 1 \text { missing and with erosional } \\
\text { basal contact }\end{array}$ & No new observations \\
\hline & $\begin{array}{l}\text { Lossit Limestone Fm, Persabus Mb (ca. } \\
\text { 50-100 m), mixed lithologies }\end{array}$ & $\begin{array}{l}\text { Persabus } \mathrm{Mb} \text {, thickness }>100 \mathrm{~m} \text {, lower contact } \\
\text { apparently conformable, unexposed }\end{array}$ \\
\hline & $\begin{array}{l}\text { Lossit Limestone Fm, Keills Mb, } 70 \text { m, } \\
\text { dominantly limestone }\end{array}$ & $\begin{array}{l}\text { Keills } \mathrm{Mb} \text {, measured section, ca. } 290 \mathrm{~m} \text {, } \\
\text { unexposed base }\end{array}$ \\
\hline & $\begin{array}{l}\text { Lossit Limestone Fm, Gleann nan } \\
\text { Gabhar Slate Mb., } 40 \mathrm{~m}\end{array}$ & $\begin{array}{l}\text { As left, but thickness varies, possibly due to } \\
\text { faulting }\end{array}$ \\
\hline \multirow[t]{7}{*}{$\begin{array}{l}\text { Islay, Lossit } \\
\text { area }\end{array}$} & $\begin{array}{l}\text { Port Askaig Tillite Fm, basal part of } \\
\text { Member } 1 \text { missing and with erosional } \\
\text { basal contact }\end{array}$ & No new observations \\
\hline & $\begin{array}{l}\text { Lossit Limestone Fm, Persabus Mb (ca. } \\
100 \mathrm{~m} \text { ), slate, limestone and dolomite }\end{array}$ & $\begin{array}{l}\text { Reassigned to Keills Mb by correlation with } \\
\text { Keills-Persabus area }\end{array}$ \\
\hline & $\begin{array}{l}\text { Lossit Limestone Fm, Keills Mb, } 70 \text { m, } \\
\text { dominantly limestone }\end{array}$ & $\begin{array}{l}\text { Keills Mb: } \mathbf{2 9 0} \mathbf{~ m} \text { (including } 120 \text { m at top } \\
\text { originally assigned to Persabus Fm). Sharp, non- } \\
\text { erosional base. }\end{array}$ \\
\hline & $\begin{array}{l}\text { Lossit Limestone Fm, Gleann nan } \\
\text { Gabhar Slate } \mathrm{Mb}, 40 \mathrm{~m}\end{array}$ & $\begin{array}{l}\text { Lateral variation in thickness from } 0 \text { to } 50 \mathrm{~m} \text {, } \\
\text { thickening to west, variation thought to be } \\
\text { primary. Base unexposed. }\end{array}$ \\
\hline & $\begin{array}{l}\text { Lossit Limestone Fm, Kilslevan } \\
\text { Limestone } \mathrm{Mb} \text { (ca } 50 \mathrm{~m} \text { ) }\end{array}$ & $\begin{array}{l}\text { Thickness } 50 \text { to }>130 \mathrm{~m} \text {, variation thought to be } \\
\text { both primary and due to faulting. Unexposed } \\
\text { base }\end{array}$ \\
\hline & $\begin{array}{l}\text { Mullach Dubh Phyllite Fm, thickness } \\
\text { unknown }\end{array}$ & $\begin{array}{l}\text { Thickness estimated from outcrop width as ca. } \\
400 \mathrm{~m} \text {. Base not exposed. }\end{array}$ \\
\hline & $\begin{array}{l}\text { Ballygrant Fm, Storakaig Limestone } \\
\mathrm{Mb}(150-250 \mathrm{~m})\end{array}$ & No new observations \\
\hline
\end{tabular}

Starting with the oldest unit in Table 1, no new observations are provided for the Ballygrant Formation (Storakaig Limestone Member) which consists of dark-grey, stratified micritic, oolitic and intraclastic limestone, but we assess chemostratigraphic information from Brasier and Shields (2000) and Thomas et al. (2004) later in the paper. The overlying poorly exposed pelitic Mullach Dubh Phyllite Formation contains some deformed limestone units which Skelton et al. (2015) demonstrated have had significant resetting of their oxygen and carbon isotope signatures. The overlying Lossit Formation is best exposed overall at the Lossit section (Fig 1b) which was also sampled in the chemostratigraphic studies of Prave et al. (2009) and Sawaki et al. (2010). At this location, on the eastern flank of the Islay Anticline, minor folding is rare. A simplified version of our new map is shown in Fig. $3 b$, together with a vertical cross-section along the best-exposed line ("main traverse"). This shows that the limestone section attributed to the Storakaig Member in Sawaki et al. (2010, their Fig. 1c) is the Kilslevan Limestone Member and that thought to be the Kilslevan is the lower Keills Member.

The Kilslevan Limestone Member comprises dark-grey, micritic, oolitic and intraclastic limestones, with minor clay and siliciclastic silt impurities and is locally partly dolomitized. Cross- 
stratification is visible locally, as is molar tooth structure, but the latter is much better seen in the younger Keills Member where it is described below. We have combined chemostratigraphic measurements of Sawaki et al. (2010) along our main traverse line with our own sampling from the top of the unit, as seen in a 20 m-thick traverse around NR 410640 . The overlying pelite unit, the Gleann nan Gabhar Member, thickens to the west, provisionally attributed to thickening towards a depocentre. A sharp gradation, over a few centimetres, up into the limestone of the overlying Keills Member is seen at several locations. All the units described so far are consistently interpreted as shelfal in the literature, with mud members representing deeper-water conditions (Wright, 1988).

The Keills Member is lithologically diverse (Figs. 4-6), although outcrops are dominantly carbonate. In previous work (Fairchild, 1991; British Geological Survey, 1997), the top of the member has been defined at the first appearance (at the 180-m level on the log, Fig. 4) of distinctive interbedded pelitic and quartz-cemented siliciclastic rock (slate and quartzite, Fig. 6a, b), also characteristic of the basal Persabus Member as seen $4 \mathrm{~km}$ to the north in the Persabus area (Fig. 3a). However, a log through the Keills Member in the Keills-Persabus area demonstrates that the mapped top of the Keills Member there corresponds to a position at around $290 \mathrm{~m}$ on the log. It is therefore more logical to define the top of the Keills Member as the uppermost thick $(>2 \mathrm{~m})$ carbonate unit rather than the first occurrence of interbedded slate and quartzite, particularly as siliciclastic rock is also found lower in the Keills Member (e.g. $150 \mathrm{~m}$ at Lossit and $50 \mathrm{~m}$ at KeillsPersabus). This is strengthened by the correlation of four broad stratigraphic horizons between the two sections as marked on Fig. 4. From bottom to top these are: I. limestone with molar tooth structure in the basal $50 \mathrm{~m}$ (Fig. 5f-j), II. variably dolomitized oolitic limestone in the interval 50-150 $\mathrm{m}$ (Fig. 5c, d), III. a stromatolitic biostrome at around 160-170 m (Fig. 5e), and IV. dolomicrite and wholly dolomitized intraclastic grainstone/microbialite above $200 \mathrm{~m}$ (Fig. 6c-i).

The Persabus Member is difficult to study as it commonly contains small-scale folding and is poorly exposed. There is currently no published stratigraphic profile of the member, nor do chemostratigraphic data exist. Lithologically it comprises pure siliciclastics (slate and quartzite), pure carbonate (ferroan dolomite), and mixed carbonate-siliciclastic sandy conglomerate units.

The base of the PAF is clearly exposed at the Lossit section where the Persabus member is absent. Basal sediments are sandy and conglomeratic (Spencer, 1971) and clearly represent a subaerial erosion surface. Farther west on Islay, poorly exposed limestone conglomerate occurs between limestone and diamictite outcrops, implying a deeper level of pre-PAF erosion here, which is consistent with syn-depositional faulting, as envisaged in the region by Anderton (1985).

\subsection{Sedimentary environments of the Keills Member}

Limestones in the basal $150 \mathrm{~m}$ (Fig. 4) are generally dark-grey coloured (relatively organic-rich, subtidal) and consist of interbedded carbonate mudstone, and intraclastic and oolitic grainstone, which are easiest to recognize on weathered surfaces in the field where grains are preferentially dolomitized (Fig. 5a, c). Decimetre-scale graded units are sometimes observed, as is low-angle stratification reminiscent of hummocky bedding and suggestive of storm action. Conversely, crossstratification more typical of tidalites occurs locally. In one sample, micritic intraclasts $(5-10 \mathrm{~mm})$ have complex shapes with many concave embayments (Fig. 5b). These are reminiscent in size and shape of partly silicified, hematitic and recrystallized calcareous intraclasts described by Maloof et al. (2010) from the mid-Cryogenian Trezona Formation of South Australia. In that study, the morphology, reconstructed from serial sections, was found to be chambered, and interpreted as arising within primitive sponge-like organisms, although that affinity has been questioned (Knoll, 2011; Antcliffe et al., 2014; Anderson et al., 2016). At the very least, this analogy raises the possibilities that the abundance of intraclasts in the lower Keills Member may reflect reworking of early-calcified subtidal buildups.

The most commonly observed distinctive aspect of the lower Keills Member limestone is the presence of molar tooth structure. The term refers to the occurrence of distinctively shaped 
domains, within host micritic carbonate, composed of even-textured microspar, a cavity-filling cement. The Islay examples are similar to the most common variety seen in other successions (Fairchild et al., 1997; Kuang, 2014), i.e. they are upwards- and downwards-tapering sheets (Fig. 5i) that have become ptygmatically compacted during burial (the resulting squiggly cross-sections inspired the term "molar tooth"), but in the Islay case, they have also typically been strongly flattened and rotated by tectonic deformation (Fig. $5 \mathrm{~g}$ ). Their morphology in plan view is locally wellpreserved on karstified limestone pavements, where both poorly linked polygonal varieties (Fig. 5h) and isolated, preferentially oriented cracks are found (Fig. 5f). Fairchild et al. (1997) advocated a seismic origin for the initial cracks, which would fit with the local tectonic context, although other authors have argued for internal gas generation (e.g. Smith, 2016). In every region, molar tooth structure invariably pre-dates the first Cryogenian glaciation (Shields, 2002) and so provides further support for a Tonian age. The reason for this age-restriction is probably related to a distinctive seawater chemistry permitting the rapid cementation of open spaces in subtidal limestones (Shields, 2002), the initial precipitate likely being a metastable carbonate (see reviews in Smith, 2016 and Spence et al., 2016). The host sediment for the molar tooth cracks is microsparry limestone with thin lamination demarcated by carbonaceous impurities (Fig. 5j), like subtidal Tonian examples elsewhere (e.g. Fairchild and Spiro, 1987). Shallow-water conditions are suggested by local interstratification of thin oolitic beds (e.g. at around $9 \mathrm{~m}$, Fig. $5 \mathrm{c}$, and $58 \mathrm{~m}$ in the Lossit section, Fig. 4).

Oolitic deposits, with subordinate intraclastic grainstone, are a feature of the $100-150 \mathrm{~m}$ level in the Keills Member. Units of partly dolomitized cross-stratified grainstone followed, after a gap, by oolite (Fig. 5d) are particularly well-exposed in small old quarries around NR 42076887 at the 80-100 m level at the Keills section. Stromatolitic dolomite is exposed at the $10-15 \mathrm{~m}$ level just east of the line of the Lossit section, and examples are seen at around the 160-m level in both sections. All these examples consist of domal structures a few centimetres across forming parts of larger, albeit poorly exposed bioherms, and are entirely dolomite. The overall morphology and mineralogy are like other Neoproterozoic examples described by Spencer and Spencer (1972), Fairchild (1980) and Fairchild and Herrington (1989). These examples had sufficient context to interpret them as shallow subtidal in origin, with dolomite either being primary or crystallizing close below the sediment surface; a similar origin is envisaged for the Keills Member bioherms. The Lossit example at $163 \mathrm{~m}$ has a distinctive top, being overlain by a flake conglomerate and a graded siliciclastic wacke, suggestive of a severe storm event.

A 2-3 m bed of cross-stratified dolomitic sandstone and a parallel-laminated quartzcemented sandstone occur in the lower Keills Member, implying that siliciclastic environments were established in adjacent parts of the coastal zone, sporadically migrating into the study area. A more significant development of distinctive interbedded sandstones and mudstones is found in the 170$200 \mathrm{~m}$ interval at Lossit, where the sandstones have distinctive erosional (Fig. 6b) or guttered (Fig. 6a) bases and graded tops. Internal lamination is parallel to undulatory, locally hummocky. These characteristics are diagnostic of storm deposits intervening between fair-weather mud deposition.

The upper Keills Member contains spatially restricted, but informative outcrop data. At Persabus, ridges of dolomite run NE sub-parallel to the road E of the farm (Fig. 3a). These rocks are dominated by carbonate mudstone and cross-stratified intraclastic grainstone that, like the stromatolites lower in the member, are completely dolomitic. The dolomicrite appears likely to have formed penecontemporaneously. There is also the local development of complex, vesicular intraclasts, which resemble those found extensively at the 270-m level in the Lossit section, described below. Two locations display equant siliceous concretions several centimetres across (Fig. 6c) which resemble anhydrite concretions known to form in peritidal dolomite in evaporative environments (cf. Fairchild and Herrington, 1989).

The equivalent section at Lossit is relatively well-exposed in its upper $35 \mathrm{~m}$. The lower portion is composed of mostly pale-coloured limestones with rather recrystallized textures, but retaining sufficient structure to show that they are dominantly grainstone and locally oolitic. In contrast, the succeeding dolomitic interval is exceptionally well-preserved (cf. Tucker, 1983), and 
neither in the petrography or their oxygen isotope composition (see next section) do they reveal any metamorphic features. The interval contains thin- to thick-bedded dolomicrite and intraclastic dolomite. There are six repetitions, 0.2-0.8 m thick, of a characteristic motif, which commences with a sandstone layer $1-2 \mathrm{~cm}$ thick succeeded by intraclastic grainstone, sometimes visibly crossstratified. Cross-stratification is steep and in variable directions, implying tidal activity (Fig. 6d). The upper portions are usually cryptic, but in several cases they have a distinctive mounded top with lateral dimensions of $20-50 \mathrm{~cm}$ and relief of several centimetres. Most samples are grainstone, with coarser examples displaying complex intraclasts of which Fig. 6e is representative. Intraclasts range from $\mathrm{mm}$-scale to several $\mathrm{cm}$ in length and have micritic outer walls and internal divisions separated by 0.1-1 mm domains of dolomicrospar and dolospar cement. Some samples have the characteristics of primary carbonate buildups in that they display mottled (Fig. 6f) or laminar (Fig. 6g) textures defined by dolomicrite zones that clearly represent localized early calcification and hence lithification. Although sampled relatively intensively, the complexity of variation of these buildupintraclastic facies prevents a full understanding of their variability. The style of calcification is unusual and contrasts, for example, with Neoproterozoic instances of diffuse calcification of mats within stromatolites (Fairchild 1980) or calcified filaments (Knoll et al., 1993). In the classic Russian stromatolite literature, which used Linnean nomenclature for these organosedimentary structures, the practice was extended to "microphytolites" (Zhuravleva, 1964) which are essentially grains. Although most examples described appear to be normal intraclasts with cementing and leaching phenomena, some figured examples of the form-genus Vesicularites have similarities to the Lossit structures, although are recorded only before and after the Neoproterozoic interval, implying the organisms that created them did not evolve during the Neoproterozoic. Superficially, the intraclasts might be accounted for by early dolomicrite cementation between grains to form grapestones and at their margins to form micrite envelopes. Subsequent dissolution of $\mathrm{CaCO}_{3}$ cores would then give rise to the vesicular appearance. However, the cemented pore spaces in aggregate do not resemble clusters of original grains; the shapes are more complex. They are also smaller and less regular than the bulbous structures in Mid-Cryogenian reefs from South Australia described by Wallace et al. (2014) and attributed to sponge-grade organisms, or complex microbialites. In summary, these inpart microbially bound, and largely intraclastic dolomites attest to the formation of small buildups reworked by strong tidal currents and possibly storms. They are worthy of a detailed study. Following a thin shaly interval, stromatolitic dolomite, which is largely reworked to form cm-scale intraclasts, is the top unit in the Keills Member of the Lossit section. It is truncated by a brecciated, presumed subaerial erosion surface and then overlain by fluvial deposits at the base of the PAF (Fig. $6 \mathrm{~h})$ as shown in Spencer (1971, Fig. 43) there.

\subsection{Carbon isotope stratigraphy}

The stratigraphic distribution of the $\delta^{13} \mathrm{C}$ composition of the different categories of carbonate in the Kilslevan and Keills Members is shown in an isotopic cross-plot in Fig. 7 (oxygen and carbon isotope data are plotted stratigraphically in the supplementary information, Fig. S7). In the following discussion, we justify which petrographic types were included in the final chemostratigraphic profile (Fig. 4).

In Neoproterozoic chemostratigraphy it is observed that carbonates that are wholly dolomitized by texture-retentive dolomite have concordant $\delta^{13} \mathrm{C}$ values with interbedded limestones (Halverson et al., 2005; Spence et al., 2016). The dolomicrite category in Fig. 8, which includes all wholly dolomitized beds with dolomicrite and early dolomicrospar cements (photographs Fig. $5 \mathrm{e}$ and Fig. $6 \mathrm{c}-\mathrm{i}$ ), displays limited variation in $\delta^{13} \mathrm{C}$ at a given stratigraphic level (range of $1.8 \%$ where most intensively sampled at 270-m level), has only weakly negative $\delta^{18} \mathrm{O}$ values (Fig. S7), and lacks any covariation between $\delta^{13} \mathrm{C}$ and $\delta^{18} \mathrm{O}$ : thus, it can safely be included in the dataset. It is notable that the oxygen isotope values are as high as those reached by Neoproterozoic peritidal carbonates in unmetamorphosed regions (Fig. S8b). On the other hand, the dolomicrospar category which partially 
replaces limestones (e.g. Fig. $5 \mathrm{c}$ ) includes low outliers in $\delta^{13} \mathrm{C}$. There is a particularly wide range at the $120 \mathrm{~m}$ stratigraphic level (Fig. S7). Therefore, this petrographic category is excluded from the chemostratigraphy. Epigenetic dolomite (Parnell et al., 2000) values are not dissimilar to other categories, since carbon isotope compositions are presumably buffered by host rock, but they are excluded from the chemostratigraphic analysis on principle.

In the limestones, the only syn-depositional petrological domain that was consistently subsampled is molar tooth calcite. However, it is not plotted separately since it is close in composition to that of the surrounding matrix (mean values of $\delta_{\text {molar tooth }}-\delta_{\text {matrix }}$ is $0.02 \pm 0.36$ for $\delta^{13} \mathrm{C}$ and $+0.35 \pm$ 0.36 for $\delta^{18} \mathrm{O}, \mathrm{n}=7$ ). The Keills limestone category is the only one to display isotopic covariation (dashed blue line on Fig. 7), although this is statistically weak, with $r^{2}$ of 0.19 . The lower limit of the regression line lies close to the lowest Kilslevan limestone values and is close to the mean composition of calcite veins, which is an indication of the composition of metamorphic fluids (Skelton et al., 2015). The regression line implies $\delta^{13} \mathrm{C}$ has been lowered by up to $1 \%$ or the samples with low $\delta^{18} \mathrm{O}$ values. A more detailed discussion regarding this alteration is provided in the supplementary information. These effects have led to the increased scatter in $\delta^{13} \mathrm{C}$ around the top of the Kilslevan Member (Fig. S7), but at other stratigraphic levels the effects appear to be limited. The limestones that appeared most altered in the field (around the 260-m mark) have low $\delta^{18} \mathrm{O}$, but two specimens sub-sampled for dark-grey and white varieties, differing significantly in crystal size (Fig. S6c, d), showed no difference within analytical error in isotope composition and their mean $\delta^{13} \mathrm{C}$ value is close to that of adjacent dolomicrite, stratigraphically above. On the other hand, the limestone samples with highest (least negative) $\delta^{18} \mathrm{O}$ are comparable in value with unmetamorphosed successions elsewhere of similar facies type (Fig. S8b).

In summary, the limestone and dolomicrite samples have been retained for the Keills Member chemostratigraphic summary in Fig. 4 where the major feature is a slight overall decline in values upwards. The Lossit and Keills-Persabus sections show similar values, except around 40-60 m where the Keills data are slightly less positive in $\delta^{13} \mathrm{C}$ than the overall trend.

Although negative $\delta^{13} \mathrm{C}$ values are missing in the studied sections, there has been some confusion about whether the "Islay anomaly" of Prave et al. (2009) actually occurs on Islay (Hoffman et al., 2012; Skelton et al., 2015) and this is one reason for discontinuing the use of the term. The summary derived from the work of Brasier and Shields (2000), McCay et al. (2006) and especially Prave et al. (2009) that was presented in Halverson et al. 2010), Halverson and Shields-Zhou (2011) and Shields-Zhou et al. (2016) correctly depicts the age-relationships of older Islay carbonates with positive $\delta^{13} \mathrm{C}$ values and younger Garvellachs carbonates containing a negative anomaly. However the depiction is a a composite and does not indicate the location of the samples (samples from Ireland are also included). Hoffman et al. (2012) gave priority for the discovery of the Islay anomaly to Brasier \& Shields (2000) on the basis of samples from the Mull of Oa, Islay (Fig. 1b). However, as discussed in the supplementary information, these analyses must be discounted on grounds of their uncertain stratigraphic position and occurrence in highly deformed locations, associated with unusually negative $\delta^{18} \mathrm{O}$ values (Fig. S9b).

\section{Garvellachs succession and palaeoenvironments}

\subsection{Lithostratigraphy}

The Garvellachs have the advantage of complete exposure of the stratigraphy, together with scope for exploring lateral variations and the whole archipelago has been designated as a Site of Special Scientific Interest within the Geological Conservation Review (Tanner et al., 2013). Strata dip systematically SE (Fig. 3e) and the lower boundary of the PAF is found on the north of Garbh Eileach and Dun Chonnuill (Spencer, 1971; Ali et al., 2017), but also within a raft (megaclast) within the "Great Breccia" lying within the PAF on A'Chuli. 
The carbonate unit underlying the PAF (Table 1) has been referred to as the Islay Limestone (Spencer, 1971). Since the term Islay Limestone has now been abandoned on Islay (BGS, 1997), it is illogical to continue to use this term on the Garvellachs. Although Arnaud and Fairchild (2011) used the term Lossit Limestone, in detail the lithologies differ from any of the members of that formation exposed on Islay and so must represent a different formation (mappable unit). Hence, the term Garbh Eileach Formation (GEF) is introduced here. Its type section is on NE Garbh Eileach (Figs. 3f, 8) and displays a mixed limestone-dolomite lower part beneath a dolomite upper part with increasing amounts of siliciclastic sand. The $70 \mathrm{~m}$-thick, $100 \%$ exposed GEF is not sub-divided into members, pending any future downward sampling by drilling, but is divided into numbered Beds (red numerals on Fig. 8) following Spencer (1971). The top part of the GEF has also been logged in three other locations (Fig. 9). Studies of lateral change have not been made lower in the GEF, although extensive exposures exist between the NE and $\mathrm{N}$ sections to do so (Fig. 3f).

Lateral changes in the basal part of the PAF are significant, especially the lateral thinning, local apparent downcutting, and dying out of the basal diamictite (D1, Figs. 9-11). In NE Garbh Eileach, D1 forms a single unit, with local lenses of stratified sediment, succeeded by a thin interval of dolomitic sediments sharply overlain by a laterally continuous diamictite (D2, Spencer, 1971). On Dun Chonnuill, the base of the PAF has been drawn at the base of the first diamictite, but D1 here also contains a series of disturbed dolomite beds with angular truncations. Other laterally continuous horizons in Fig. 9 include two sandstones in the upper part of the GEF. Bed 42 (Figs. 9-11) is capped with long-wavelength, straight-crested wave ripples, the most conspicuous rippled surface in the GEF. Bed 47 (Figs. 9-11) contains and overlies several closely spaced and locally stacked parallel-laminated sandstones. The presence of these Beds helps to confirm that the equivalent stratal surface to the base of D1 in NE Garbh Eileach is a thin gravelly horizon in N Garbh Eileach at $70 \mathrm{~m}$ on the log of Fig. 9 (Fig. 10d). The westernmost section, on $\mathrm{A}^{\prime}$ Chuli, is unusual in that a stratigraphic column straddling the GEF-PAF boundary has been constructed from folded and thrust strata in a stratigraphically higher megabreccia (D13, the Great Breccia). The presence of Beds 42, 47 and diamictite D2 (Fig. 11a) readily identifies the stratigraphic source for the raft, although the equivalent stratal surface to the base of D1 has only been approximately located (Fig. 9). The constraints imposed by visible lateral change (Fig. 10e) and correlation of Beds (Fig. 9) demonstrate that crystal pseudomorphs, interpreted later to be originally gypsum, occur not only in the GEF (Beds 28, 31 and 38, Fig. 8), but just below D2 in the two western sections (Fig. 9).

\subsection{Sedimentary evolution}

The lower half of the GEF consists of relatively pure carbonates with limestone more abundant than dolomite. Limestones are predominantly microspar (originally micrite), locally contain siliciclastic silt, and are commonly laminated by impurity content. Stromatolitic bioherms (Fig. 12a), dominated by limestone occur in Beds 7, 13 and 14. The best examples are all along the outcrop of Bed 7 between the NE and Garbh Eileach locations. The ovoid 0.5-3 m-scale buildups with internal 1-5 cm-wide domes, resemble the shallow subtidal forms found in the Bonahaven Formation that overlies the PAF (Spencer and Spencer, 1972; Fairchild, 1980, 1991). Like the Bonahaven rocks, wave action is demonstrated by wave-ripple lamination (Fig. 8) and graded laminae. Thinly interlaminated limestone and dolomite (Fig. 12b) is common in the interval between Beds 9b and 18, and at least a partly primary origin for the lamination is indicated by grading from slightly silty limestone to dolomicrite containing some clay. On the other hand, lensoid limestone structures within dolomite are also common (e.g. base of Fig. 12b) perhaps arising by concretionary cementation of limestone followed by partial dolomitization of areas outside concretions. Interlaminated rocks commonly bear small-scale polygons, $<1$ to $3 \mathrm{~cm}$ in diameter (Fig. 12c) in which dolomitic sediment infiltrates cracks in limestone. These polygons are not associated with intraclast formation as expected from desiccation cracks, implying they may have a sub-surface origin, possibly connected to loading stresses on early-cemented layers (cf. McMahon et al., 2016). On the other hand, discrete flake 
breccia beds are found locally (Fig. 12b), particularly in association with stromatolites (Fig. 8). Erosion of cemented flakes in a shallow subtidal environment by storm action (cf. Fairchild, 1980) is implied.

In Beds 21-27, the lithologies become dominantly fine-grained siliciclastics: mudstone, siltstone and very fine-grained sandstone, normally with a significant dolomite content. A motif of decimetre-scale alternations of more and less dolomitic strata appears locally (Fig. 12d). Strata are dominated by thin parallel laminae representing subtle changes in grain size, with local ripple crosslamination. The first occurrence of desiccation cracks and derived intraclasts is found in Bed 26 (Fig. 12e). The change in composition within this interval implies a subtle palaeogeographic shift permitting fluvially derived siliciclastic sediment to dominate the near-coastal zone.

From the top of Bed 27 ( $50 \mathrm{~m}$ level) upwards, the balance is tipped towards dolomite with siliciclastic impurities. Discrete, parallel-laminated medium-grained sandstone beds (1-50 $\mathrm{cm}$ thick) appear, the first example being Bed 29 (Fig. 12f) and they become more abundant upwards. Beds 42 and 47 were mentioned above in the context of being stratigraphic markers. The wave ripples in Bed 42 (Figs. 10f, 11e) have wavelength varying from $13 \mathrm{~cm}$ (NE Garbh Eileach) to $8 \mathrm{~cm}$ ( $A^{\prime}$ Chuli), which requires a significant wave fetch (Fairchild, 1980; Allen, 1984). Likewise, the stacked and locally strongly erosive sandstones of Beds 46 and 47 (Figs. 10c, 11f) imply an environment open to onshore transport of siliciclastic sediment during storms.

Conversely, Beds 27-38 (50-60 m) display pseudomorph structures. In Beds 28, 31, and 38 occur various horizons with biconvex crystals, $2-10 \mathrm{~cm}$ long, often forming stellate patterns (Fig. 14d$\mathrm{f}, \mathrm{h}$ ). An important observation (as in Spencer, 1971) is that the crystals are tabular and not columnar in morphology (Fig. 14e, f), which was confirmed during experimental etching of this sample. The crystals are silicified, dominantly megaquartz (Fig. 14g), but with local microquartz (chert), with subordinate calcite or ferroan dolomite, more so in the examples from Bed 38 which do not weather in relief (Fig. 14i). Crucially, 1-10 $\mu \mathrm{m}$ inclusions of anhydrite are present within the quartz, identifiable by their equant nature, square-sided terminations and bright high first-order polarization colour (Fig. 14h). Accordingly, the crystals can be confidently identified as originally gypsum, which is monoclinic and typically tabular, and which dehydrates to anhydrite during shallow burial. Isolated gypsum crystals (or roses) are common in subaerial modern environments such as arid tidal flats and sabkhas (Warren, 2006) and somewhat similar morphologies were found in siliciclastic tidal-flat deposits of the Dalradian Craignish Phyllites by Anderton (1975). An identical mode of preservation of anhydrite in gypsum pseudomorphs is also found in the Neoproterozoic Porsanger Formation of Norway (Tucker, 1976). Anhydrite inclusions are additionally located within wedge-shaped quartz-ferroan dolomite pseudomorphs at the top of Bed 27 (Fig. 14a, c). The structures display evidence of ptygmatic folding implying greater rigidity than the surrounding sediment during compaction, perhaps because they were already silicified. This example is interpreted as representing the deposition of evaporite within long-lived desiccation cracks on a supratidal surface in a semi-arid environment (cf. Alsharan and Kendall, 2003).

Several authors (Shearman and Smith, 1985; Johnston, 1995; Arnaud and Fairchild, 2011) refer to the possibility that pseudomorphs at this stratigraphic level are replacements of the coldwater polymorph ikaite $\left(\mathrm{CaCO}_{3} \cdot 6 \mathrm{H}_{2} \mathrm{O}\right)$ which is known to form radiating aggregates, e.g. the now calcitic glendonites associated with Gondwanan Upper Palaeozoic glaciation. However, only Johnston (1995) made primary observations to support this and he worked solely in the probable lateral equivalents of GEF at Glencolumbkille, Donegal. Inspection of the Donegal site in 2013 showed: 1) although there are some silicified structures that might represent pseudomorphs, they are not sufficiently well-shaped to be diagnostic and 2) Johnston (1995) was clearly describing not these structures, but calcareous flake breccias: hence his paper can be discounted. Recently, Fairchild et al. (2016) have described ikaite pseudomorphs from Neoproterozoic glacilacustrine environments and reviewed criteria for their recognition. The tabular morphology of the Garbh Eileach structures rules them out as ikaite pseudomorphs. One likely occurrence, in the Easdale 
Slates (Fig. 2), remains (Dempster and Jess, 2015), representing sub-surface crystal growth beneath a deeply frozen landscape during the later, Marinoan glaciation.

Further evidence of subaerial exposure in the upper GEF is implied by irregular erosion surfaces (Beds 38, 41, 44 and 47, Fig. 13a) and horizons of dolomite intraclasts (Beds 26, 35, 37 and 48). Their sparse distribution implies that emergence may have been relatively unusual (similar to the scoured dolomite sub-facies of the Bonahaven Formation, Fairchild, 1980). Another potential environmental indicator is provided by the Fe content of dolomite beds (typically 1-3 wt. \% Fe, Sawaki et al., 2010, Table S2), a proxy for which is their weathering colour. Although dependent on good-quality outcrops for comparison, Fig. 8 identifies Beds 39 and 44 as having lower Fe content. Bed 39 (Fig. 12g) lacks siliciclastic sediment layers, contrasting with overlying Bed 40 (Fig. 12h). Fairchild (1980) identified the high Fe content of coastal Dalradian pure dolomite as potentially conflicting with an oxygenated atmosphere, a riddle that can be resolved by the concept of the ferruginous ocean (e.g. Hood and Wallace, 2014). Derivation of ferrous iron from reducing seawater below a surface oxic layer seems likely, with transport provided during storm disturbances. Lower-Fe units, such as Bed 39 might therefore reflect isolation from marine flooding during storms. Overall, the absence of evidence for tidal activity in the GEF is notable by comparison with members 3 and 5 of the PAF (Arnaud, 2004) and overlying deposits (Fairchild, 1980; Anderton, 1976). Hence, the upper part of the GEF can be visualized as semi-arid to arid coastal mudflats, variably isolated from fluvial sediment sources, intermittently exposed, and subject to storm action.

A further important aspect of the upper GEF environment is provided by evidence for intermittent input of coarser sediment on suitably cleanly weathered outcrops and cut samples. The more obvious examples are identified on Figs. 8 and 9 as "scattered granules", although granules are rare and the bulk of this sediment is in the coarse- to very coarse-sand range. The stratigraphically lowest example documented is at $63 \mathrm{~m}$ in the A'Chuli raft (Fig. 11b-d). It displays exceptionally wellpreserved sedimentary textures. In thin section, the host sediment is observed to be a thinly laminated dolomite with ungraded sub-millimetre silty laminae. Minor soft-sediment disturbances such as gently folded and truncated laminae and faults are common. Coarser sediment grains include chert, dolomitic silt and quartz and are associated with penetration of laminae. An origin of these clasts by aeolian deflation is conceivable in an arid coastal environment, but is inconsistent with the degree of sedimentary deformation associated and the presence of a delicate silt clast. Instead, the clasts can be identified as dropstones and the disturbed nature of the host sediment is typical of those associated with ice rafting (Hambrey and Harland, 1981; Thomas and Connell, 1985; Benn and Evans, 2010). This phenomenon is intermittently recognized through the upper $7 \mathrm{~m}$ of the GEF, including up to D1 (Fig. 13b, c).

The PAF has been classically interpreted as a succession of subglacial diamictites with intervening shallow-marine sediments, plus evidence for ice-rafting at specific horizons (Spencer, 1971). Others have interpreted diamictites as ice-rafted (Eyles and Eyles, 1983) or mass flows (Arnaud and Eyles, 2006), whilst Benn and Prave (2006) identified new evidence for proglacial and subglacial deformation at some levels in the PAF. Some novel data bearing on these issues are discussed in Ali et al. (2017), but the depositional mechanisms of the diamictites are outside the scope of the current paper, as is the type of ice responsible for the ice-rafting. Neither do we discuss whether complex exposure surfaces such as that shown close to the GEF-PAF boundary (Fig. 13a) might reflect periglaciation; this will be the subject of further work. Accordingly, we have not detailed the internal structure or associated deformational structures. Instead our focus is on establishing the transitional nature of environmental change across the boundary from the GEF to the PAF.

Deposition of dolomitic sediments continues into strata defined above as lying within the PAF. In the Dun Chonnuill section, such beds separate diamictites and may be broken up and tilted (Fig. 13d, e), locally contain ice-rafted grains (Fig. 13f, g), and show evidence for subaerial erosion (Fig. 13h). At N Garbh Eileach, an ice-rafted horizon replaces D1 (Fig. 10d) and is succeeded by siltstones containing discrete channelled gravels (Fig. 10a). The glacigenic or non-glacigenic context 
of these deposits needs further clarification. However, more diagnostic is the succeeding laminated dolomicrite with stellate gypsum pseudomorphs (Fig. 10b) beneath D2, as seen in the GEF. The raft at $A^{\prime}$ Chuli also shows, in the PAF, parallel-laminated sandstones like those of the GEF (Fig. 10) and stellate pseudomorphs (Fig. 11g), seen in thin section to display exquisitely preserved laminated dolomite (Fig. 11h) with disruption probably related to gypsum crystal growth. The manner of preservation of $\mathrm{CaSO}_{4}$, as anhydrite inclusions in silica (Fig. 11i) is identical to that of the GEF.

Hence, our work clearly documents the presence of ice-rafting, within a shallow-water environment in which carbonate sediments were accumulating, at stratigraphic levels several metres before the first possible evidence for proximal glacial deposition. Secondly, we show that distinctive crystal pseudomorphs are after gypsum and point to semi-arid to arid climates. The lithostratigraphic reconstructions clearly demonstrate that these pseudomorphs are present before and after evidence for ice-rafting. Given the palaeomagnetic evidence that Scotland lay in the subtropics at $720 \mathrm{Ma}$ (Li et al., 2013), the conclusion is drawn that the Garbh Eileach location displays a transition to the icehouse climate of the early Cryogenian in an arid coastal setting.

\subsection{Carbon isotope stratigraphy}

Prave et al. (2009) first showed the presence of a negative carbon isotope anomaly in the Garbh Eileach section. A pre-glacial negative $\delta^{13} \mathrm{C}$ anomaly present in different continents has now been correlated and referred to as the "Islay anomaly" (Halverson et al., 2010; Halverson and ShieldsZhou, 2011; Cox et al.., 2016), but the time-relationships with the Scottish succession have not been demonstrated. Here we introduce the term Garvellach anomaly as a replacement for Islay anomaly. Sawaki et al. (2010) amplified the results of Prave et al. (2009), comparing the stratigraphic horizons directly with the Beds of Spencer (1971), and demonstrating that the succession also had low ${ }^{87} \mathrm{Sr} /{ }^{86} \mathrm{Sr}$ values of $0.7064-0.7066$. We have now greatly expanded the sampling for carbon isotopes and the isotope anomaly is revealed to have a remarkably smooth shape (Fig. 15). A primary origin for this trend is supported by the similarity of dolomite and calcite compositions at the same stratigraphic level. In the companion paper by Ali et al. (2017, their Fig. 5) we show that smooth variations in the composition of clasts in the lowest 12 diamictites of the PAF (data in Table S2) also occur.

Isotope cross-plots shown in Figure 16 include also those for clasts in the lowest 12 diamictites, which are plotted stratigraphically in Ali et al. (2017). The limestone data (Fig. 16a) illustrate a wide range of $\delta^{18} \mathrm{O}$ values for the GEF, but no isotopic covariation. This is important since models of post-depositional isotope exchange with a high- $\mathrm{CO}_{2}$ fluid to explain negative $\delta^{13} \mathrm{C}$ signatures, such as that for the Ediacaran Shuram-Wonoka anomaly proposed by Derry (2010), demonstrate strong co-linearity of data. Limestone clasts in the diamictites tend to have higher $\delta^{13} \mathrm{C}$ and $\delta^{18} \mathrm{O}$ values than the bedded limestones analyzed, but there is some overlap of the data fields. The simplest explanation for the difference in $\delta^{13} \mathrm{C}$ compositions is that the clasts were eroded from deeper stratigraphic levels than are now exposed on Garbh Eileach, an interpretation favoured by the smooth vertical variations in clast composition (Ali et al., 2017). The higher $\delta^{18} \mathrm{O}$ values of clasts than bedded strata implies that stabilization of the carbonate mineralogy to calcite took place at lower temperatures and hence shallower burial depths in the clasts. A deep burial stabilization for the limestones is consistent with absence of evidence for aragonite dissolution fabrics. Although meteoric diagenesis might have been expected in the GEF due to intermittent emergence in PAF times, the upper, presumably early-lithified dolomitic part of the formation could have acted as a permeability barrier.

The dolomite data from the GEF and lower PAF taken together (Fig. 16b) show a broad isotopic covariance, but when broken down into different spatial groups this disappears. Firstly, dolomite clasts in the diamictite have relatively high (weakly negative) $\delta^{18} \mathrm{O}$ compositions, consistent with limited isotope exchange. Most remarkably, the least negative values in the dataset are restricted to the $A^{\prime}$ Chuli dolomite raft and are comparable with typical values in unmetamorphosed peritidal dolomite (Fig. S8b). It is implied that dolomite components were relatively protected from 
isotope exchange in this situation. The bedded dolomite in the GEF and between the first two diamictites of the PAF display $\delta^{13} \mathrm{C}$ values consistent with their stratigraphic position and modal $\delta^{18} \mathrm{O}$ compositions of -6 to $-8 \%$, with a scatter to lower values. As discussed in more detail in the supplementary information, this can be attributed to variable O-isotope exchange during deep burial and metamorphism, during which C-isotope composition is buffered by the host rock. In conclusion, it appears that the carbon isotope profile defined by limestones and dolomites is internally consistent and provides a robust indication of the syndepositional carbon system.

\section{Offshore Garvellach geology}

Until recently, the offshore northwest extension of the Dalradian geology of the Garvellachs was thought to be largely concealed under an unconformity beneath continental deposits (?Silurian, Old Red Sandstone). However, a number of high-resolution multibeam echo-sounder surveys of the seabed of the Firth of Lorn have been carried out on behalf of the Maritime Coastguard Agency's (MCA) Civil Hydrography Programme. In particular, the INIS Hydro project (Ireland, Northern Ireland and Scotland Hydrographic Surveys) revealed submarine topography scoured by ice during Quaternary glaciation that demonstrated a broader seabed outcrop of Appin Group rocks in water depths of 10-90 m offshore from the Garvellachs (Howe et al., 2015; Dove et al., 2015). Furthermore, there is a consistent NE-SW strike in a broad region surrounding the Garvellachs, and probably a consistent, moderate dip angle. A cross-section running through Garbh Eileach (line A-B, Fig. 17a) indicates that $1.5 \mathrm{~km}$ of strata beneath the PAF should crop out on the seafloor before disappearing beneath the Old Red Sandstone cover to the NW.

An opportunity to attempt to core sites in the region arose during a British Geological Survey (BGS) cruise in July 2015 which was primarily to test new seabed drilling technology (BGS Rockdrill RD2). Sites were selected for Appin Group targets and two were drilled, although core recovery was limited to within the top $2 \mathrm{~m}$ of bedrock. Site $1\left(56^{\circ} 15.274^{\prime} \mathrm{N}, 5^{\circ} 44.274^{\prime} \mathrm{W}\right.$, water depth $543 \mathrm{~m}$ ) was chosen to lie stratigraphically close to the base of the exposed GEF. Site $4\left(56^{\circ} 15.395^{\prime} \mathrm{N}, 5^{\circ}\right.$ $47.072^{\prime} \mathrm{W}$, water depth $55 \mathrm{~m}$ ) lies on a ridge lying to the NW of a furrow, a further ridge and a deeper furrow. Reasoning that the furrows corresponded to major slate units in the Appin Group, this site was suggested to correspond to the Ballachulish Limestone.

The seabed was penetrated at two closely spaced locations at Site 1 . The drill at site $1 \mathrm{~A}$ penetrated $0.15 \mathrm{~m}$ into pale grey limestone, whereas at site $1 \mathrm{~B}$ core of similar limestone was recovered from depths of 2.14 to $2.56 \mathrm{~m}$ (Fig. 17b). The two least altered samples have $\delta^{13} \mathrm{C}$ of -3.3 to $-3.7 \%$ and $\delta^{18}$ O of -7.7 to $-9.8 \%$ (Table S2), like those at the base of the GEF within the Garvellach carbon isotope anomaly. $\mathrm{Sr}$ isotope values $(>0.7082$, Table $\mathrm{S} 2)$ are clearly not primary.

At site 4, black limestones were recovered at 0-1.14 $\mathrm{m}$ and 2.05 to $2.90 \mathrm{~m}$ depth. Lithologies were dominantly carbonate mudstone, with some thin beds of grainstone. Molar tooth structure was found at 0.90-0.96 m depth (Fig. 17c) cut by later calcite veins. Three sub-samples from different depths, including molar tooth calcite, showed a narrow range of $3.6-4.3 \%$ in $\delta^{13} \mathrm{C}$ and -8.7 to $-8.9 \%$ in $\delta^{18} \mathrm{O}$, whilst $\mathrm{Sr}$ isotope values of $>0.7076$ indicate secondary addition of ${ }^{87} \mathrm{Sr}$ (Table S2). The carbon isotope values contrast with those found on mainland sections of the Ballachulish Limestone. For example, at Spean Bridge Prave et al. (2009) found a progressive change in $\delta^{13} \mathrm{C}$ from -0.5 to $-7.0 \%$ over a stratigraphic distance of $90 \mathrm{~m}$. However, the range of $\delta^{13} \mathrm{C}$ and consistently low $\delta^{18} \mathrm{O}(-11.5$ to $-13.5 \%$ ) in this traverse would match the patterns (Figs. S8A) suspected to be due to metamorphic alteration by Skelton et al. (2015). A metamorphic origin for the carbon isotope anomaly provides an alternative explanation to the tentative correlation with the Bitter Springs anomaly by Prave et al. (2009). Since this anomaly is now dated at 788-812 Ma (Swanson-Hysell et al., 2015), this correlation would seem incompatible with similar metamorphic dates constraining the maximum age of Dalradian deposition (Stephenson et al., 2013). 
Subsequent drilling in the Mid-Atlantic has demonstrated the capability of the RD2 drilling technology to recover cores of up to $50 \mathrm{~m}$ in $1.5 \mathrm{~m}$ sections stored in a carousel on the sea bed. This provides a viable alternative to deep drilling onshore to recover an extensive Appin Group section from the Firth of Lorn in the future.

\section{Composite record}

\subsection{Strontium isotope evidence}

In this section, we consolidate the several previous publications on ${ }^{87} \mathrm{Sr} /{ }^{86} \mathrm{Sr}$ stratigraphy and add new analyses in the context of our improved lithostratigraphy. Comparative methods are detailed in the supplementary information and Table S5. In general, post-depositional processes tend to increase ${ }^{87} \mathrm{Sr} /{ }^{86} \mathrm{Sr}$ because of the addition of ${ }^{87} \mathrm{Sr}$ from radioactive decay of ${ }^{87} \mathrm{Rb}$. Rb tends to substitute for $\mathrm{K}$ and so this is an issue wherever $\mathrm{K}$-bearing silicates are present, ultimately releasing

${ }^{87} \mathrm{Sr}$ into interstitial fluids where it may be taken up during growth or recrystallization of carbonates during diagenesis. Excess ${ }^{87} \mathrm{Sr}$ may also arise by contact with radiogenic basinal fluids during burial. Even where samples were initially screened for suitability using geochemistry, as was the case for nearly all the samples in this study, some samples show significantly higher ${ }^{87} \mathrm{Sr} /{ }^{86} \mathrm{Sr}$ than others in the same stratigraphic unit, illustrating this problem.

A summary of results with best estimates per sample for ${ }^{87} \mathrm{Sr} /{ }^{86} \mathrm{Sr}$ is given in Fig. 18, illustrating the relationship between $\mathrm{Sr}$ isotope ratio and $\mathrm{Sr}$ content for each formation. Sr is plotted inversely since mixtures of different Sr sources will plot as straight lines in ${ }^{87} \mathrm{Sr} /{ }^{86} \mathrm{Sr}-1 / \mathrm{Sr}$ space. In general, high Sr content is expected to correspond to good preservation of the original marine signature and there is a broad covariation in Fig. 18 reflecting such a relationship. However, in the Kilslevan Member, a sample with $>2000$ ppm Sr (<0.0005 on x-axis) has higher ${ }^{87} \mathrm{Sr} /{ }^{86} \mathrm{Sr}(>0.7068)$ than samples with much lower Sr. Conversely, low ${ }^{87} \mathrm{Sr} /{ }^{86} \mathrm{Sr}(<0.7068)$ within the Lower Keills Member is recorded by a data point with $<500 \mathrm{ppm}$ ( $>0.002$ on axis). Low $\mathrm{Mn} / \mathrm{Sr}$ is also commonly used as a criterion: Fairchild et al. (2000) for example found that a ratio of $<0.2$ excluded all altered data (as well as some good data) from Tonian carbonates in NE Svalbard and NE Greenland. However, in the current dataset, $\mathrm{Mn} / \mathrm{Sr}$ also fails to be consistent as a discriminatory criterion (Fig. S5).

Another issue to be evaluated is whether different analytical methodologies can explain the variations in best estimate of ${ }^{87} \mathrm{Sr} /{ }^{86} \mathrm{Sr}$ within each stratigraphic unit. Given the present-day oceanic residence time of $\mathrm{Sr}$ of 4 million years, ${ }^{87} \mathrm{Sr} /{ }^{86} \mathrm{Sr}$ is expected to vary little within members. Thus Thomas et al. (2004) noted that the lower values that they had obtained in the Ballygrant Formation (Storakaig Limestone Member), when compared with those obtained by Brasier and Shields (2000), as plotted in Fig. 18, could be explained by the absence of a pre-leaching step in the protocol of the latter. However, the Rb concentrations of leachates obtained by Brasier and Shields (2000) were too low to require a correction to the $\mathrm{Sr}$ isotope value, so both sets of measurements may be equally valid analytically.

Sub-set Anderson (Table S3) of our new data utilizes the rigorous successive leaching protocol described by Liu et al. $(2013,2014)$. This protocol was developed to build on the results of Bailey et al. (2000) who examined the selectivity of rock components to attack by a solvent, and the kinetics of these reactions. The protocol involves two pre-leach steps in which the powdered sample is contacted with an ammonium acetate solution and 13 leach steps with acetic acid whose concentration is increased successively at the seventh and $13^{\text {th }}$ leach (details in Table S5). Most of the samples chosen for this study would be regarded as challenging: either dolomite, or limestone with a recrystallized appearance, from the upper part of the Keills Member that had not been studied for Sr isotopes previously. In general, the samples display gently declining or U-shaped ${ }^{87} \mathrm{Sr} /{ }^{86} \mathrm{Sr}$ curves with successive leaches (Fig 19a). The pre-leach steps yield higher Rb/Sr (Fig. 19b), attributable to weakly bound ions from the inter-layer sites of clay minerals. Fe and $\mathrm{Mn}$ are also high at this stage (Figs. S3 and S4). The lowest Sr isotope signature is typically reached in one of the later 
leaches and correspond also to low $\mathrm{Rb} / \mathrm{Sr}$. The final one or two leaches may show an increase in ${ }^{87} \mathrm{Sr} /{ }^{86} \mathrm{Sr}$ and $\mathrm{Rb} / \mathrm{Sr}$, probably representing attack on silicate phases, where present. Where a complete set of leachate analyses is available, the $\mathrm{Sr}$ and Ca yields (not presented) can be used to simulate what would have been the result with a conventional total dissolution, with or without a pre-leach. A total dissolution would result in values 0.00002 to 0.00014 higher, although the preleach step in these samples has very low yields and does not materially affect the result.

This technique, although time-consuming, should be optimal, compared with other techniques where there is a single-step dissolution, with or without a pre-leach, and would be recommended for samples relatively low in Sr. However, results for the two limestone samples from the lower Keills Member (samples 14A and 14B) are around 0.7068 and yet results on other samples using a simpler protocol yield values of between 0.7066 and 0.7067 . In each stratigraphic unit, there is a spread in high-Sr samples of 0.0002 to 0.0003 which therefore appear attributable to intrinsic differences in samples, rather than methodology. This then appears to represent a fundamental limitation on the precision with which ${ }^{87} \mathrm{Sr} /{ }^{86} \mathrm{Sr}$ may be recovered in these rocks.

The stratigraphic variation in ${ }^{87} \mathrm{Sr} /{ }^{86} \mathrm{Sr}$ is limited in the main limestone units on Islay, with best samples lying in the range 0.7066 to 0.7068 for the Ballygrant Formation, and Kilslevan and lower Keills Members. In the upper part of the Keills Member, the recrystallized limestones 045 and 046 (Fig 19a) yield highly radiogenic, secondary signatures, but much lower values are found in the dolomites, with three samples lying between 0.7069 and 0.7071 , although the former is a low outlier in leach S1 for sample LF014 (Fig. 19a).

Generally, primary Sr-isotope signatures are not recoverable from dolomite. This can arise because they are impure (Hickman and Wright, 1983) or form from post-depositional fluids (Derry, 2010). However, it should also be borne in mind that Neoproterozoic marine limestones are not primary either, but result from stabilization of initial metastable precipitates (Spence et al., 2016). The upper Keills Member dolomites are unusual in that they lack clay impurities, clearly formed penecontemporaneously, and have a high Sr content (cf. e.g. Veizer et al., 1978); thus they are much more suitable for $\mathrm{Sr}$ isotope analysis than most dolomites and conceivably their $\mathrm{Sr}$ isotope signatures could the original seawater composition. However, interpreting as a primary marine composition would imply a rise in $\mathrm{Sr}$ isotope ratios of 0.0002-0.0003 within a stratigraphic member,opposite to the subsequent trend in the GEF.

An alternative possibility is that the ${ }^{87} \mathrm{Sr} /{ }^{86} \mathrm{Sr}$ ratios in the dolomites represents a marine signal modified in coastal waters by additional ${ }^{87} \mathrm{Sr}$ from rivers draining silicate terrains. However, this is contradicted by evidence from modern fluvial systems and marine embayments. Canadian rivers, for example, display three orders of magnitude lower Sr concentration than seawater (Veizer, 1989) and studies of the modern Baltic imply that a upwards shift of ${ }^{87} \mathrm{Sr} /{ }^{86} \mathrm{Sr}$ of 0.0002 to 0.003 would require a mixed solution with $<5 \%$ seawater (Widerlund and Andersson, 2006) whereas the dolomites have (evaporative) marine oxygen isotope signatures.

Relatively high-Sr dolomites could provide useful chemostratigraphic information in Neoproterozoic successions where high-Sr limestones are absent and the multiple leach technique optimizes recovery of a less-altered signal. However, in the current context, where high-Sr limestones are present in the same member as the dolomites, the slightly higher dolomite ${ }^{87} \mathrm{Sr} /{ }^{86} \mathrm{Sr}$ ratios stand out as being somewhat altered.,

On the other hand, the fall to ${ }^{87} \mathrm{Sr} /{ }^{86} \mathrm{Sr}$ of $0.7064-0.7066$ in the GEF (Sawaki et al., 2010) can be regarded as an unequivocally marine signal and matches the lowest values obtained in other sections prior to the Sturtian glaciation in NE Greenland (Fairchild et al., 2000) and the Mackenzie Mountains of NW Canada (Rooney et al., 2014).

\subsection{Lithostratigraphic and chemostratigraphic synthesis (Fig. 20)}

We have demonstrated the lithological variety and sedimentological interest of the Keills Member at the Lossit section, previously studied chemostratigraphically by Brasier and Shields (2000), Prave et 
al. (2009) and Sawaki et al. (2010). Combining data with the equivalent section in the Keills-Persabus area, an overall regressive tendency is found, dominated by carbonates, but with specific intervals of siliciclastic sediments. Values of $\delta^{13} \mathrm{C}$ continue the gradual decline from values close to $+5 \%$ in the Ballygrant Formation through the Kilslevan and Keills Members of the Lossit Formation to values around $+2 \%$ o (Fig. 20). The steady Sr isotope values of $0.7066-0.7068$ are interrupted by an interval in the upper Keills Member where Sr-rich limestones are absent. Relatively Sr-rich, pure dolomites record values of 0.0769-0.7071, but which are not thought to be primary, as argued above. Previous workers recognized the erosional contact of the PAF at the Lossit section. Our new results clarify that a significant time gap, representing at least the period of formation of the Persabus Member must exist here.

The Garbh Eileach section of carbonates is agreed by all workers to be younger than the Lossit Formation carbonates of Islay and contains a distinct set of carbonate lithologies. For this reason, it is named as the Garbh Eileach Formation (GEF). Shallow shelfal limestones and dolomites are succeeded by silty and sandy dolomites showing more frequent evidence of emergence in a semi-arid climatic setting. Remarkably, there is overlap in the stratigraphic distribution of dolomite, some with gypsum pseudomorphs, and evidence for ice-rafting and even diamictite formation. Clearly the contact of the GEF and the PAF is an environmental transition. Given also the lowlatitude position of Scotland at this time (Li et al., 2013), the onset of glacial phenomena should be a true reflection of the onset of panglaciation.

The carbonates display two features of chemostratigraphic interest. The ${ }^{87} \mathrm{Sr} /{ }^{86} \mathrm{Sr}$ ratio reaches low values of 0.7064-0.7066. This feature has been found elsewhere and is now used in genetic models of glaciation related to the weathering of continental flood basalts (Cox et al., 2016). However, there are subtle discrepancies in the $\mathrm{Sr}$ and $\mathrm{C}$ isotope records on different continents which make it difficult to use the Sr record to define which region has the most complete pre-glacial record (Shields-Zhou et al., 2016).

The carbon isotope profile is distinctive and internally consistent. The use of the term Islay anomaly is discredited by the confusion about where the evidence is located, and by the use of the term chronostratigraphically. By defining the term Garvellach anomaly to replace Islay anomaly, we want to re-set this debate about correlation of anomalies. Given the transitional nature of the facies between the GEF and the PAF and the close proximity to the top of the Garvellach anomaly, it seems that the Garvellach anomaly must have post-dated an anomaly in Canadian sections that formed 1520 My prior to glaciation.

Bearing in mind the above discussion, the most promising level for correlation of the Argyll sections with others worldwide would seem to be within the strata of GEF, with its distinctive negative $\delta^{13} \mathrm{C}$ anomaly and low ${ }^{87} \mathrm{Sr} /{ }^{86} \mathrm{Sr}$ ratios. The top of the anomaly is just a few metres below the first diamictites of the PAF and it has been argued that there is an environmental transition towards glacial conditions at this level. These stratigraphic characteristics would seem to be optimal for definition of the Tonian-Cryogenian boundary and a level close to the cross-over from negative to positive $\delta^{13} \mathrm{C}$ compositions should be readily correlatable. If there were a GSSP defined in this section, it would be convenient to do so at the boundary of Beds 39 and 40 (Fig. 15) in the GEF (Grid reference NM 679 127).

\section{Recommendations}

The stratigraphic work of the Cryogenian sub-Commission is aimed at improving correlation, as well as identifying a GSSP. Whatever the eventual outcome of the considerations regarding the GSSP, it is useful to point out future research potential. A series of recommendations regarding the Argyll region are given below: 
1. The most distinctive stratigraphic point for correlation in the Scottish succession is in the Garbh Eileach section, at the cross-over of $\delta^{13} \mathrm{C}$ values from negative to positive, and just below an environmental transition to an ice-prone coastal environment (Figs. 15, 20).

2. Research priorities on Islay include: a) the documentation of the Persabus Member and mapping the lower boundary relationships of the PAF inland to the west, b) more detailed study of biotic phenomena in the Keills Member and c) onshore drilling to compensate for incomplete exposure of the Keills and Persabus Members.

3. Research priorities on the Garvellachs include: a) more detailed understanding of relationships at the base of the PAF and its lower part including distinguishing ordinary subaerial exposure phenomena from periglacial structures and $b$ ) understanding the depositional mechanisms for diamictites.

4. Research priorities on the Appin Group more generally include: a) searching for molar tooth structure and further distinctive sedimentary phenomena at other stratigraphic levels, b) carrying out stratigraphically controlled chemostratigraphic profiles in each of the limestone units, including evaluating the effects of potential metamorphic fluid alteration and c) (perhaps most importantly from the chemostratigraphic point of view) sea-floor sampling or, ideally, marine drilling, to probe the thick, uniformly dipping Appin Group succession to the NW of the Garvellachs.

5. The possibility of a GSSP being located in Scotland is handicapped by the absence of radiometric data on strata with a clear stratigraphic relationship to the Port Askaig Formation. Given the absence of documented contemporary igneous activity, further work on the Re-Os system should be a priority.

\section{Conclusions}

This study has confirmed and amplified the chemostratigraphic conclusions of previous workers (Prave et al., 2009; Sawaki et al., 2010) that a composite section can be produced of late Tonian (Appin Group) carbonates from the Isle of Islay and the Garvellach Islands which underlie Cryogenian glacial deposits of the PAF. On Islay, we have corrected previous correlations by new mapping and section measuring, clarifying the stratigraphic position of previous sampling. At the previously studied Lossit section, dolomitic facies at the top of the $290 \mathrm{~m}$-thick Keills Member of the Lossit Formation are overlain erosively by the PAF. The Keills member has a similar thickness of $4 \mathrm{~km}$ to the north, in the Keills-Persabus area, and is overlain by the poorly exposed mixed carbonate-siliciclastic Persabus Member, which awaits study. An expanded chemostratigraphic database shows smooth stratigraphic variations in $\delta^{13} \mathrm{C}$ for both limestone and dolomicrite strata, once veins and secondary dolomite phases with variable values are excluded. Although limestones show calcite replacement of metastable phases such as aragonite, and have variable $\delta^{18} \mathrm{O}$ values and degree of crystal coarsening due to deep burial and metamorphism, there is no covariation with $\delta^{13} \mathrm{C}$, and the $\delta^{13} \mathrm{C}$ values appear to reflect their original sedimentary values. Strontium-rich, oolitic, intraclastic and micritic limestones of the Ballygrant and Lossit Formations have ${ }^{87} \mathrm{Sr} /{ }^{86} \mathrm{Sr}$ of $0.7066-0.7069$ and $\delta^{13} \mathrm{C}$ values which decrease upwards towards zero.

Several carbonate facies types on Islay are documented for the first time. Molar-tooth structure, reflecting the early cementation of upwards and downwards-tapering fractures in stiff sediment, is locally well-developed in the lower part of the Keills Member of the Lossit Formation. This is important in supporting the Tonian age of the upper Appin Group since molar tooth structure is absent globally after the first Cryogenian glaciation. Additionally, complex wishbone-shaped limestone intraclasts, dolomite framestones and derived intraclasts with complex vesicular calcification structures are found in the Keills Member and may provide useful palaeobiological information. 
A gradational sedimentary top to the Appin Group is found on the Garvellach Islands where a perfectly exposed $70 \mathrm{~m}$ succession (GEF) passes from limestone-dominated, with ${ }^{87} \mathrm{Sr} /{ }^{86} \mathrm{Sr}$ of 0.7064 0.7066 and negative $\delta^{13} \mathrm{C}$ values, to sandy and silty dolomites with $\delta^{13} \mathrm{C}$ rising to weakly positive values, wave-generated structures and gypsum pseudomorphs. In the basal PAF, there is an interstratification of glacigenic beds with dolomite which display subaerial exposure surfaces and/or gypsum pseudomorphs. If the Tonian-Cryogenian GSSP were to be defined in Scotland, it could be placed in our NE Garbh Eileach section $9 \mathrm{~m}$ below the base of the PAF at the point where $\delta^{13} \mathrm{C}$ values become positive and $4 \mathrm{~m}$ below the first evidence for ice-rafted sediment.

The negative anomaly (values of -4 to $-7 \%$ ) in the GEF is here termed the Garvellach anomaly, replacing the term Islay anomaly. The latter is confusing because we and Skelton et al. (2015) have shown that primary negative $\delta^{13} \mathrm{C}$ valuesdo not occur on Islay; also the stratigraphic term "Islay Limestone" is obsolete. This anomaly has been correlated by others with a negative anomaly in Canadian sections dated at $>730 \mathrm{Ma}$. Howeverit it lies close below the transitional base to glacial deposits documented here, correlated with the Sturtian glaciation dated elsewhere to have begun at 716-717 Ma, hence implying that the Garvellach anomaly is younger.Thus, we have verified and amplified the chemostratigraphic understanding of the succession in western Scotland, and through demonstration of a transition to glacial conditions in a region reconstructed to have lain in the tropics, established its credentials as a world-class site for the Tonian-Cryogenian boundary.

\section{Acknowledgements}

IJF's initial work on this project in 1979 was supported by the University of Cambridge; in the period 2013-16, he was supported by NERC grant GR3/NE/H004963/1 and the University of Birmingham. MET thanks Team Tucker for field assistance (1979 Garvellachs, 1980 Islay) and the University of Newcastle upon Tyne for funding and facilities. Fieldwork in 2011 was supported by Harvard University's Department of Earth and Planetary Sciences and Origins of Life Institute, and by the NASA Astrobiology Institute. Offshore multibeam echo-sounder survey INIS Hydro was funded by the Special European Union Projects Board (SEUPB) as part of the Interreg IV programme 2011-2013. Thanks to BGS colleagues and the crew of NLV Pharos involved in the 2015 Firth of Lorn coring cruise. We thank Alasdair MacLachlan and family of Cullipool, Luing, for boat services in the Garvellach islands from 2011 to 2017 and the journal referees, including Tony Prave, for their constructive comments.

\section{Supplementary data}

Supplementary data associated with this article can be found, in the online version, at http://.

\section{References}

Ali, D.O., Spencer, A.M., Fairchild, I.J., Chew, K.J., Anderton, R., Levell, B.K., Hambrey, M.J., Dove, D., Le Heron, D.P. (Submitted February 2017). Indicators of relative completeness of the glacial record of the Port Askaig Formation, Garvellach Islands, Scotland. Precambrian Research.

Allen, P.A., 1984. Some guidelines in reconstructing ancient sea conditions from wave ripple marks. Marine Geology, 43, M59-M67.

Alsharan, A.S., Kendall, C.G.StC., 2003. Holocene coastal carbonates and evaporites of the southern Arabian Gulf and their ancient analogues. Earth-Science Reviews, 61, 191-243.

Anderson, R.P., Fairchild, I.J., Tosca, N.J., Knoll, A.H., 2013. Microstructures in metasedimentary rocks from the Neoproterozoic Bonahaven Formation, Scotland: Microconcretions, microtektites, or microfossils? Precambrian Research, 233, 59-72. 
Anderson, R.P., Tarhan, L.G., Cummings, K. E., Planavsky, N.J., Bjørnerud, M., 2016. Macroscopic structures in the $1.1 \mathrm{Ga}$ continental Copper Harbor Formation: Concretions or fossils? Palaios, 31, 327-338.

Anderton, R., 1975. Tidal flat and shallow marine sediments from the Craignish Phyllites, Middle Dalradian, Argyll, Scotland. Geological Magazine 112, 337-340.

Anderton, R., 1976. Tidal-shelf sedimentation: an example from the Scottish Dalradian. Sedimentology, 23, 429-458.

Anderton, R., 1985. Sedimentation and tectonics in the Scottish Dalradian. Scottish Journal of Geology, 21, 407-436.

Anderton, R., 1988. Dalradian slides and basin development: a radical interpretation of stratigraphy and structure in the SW and Central Highlands of Scotland. Journal of the Geological Society, London, 145, 669-678.

Antcliffe, J.B., Callow, R.H.T., Brasier, M.D., 2014. Giving the early fossil record of sponges a squeeze. Biological Reviews, 89, 972-1004.

Arnaud, E., 2004. Giant cross-beds in the Neoproterozoic Port Askaig Formation, Scotland: implications for snowball Earth. Sedimentary Geology, 165, 155-174.

Arnaud, E., Eyles, C., 2002. Catastrophic mass failure of a Neoproterozoic glacially influenced continental margin, the Great Breccia, Port Askaig Formation, Scotland. Sedimentary Geology, 151, 313-333.

Arnaud, E., Eyles, C., 2006. Neoproterozoic environmental change recorded in the Port Askaig Formation, Scotland: climatic and tectonic controls on sedimentation. Sedimentary Geology, 183, 99-124.

Arnaud, E., Fairchild, I.J. 2011 The Port Askaig Formation, Dalradian Supergroup, Scotland In: Arnaud, E., Halverson, G. P. \& Shields-Zhou, G. (eds) The Geological Record of Neoproterozoic glaciations. Geological Society of London, Memoir 36, 635-642.

Bailey, T.R., McArthur, J.M., Prince, H., Thirlwall, M.F., 2000. Dissolution methods for strontium isotope stratigraphy. Chemical Geology, 167, 313-319.

Benn, D.I., Prave, A.R., 2006. Subglacial and proglacial glacitectonic deformation in the Neoproterozoic Port Askaig Formation, Scotland. Geomorphology, 75, 266-280.

Benn, D.I., Evans, D.J.A., 2010. Glaciers and glaciation. $2^{\text {nd }}$ edn. Hodder Education, Oxford.

Brasier, M.D., Shields, G., 2000. Neoproterozoic chemostratigraphy and correlation of the Port Askaig glaciation, Dalradian Supergroup of Scotland. Journal of the Geological Society, London, 157, 909-914.

BGS (British Geological Survey), 1997. North Islay. Scotland Sheet 27. Solid and Drift Geology. 1:50000 Provisional Series, Keyworth, Nottingham.

Chew, D.M., Strachan, R.A., 2014. The Laurentian Caledonides of Scotland and Ireland. In: Corfu, F., Gasser, D. \& Chew, D. M. (eds) New Perspectives on the Caledonides of Scandinavia and Related Areas. Geological Society, London, Special Publication, 390, 45-91.

Cox, G. M., Halverson, G.P., Stevenson, R.K., Vokaty, M., Poirier, A., Kunzmann, M., Li, Z.-X., Denyszyn, S.W., Strauss, J.V., Macdonald, F.A. 2016. Continental flood basalt weathering as a trigger for Neoproterozoic Snowball Earth. Earth and Planetary Science Letters, 446, 89-99.

Dempster, T., Jess, S.A., 2015. Ikaite pseudomorphs in Neoproterozoic Dalradian slates record Earth's coldest metamorphism. Journal of the Geological Society, London, 172, 459-464.

Dempster, T.J., Rogers, G., Tanner, P.W.G., Bluck, B.J., Muir, R.J., Redwood, S.D., Ireland, T.R., Paterson, B.A., 2002. Timing of deposition, orogenesis and glaciation within the Dalradian rocks of Scotland: Constraints from U-Pb zircon ages. Journal of the Geological Society, London, 159, 83-94.

Derry, L.A., 2010. A burial diagenesis origin for the Ediacaran Shuram-Wonoka isotope anomaly. Earth and Planetary Science Letters, 294, 152-162. 
Dove, D., Arosio, R., Finlayson, A., Bradwell, T., Howe, J.A., 2015. Submarine glacial landforms record Late Pleistocene ice-sheet dynamics, Inner Hebrides, Scotland. Quaternary Science Reviews, 123, 76-90.

Eyles, N., Eyles, C.H., 1983. Glaciomarine model for upper Precambrian diamictites of the Port Askaig Formation, Scotland. Geology, 11, 692-696.

Fairchild, I.J., 1980. Sedimentation and origin of a late Precambrian 'dolomite' from Scotland. Journal of Sedimentary Petrology, 40, 423-446.

Fairchild, I.J., 1985. Petrography and carbonate chemistry of some Dalradian dolomitic metasediments: preservation of diagenetic textures. Journal of the Geological Society, 142, 167-185.

Fairchild, I.J. 1991 Itinerary II. Topmost Islay Limestone (Appin Group), Port Askaig and Bonahaven Formations (Argyll Group) Port Askaig area, Islay. In: The Late Precambrian Geology of the Scottish Highlands and Islands (ed. by C.J. Lister) Geologists Association Guide, London, p. 33-41.

Fairchild, I.J., Spiro, B. 1987. Petrological and isotopic implications of some contrasting Precambrian carbonates, NE Spitsbergen. Sedimentology, 34, 973-989.

Fairchild, I.J., Herrington, P.M., 1989. A tempestite-evaporite-stromatolite association (late Vendian, East Greenland): a shoreface-lagoon model. Precambrian Research, 43, 101-127.

Fairchild, I.J., Marshall, J.D., Bertrand-Sarfati, J., 1990. Stratigraphic shifts in carbon isotopes from Proterozoic stromatolitic carbonates (Mauritania): influences of primary mineralogy and diagenesis. American Journal of Science 290-A, 46-79.

Fairchild, I.J., Einsele, G., Song, T. 1997. Possible seismic origin of molar tooth structures in Neoproterozoic carbonate ramp deposits, north China. Sedimentology, 44, 611-636.

Fairchild, I.J., Spiro, B., Herrington, P.M., Song, T. 2000. Controls on Sr and C isotope compositions of Neoproterozoic Sr-rich limestones of E Greenland and N China, In: Grotzinger, J.P., James, N.P. (eds.) Carbonate Sedimentation and Diagenesis in the Evolving Precambrian World SEPM Special Publication 67, 297-313.

Fairchild, I.J., Fleming, E.J., Bao, H., Benn, D.I., Boomer, I., Dublyansky, Y.V., Halverson, G.P., Hambrey, M.J., Hendy, C., McMillan, E.A., Spötl, C., Stevenson, C.T.E., Wynn, P.M., 2016 Continental carbonate facies of a Neoproterozoic panglaciation, NE Svalbard. Sedimentology, 63, 253-306.

Halliday, A. N., Graham, C. M., Aftalion, M., Dymoke, P., 1989. The depositional age of the Dalradian Supergroup, $\mathrm{U}-\mathrm{Pb}$ and $\mathrm{Sm}-\mathrm{Nd}$ isotopic studies of the Tayvallich volcanics, Scotland. Journal of the Geological Society, London, 146, 3-6.

Halverson, G.P., 2006. A Neoproterozoic Chronology In: Xiao, S., Kaufman, A.J. (eds.), Neoproterozoic Geobiology and Paleobiology Springer, New York, pp. 231-271.

Halverson, G.P., Shields-Zhou, G., 2011. Chemostratigraphy and the Neoproterozoic glaciations. In: Arnaud, E., Halverson, G.P., Shields-Zhou, G. (eds), The Geological Record of Neoproterozoic Glaciations. Geological Society, London, Memoir 36, 51-66.

Halverson, G.P., Hoffman, P.F., Schrag, D.P., Maloof, A.C., Rice, A.H.N., 2005. Towards a Neoproterozoic composite carbon-isotope record. Geological Society of America Bulletin, 117, 1181-1207.

Halverson, G.P., Maloof, A.C., Schrag, D.P., Dudás, F.Ö., Hurtgen, M., 2007. Stratigraphy and geochemistry of a ca 800 Ma negatrive carbon isotope interval in northeastern Svalbard. Chemical Geology, 237, 5-27.

Halverson, G.P., Wade, B.P., Hurtgen, M.T., Barovich, K.M., 2010. Neoproterozoic chemostratigraphy. Precambrian Research, 182, 337-350.

Hambrey, M.J., Harland, W.B., 1981. Chapter 4. Criteria for the identification of glacigenic deposits. In: Hambrey, M.J., Harland, W.B. (eds.) Earth's pre-Pleistocene glacial record. Cambridge University Press, Cambridge, UK, p. 14-21. 
Harris, A.L., Haselock, P.J., Kennedy, M.J., Mendum, J.R., 1994. Chapter 6. The Dalradian Supergroup in Scotland, Shetland and Ireland. In: Gibbons, W., Harris, A.L. (eds.) A revised correlation of Precambrian rocks in the British Isles. Geological Society Special Report 22, 33-53.

Hickman, A.H., Wright, A.E., 1983. Geochemistry and chemostratigraphical correlation of slates, marbles and quartzites of the Appin Group, Argyll, Scotland. Transactions of the Royal Society of Edinburgh, 73, 251-278.

Hoffman, P.F., Halverson, G.P., Domack, E.W., Maloof, A.C., Swanson-Hysell, N.L., Cox, G.M., 2012. Cryogenian glaciations on the southern tropical paleomargin of Laurentia (NE Svalbard and East Greenland), and a primary origin for the upper Russ $\varnothing$ ya carbon isotope excursion. Precambrian Research, 206-207, 137-158.

Hoffman, P.F., Abbot, D.S., Ashkenazy, Y., Benn, D.I., Cohen, P.A., Cox, G.M., Creveling, J.R., Donnadieu, Y., Erwin, D.H., Fairchild, I.J., Ferreira, D., Goodman, J.C., Halverson, G.P., Jansen, M.F., Le Hir, G., Love, G.D., Macdonald, F.A., Maloof, A.C., Ramstein, G., Rose, B.E.J., Rose, C.V., Tziperman, E., Voigt, A. and Warren, S.G., 2017. Climate dynamics of Snowball Earth and Cryogenian geology-geobiology. Science Advances (in press)

Hood, A.V.S., Wallace, M.W., 2014. Marine cements reveal the structure of an anoxic, ferruginous Neoproterozoic ocean. Journal of the Geological Society, London, 171, 741-744.

Howe, J.A., Anderton, R.A., Arosio, R., Dove, D., Bradwell, T., Crump, P., Cooper, R. and Cocuccio, A., 2015 (for 2014). The sea-bed geomorphology and geological structure of the Firth of Lorn, western Scotland, UK, as revealed by a multibeam echo-sounder survey. Earth and Environmental Science Transactions of the Royal Society of Edinburgh, 105, 273-284.

Johnston, J.D., 1995. Pseudomorphs after ikaite in a glaciomarine sequence in the Dalradian of Donegal, Ireland. Scottish Journal of Geology, 31, 3-9.

Knoll, A.H., 2011. The multiple origins of multicellularity. Annual Review of Earth and Planetary Sciences, 39, 217-239.

Knoll, A.H., Swett, K., 1990. Carbonate deposition during the Late Proterozoic Era: an example from Spitsbergen. American Journal of Science, 290-A, 104-132.

Knoll, A.H., Fairchild, I.J., Swett, K. 1993. Calcified microbes in Neoproterozoic carbonates: implications for our understanding of the Proterozoic/Cambrian transition. Palaios, 8, 512525.

Knoll, A.H., Walter, M.R., Narbonne, G.M., Christie-Blick, N., 2006. The Ediacaran Period: a new addition to the geologic time scale. Lethaia, 39, 13-30.

Kuang, H.-W., 2014 Review of molar tooth structure research. Journal of Palaeogeography, 3, 359383.

Lan, Z., Li, X., Zhu, M., Chen, Z.-Q., Zhang, Q., Li, Q., Lu, D., Liu, Y., Tang, G., 2014. A rapid and synchronous initiation of the widespread Cryogenian glaciations. Precambrian Research, 255, 401-411.

Li, Z.-X., Evans, D.A.D., Halverson, G.P., 2013. Neoproterozoic glaciations in a revised global palaeogeography from the breakup of Rodinia to the assembly of Gondwanaland. Sedimentary Geology, 294, 219-232.

Liu, C., Wang, Z., Raub, T.D., 2013. Geochemical constraints on the origin of Marinoan cap dolostones from Nuccaleena Formation, South Australia. Chemical Geology, 351, 95-104.

Liu, C., Wang, Z., Raub, T.D., Macdonald, F.A., 2014. Neoproterozoic cap-dolostone deposition in stratified glacial meltwater plume. Earth and Planetary Science Letters, 404, 22-32.

Macdonald, F.A., Schmitz, M.D., Crowley, J.L., Roots, C.F., Jones, D.S., Maloof, A.C., Strauss, J.V., Cohen, P.A., Johnston, D.T., Schrag, D.P., 2010. Calibrating the Cryogenian. Science, 327, 1241-1243.

Maloof, A.C., Rose, C.V., Beach, R., Samuels, B.M., Calmet, C.C., Erwin, D.H., Poirier, G.R., Yao, N., Simons, F.J., 2010. Possible animal-body fossils in pre-Marinoan limestones from South Australia. Nature Geoscience, 9, 653-659. 
McCay, G.A., Prave, A.R., Alsop, G.I., Fallick, A.E., 2006. Glacial trinity: Neoproterozoic Earth history within the British-Irish Caledonides. Geology, 34, 909-912.

McMahon, S., Hood, A. van S., Mclroy, D., 2016. The origin and occurrence of subaqueous sedimentary cracks. In: Brasier, A.T., Mcllroy, D. and McLoughlin, N. (eds) Earth System Evolution and Early Life: a Celebration of the Work of Martin Brasier, Geological Society Special Publication, 448, doi: 10.1144/SP448.15 (in press).

Noble, S.R., Hyslop, E.K., Highton, A.J., 1996. High precision U-Pb monazite geochronology of the c. $806 \mathrm{Ma}$ Grampian Slide and the implications for the evolution of the Central Highlands. Journal of the Geological Society, London, 153, 511-514.

Parnell J, Baron M, Davidson M, Elmore D, Engel M., 2000. Dolomitic breccia veins as evidence for extension and fluid flow in the Dalradian of Argyll. Geological Magazine, 137, 447-462.

Prave, A.R., Fallick, A.E., Thomas, C.W., Graham, C.M., 2009. A composite C-isotope profile for the Neoproterozoic Dalradian Supergroup of Scotland and Ireland. Journal of the Geological Society, London, 166, 845-857.

Rast, N., Litherland, M., 1970. The correlation of the Ballachulish and Perthshire (Islay) Dalradian successions. Geological Magazine, 107, 259-272.

Rooney, A.D., Chew, D.M., Selby, D., 2011. Re-Os geochronology of the Neoproterozoic- Cambrian Dalradian Supergroup of Scotland and Ireland: Implications for Neoproterozoic stratigraphy, glaciation and Re-Os systematics. Precambrian Research, 185, 202-214.

Rooney, A.D., Macdonald, F.A., Strauss, J.V., Dudás, F.O., Hallmann, C., Selby, D., 2014. Re-Os geochronology and coupled Os-Sr isotope constraints on the Sturtian snowball Earth. Proceedings of the National Academy of Sciences, 111, 51-56.

Rooney, A.D., Strauss, J.V., Brandon, A.D., Macdonald, F.A., 2015. A Cryogenian chronology: Two

long-lasting synchronous Neoproterozoic glaciations. Geology, 43, 459-462.

Sawaki, Y., Kawai, T., Shibuya, T., Tahata, M., Omori, S., Komiya, T., Yoshida, N., Hirata, T., Ohno, T., Windley, B.F., Maruyama, S., $2010 .{ }^{87} \mathrm{Sr} /{ }^{86} \mathrm{Sr}$ chemostratigraphy of Neoproterozoic Dalradian carbonates below the Port Askaig Glaciogenic Formation, Scotland. Precambrian Research, 179, 150-164.

Shearman, D.J., Smith, A.J., 1985. Ikaite, the parent mineral of jarrowite-type pseudomorphs. Proceedings of the Geologists Association, 96, 305-314.

Shields, G.A. 2002. 'Molar-tooth microspar': a chemical explanation for its disappearance 750 Ma. Terra Nova, 14, 108-113.

Shields-Zhou, G.A., Porter, S., Halverson, G.P., 2016. A new rock-based definition for the Cryogenian Period. Episodes, 39, 3-8.

Skelton, A. D. L., Graham, C. M., Bickle, M. J., 1995. Lithological and structural controls on regional 3D fluid flow patterns during greenschist facies metamorphism of the Dalradian of the SW Scottish Highlands. Journal of Petrology, 36, 563-586.

Skelton, A., Lewerentz, A., Kleine, B., Webster, D., Pitcairn, I., 2015. Structural channelling of metamorphic fluids on Islay, Scotland: Implications for Paleoclimatic reconstruction. Journal of Petrology, 56, 2145-2172.

Smith, A.G., 2016. A review of molar-tooth structures with some speculations on their origin. In: MacLean, J.S. and Sears, J.W. (eds.) Belt Basin: Window to Mesoproterozoic Earth. Geological Society of America Special Paper, 522, 71-99.

Smith, M., Robertson, S., Rollin, K. E. 1999. Rift basin architecture and stratigraphical implications for basement-cover relationships in the Neoproterozoic Grampian Group of the Scottish Caledonides. Journal of the Geological Society, London, 156, 1163-1173.

Spence, G.H., Le Heron, D.P., Fairchild, I.J., 2016. Sedimentological Perspectives on Climatic, Atmospheric and Environmental Change in the Neoproterozoic Era. Sedimentology, 63, 253306.

Spencer, A.M., 1971. Late Pre-Cambrian Glaciation in Scotland. Geological Society, London, Memoirs, 6. 
Spencer, A.M., Spencer, M.O., 1972. The late Precambrian/Lower Cambrian Bonahaven Dolomite of Islay and its stromatolites. Scottish Journal of Geology, 8, 269-282.

Stephenson, D., Mendum, J.R., Fettes, D.J., Leslie, A.G., 2013. The Dalradian rocks of Scotland: an introduction. Proceedings of the Geologists Association, 124, 3-82.

Strauss, J,.V., Rooney, A.D., Macdonald, F.A., Brandon, A.D., Knoll, A.H., 2014. 740 Ma vase-shaped miocrofossils from Yukon, Canada: Implications for Neoproterozoic chronology and biostratigraphy. Geology, 42, 659-662.

Swanson-Hysell, N.L., Maloof, A.C., Condon, D.J., Jenkin, G.R.T., Alene, M., Tremblay, M.M. Tesema, T., Rooney, A.D., Haileab, B., 2015. Stratigraphy and geochronology of the Tambien Group, Ethiopia: Evidence for globally synchronous carbon isotope change in the Neoproterozoic. Geology, 43, 323-326.

Tanner, P.W.G., Bendall, C.A., Pickett, E.A., Roberts, J.L., Treagus, J.E., Stephenson, D., 2013. The Dalradian rocks of the south-west Grampian Highlands of Scotland. Proceedings of the Geologists Association, 124, 83-147,

Thomas, C.W., 1989. Application of geochemistry to the stratigraphic correlation of Appin and Argyll Group carbonate rocks from the Dalradian of northeast Scotland. Journal of the Geological Society, London, 146, 631-647.

Thomas, C.W., Graham, C.M., Ellam, R.M., Fallick, A.E., $2004 .{ }^{87} \mathrm{Sr} /{ }^{86} \mathrm{Sr}$ chemostratigraphy of Neoproterozoic Dalradian limestones of Scotland and Ireland: constraints on depositional ages and time scales. Journal of the Geological Society, London, 161, 229-242.

Thomas, G.S.P, Connell, R.J., 1985. Iceberg drop, dump and grounding structures from Pleistocene glaciolacustrine sediments, Scotland. Journal of Sedimentary Petrology, 55, 243-249.

Tucker, M.E., 1976. Replaced evaporites from late Precambrian of Finnmark Norway. Sedimentary Geology, 16, 193-204.

Tucker, M.E., 1983. Diagenesis, geochemistry, and origin of a Precambrian dolomite: the Beck Spring Dolomite of eastern California. Journal of Sedimentary Research, 53, 1097-1119.

Veizer, J., 1989. Strontium isotopes in seawater through time. Annual Review of Earth and Planetary Sciences, 17, 141-167.

Veizer, J., Lemieux, J., Jones, B., Gibling, M.R., Savelle, J., 1978. Paleosalinity and dolomitization of a Lower Paleozoic carbonate sequence, Somerset and Prince of Wales Islands, Arctic Canada. Canadian Journal of Earth Sciences, 15, 1448-1461.

Wallace, M.W., Hood, A.V.S., Woon, E.M.S., Hoffmann, K.H., Reed, C.P., 2014. Enigmatic chambered structures in Cryogenian reefs: the oldest sponge-grade organisms? Precambrian Research, 255, 109-123.

Warren, J.K., 2006. Evaporites; Sediments, Resources and Hydrocarbons. Berlin, Springer-Verlag.

Widerlund, A., Andersson, P.S., 2006. Strontium isotopic composition of modern and Holocene mollusc shells as a palaeosalinity indicator for the Baltic Sea. Chemical Geology, 232, 54-66.

Wilkinson, S.B., 1907 The Geology of Islay. Memoir of the Geological Survey of Scotland. Available at: https://ia800206.us.archive.org/21/items/cu31924003986498/cu31924003986498.pdf

Wright, A.E., 1988. The Appin Group. In: Winchester, J.A. (ed.) Later Proterozoic Stratigraphy of the Northern Atlantic Regions. London: Blackie, pp. 177-199.

Zhuravleva, Z.A., 1964. Riphean and Lower Cambrian oncolithes and catagraphs of Siberia and their stratigraphic importance. Transactions of the Academy of Sciences of the USSR, Geological Institute, 114, $70 \mathrm{pp}$ (in Russian). 
Figure 1. Location maps. a. Outcrop belt of the Dalradian Supergroup with location of main PAF exposures. b. Argyll region showing location of Islay and the Garvellachs. On Islay, PA is the village of Port Askaig, IA is the Islay Anticline (an en-echelon anticlinorium), $\mathrm{K}$ is the Keills-Persabus area (Fig. 3a), $\mathrm{L}$ is the Lossit area (Fig. 3b) and $\mathrm{O}$ is the Mull of Oa. The Garvellachs (enlarged in Figs. 3c, d) lie within the Firth of Lorn.

Figure 2. a. to e. Synthesis of the stratigraphy of the Dalradian Supergroup (updated from Sawaki et al., 2010). a. generalized stratigraphic profile. Nomenclature and indicative thicknesses are from Stephenson et al. (2013), but are laterally variable since depocentres migrated with time (Anderton, 1988). The older age constraint shown on the lithostratigraphic column is from deformed Moinian rocks tectonically underlying the Grampian Group (Noble et al. 1996) and the younger constraint is from syndepositional volcanic rocks at the top of the Argyll Group (Halliday et al. 1989; Dempster et al. 2002). b. Sr concentration, c. $\mathrm{Mn} / \mathrm{Sr}$ ratio, d. $\delta^{13} \mathrm{C}$ data, e. ${ }^{87} \mathrm{Sr} /{ }^{86} \mathrm{Sr}$ data. f. Global compilation of Sr isotope data from limestones (from Cox et al., 2016); note vertical scale is time. Age constraints on the beginning and end of the Sturtian glaciation and the end of the Marinoan glaciation are from Rooney et al. (2015). In b. to e. the Dalradian chemical data are from carbonate rocks and the stratigraphic intervals are expanded in places as shown by the dashed lines.

Figure 3. Locality maps of Islay and the Garvellachs. a. Preliminary map of Keills-Persabus area. b, c. Map and cross-section of Lossit area, slightly simplified from unpublished original at 1:2500 scale. The edge of the Jura Quartzite on the east side of the area is defined by a fault named the Beinn Bhan thrust. d. Legend of a. to c. e. Locations and summary geology of eastern part of Garvellach island chain including stars to indicate location of logged sections of Fig. 9 and box to show location of map g. f. stratigraphic key to map g. g. enlarged map of parts of Dun Chonnuill and Garbh Eileach, Garvellach Islands with stratigraphic labels drawn on directly (redrawn from Spencer, 1971; compare with logs in Figs. 8 and 9). Diamictites 1 and 2 belong within member 1 of the PAF; higher parts of the PAF not shown. Kilometre grid shown on $\mathbf{a}$ and $\mathbf{b}$ and $0.1 \mathrm{~km}$ grid on $\mathbf{f}$.; grid references have the prefix NR on Islay and NM on the Garvellachs.

Figure 4. Stratigraphy of the Islay sections (see Fig. 8 for key). The two left-hand columns illustrate the measured stratigraphic sections of the Keills Member of the Lossit Formation in the Lossit area and Keills-Persabus area (located in Fig. 3a, b). The right-hand column is the carbon isotope profile from limestones and dolomicrites (see section 4.3 for discussion). Zero corresponds to the base of the Keills Member. I to IV refer to lithologically similar levels correlated between the two sections. Brown letters (5a...6i) refer to the stratigraphic location of photographs in Figures 5 and 6.

Figure 5. Facies of the lower part of the Keills Member. a. Grainstone with dolomitized grains in limestone matrix. Stratigraphic level 5 m, location 41074 64092, cm-scale bars. b. Limestone thin section displaying micritic intraclasts with complex embayments suggestive of a chambered structure. Stratigraphic level 9.8 m, location 41757 64543. c. Polished oolitic limestone surface stained with Alizarin Red S exhibiting variable replacement by dolomicrospar (unstained).

Stratigraphic level $8.6 \mathrm{~m}$, location 41174 64534. d. Thin section of oolitic limestone with contrasting diagenesis: in upper half, ooids are calcitized and uncompacted whereas in the lower half, partly dolomitized ooids are strongly compacted because of aragonite dissolution. Stratigraphic level $97 \mathrm{~m}$, location 42075 689815. e. Stromatolitic domes forming part of bioherm structure. Stratigraphic level $161 \mathrm{~m}$, location, 42015 69024, cm scale. f. Molar tooth structure in plan view exhibiting separate, crudely aligned crack-fills. Stratigraphic level 4 m, location 41317 64392, mm scale to right. g. Cut and polished hand specimen showing surface perpendicular to cleavage towards which molar tooth crack-fills (pale) are rotated by tectonic deformation ( $\mathrm{mm}$-scale to right). Stratigraphic level $7 \mathrm{~m}$, location 41928 68429. h. Molar tooth structure in plan displaying crudely polygonal network of crack-fills (hammer shaft is $35 \mathrm{~cm}$ long). Same position and location as f. i. Profile of molar tooth 
crack-fills (pale) on weathered surface approximately parallel to cleavage; bedding trace is subhorizontal in image. Stratigraphic position $43 \mathrm{~m}$, location 41925 68581, mm scale markings at top. j. Thin section of molar tooth limestone displaying laminated carbonaceous microspar matrix (ma), microspar molar tooth cement filling molar tooth cracks $(\mathrm{mt})$ and post-tectonic saddle dolospar vein (v). Tectonic calcite veins (thin white zones) cut molar tooth cements but are truncated by the dolospar vein. Stratigraphic position 8 m, location 4136064375.

Figure 6. Facies of the upper part of the Keills Member; field scales have cm markings. a. Quartzcemented quartzose sandstone with gutter cast overlying mudrock. Stratigraphic height $179 \mathrm{~m}$, location 41536 64684. b. Parallel-laminated sandstone with strongly erosional base within mudrock. Stratigraphic height $190 \mathrm{~m}$, location 41467 64719. c. Dolomite with silicified nodule whose morphology is consistent with original anhydrite. Stratigraphic position $278 \mathrm{~m}$, location 41866 69166. d. Intraclastic dolomite with cross-stratification in different directions (highlighted by yellow dashed lines) with mounded top suspected to be microbial in origin. Stratigraphic position $268.3 \mathrm{~m}$, location 4126164722 . e. Photomicrograph of complex dolomite intraclast with calcified zones defining vesicular structure within broader envelopes. Stratigraphic position 272 m, location 41453 64849. f. Sawn and polished surface of dolomite (microbial facies) with complex mottled microstructure with dark calcified areas within cemented zones, and scattered siliciclastic sand. Stratigraphic position $268.4 \mathrm{~m}$, location 41261 64722. g. Photomicrograph of dolomite (microbial facies) containing siliciclastic coarse silt laminae between cryptic zones containing variably laterally continuous calcified zones. Stratigraphic position 270.75 m, location 4125364723 . h. Contact between top of Keills Member, with stromatolitic dome (lower left) laterally adjacent to coarse intraclastic facies, both erosively overlain by conglomerate of dolomite fragments with sandy matrix (basal PAF). Stratigraphic position $289 \mathrm{~m}$, location 41464 64881. i. Dolomicrite with stylolitic boundary over intraclastic dolomite. Stratigraphic position 274.5 m, location 4145564850.

Figure 7. Cross-plot of stable isotope data from the Keills and Kilslevan Members. The blue dashed line is a regression fit to the Keills Member limestone data $\left(\delta^{13} \mathrm{C}=0.146^{*} \delta^{18} \mathrm{O}+3.42, \mathrm{r}^{2}=0.19\right)$. Apart from this weak relationship, there is no covariation of the delta values. The limestone and dolomicrite sample types appear to be close to the $\delta^{13} \mathrm{C}$ values of the original marine precipitates and hence are retained for use in chemostratigraphy. Other categories are not.

Figure 8 Stratigraphy of the NE Garbh Eileach section. The system of numbered "beds" (red numerals) was originally introduced by Spencer (1971). Lower Fe content of beds 39 and 44 is indicated by a different shade, mimicking their weathered colour. Brown letters refer to the stratigraphic location of photographs in Figures 12 to 14.

Figure 9. Stratigraphic profiles around the boundary of the GEF and PAF; locations shown on Fig. 3e and $3 \mathrm{~g}$ and key to logs on Fig. 8. An additional diagram to show lateral variations in N Garbh Eileach is included as part of Fig. 10. Brown letters refer to the stratigraphic location of photographs in Figures 10, 11 and 13.

Figure 10. Field photographs and lateral changes around the base of the PAF, N Garbh Eileach (log in Fig. 9). a. Series of channelled sandy conglomerates (labelled 1, 2, 3), depicted as lying on foresets in diagram e. Conglomerates include tabular dolomite intraclasts; $75 \mathrm{~m}$ level. b. Stellate gypsum pseudomorphs on bedding surface in dolomite at $77 \mathrm{~m}$ level. c. Beds 46 and 47 of the GEF displaying a series of discrete sandstones (labelled 1 to 5 ) with internal parallel to undulatory lamination. Bed bases are erosional, most markedly down-cutting sub-vertically where arrowed. Bed form is also variably distorted by tectonic deformation.. Sandstones 4 and 5 amalgamate to define Bed 47 . Sandstone 5 is intraclastic at its base and fines up to dolomite which has an eroded top with dolomite intraclasts (not shown). d. Outsized crystalline clast which lies along a decimetre-scale 
horizon of inferred ice-rafted sandy and gravelly sediment, $70 \mathrm{~m}$. e. Diagram from Spencer (1971) illustrating lateral changes in N Garbh Eileach and a comparison with the section in NE Garbh Eileach. For "mixtite", read "diamictite". The stratigraphic log in Fig. 9 is a composite of the two purple vertical lines. Location of photographs a-d is shown. f. Marker wave-rippled horizon at the top of bed 42, also seen in NE Garbh Eileach and in the Great Breccia raft at A'Chuli (Fig. 11e).

Figure 11. Map and field photographs of sediment raft within the Great Breccia of A'Chuli that was derived from sediments straddling the GEF-PAF boundary (Fig. 9). General location is shown by a star on $A^{\prime}$ Chuli on Fig. 3e. a. Map produced on low-level aerial photograph of a sub-horizontal outcrop (wave-cut platform) depicting the raft (megaclast) which has a folded and thrust core. The log shown in Fig. 9 has been reconstructed from the lines of traverse shown. b. Whole thin section ( $63 \mathrm{~m}$ level) illustrating finely laminated dolomitic siltstone with scattered coarse sand to granules, inferred to have been ice-rafted. Minor syn-sedimentary folds and faults common (e.g. fault zone arrowed). Boxed area corresponds to siltstone clast of photograph c. c. Siltstone clast, inferred to have been ice-rafted (see b). d. Field appearance of dolomite with scattered coarse sand, inferred to have been ice-rafted at $63 \mathrm{~m}$ level (equivalent to Beds 43/44); $\mathrm{cm}$-scale. e. Wave-rippled top of sandstone marker Bed 42. f. Marker Bed 47 dolomitic sandstone with prominent parallel lamination and underlain by three other thin sandstone beds. This bed, together with Bed 42 (Fig. 11d) facilitates correlation across thrust slices within the raft. $\mathrm{g}$. Dolomite bedding surface with stellate gypsum pseudomorphs (76 $\mathrm{m}$ level). $\mathbf{h}$. Thin section of dolomite from level of photograph $\mathbf{g}$ with silty laminae displaying disruption. White areas are silicified gypsum pseudomorphs. i. Photomicrograph from silicified pseudomorph in $\mathbf{h}$ illustrating quartz crystals with bright, $<10 \mu \mathrm{m}$ inclusions of anhydrite.

Figure 12 Field photographs of the lower GEF from NE Garbh Eileach up to the proposed TonianCryogenian boundary. a. Bed 7, part of stromatolite bioherm, dominantly composed of limestone with laminae marked by dolomite. Hammer has $5 \mathrm{~cm}$ scale markings. b. Bed 11, carbonate laminites composed of limestone (blue-grey) and dolomite (buff); $\mathrm{cm}$ scale markings. Limestone is more lenticular near the base and a $4 \mathrm{~cm}$-thick flake breccia occurs just below centre. Lineations upper right to lower left are silty dolomite crack-fills rotated towards the plane of flattening during tectonic deformation. c. Bed 11, polygonal cracks in limestone with dolomitic fills; $\mathrm{cm}$ scale markings. d. Bed 21, alternations of dolomite and cleaved muddy dolomite; notebook is $19 \mathrm{~cm}$ long. e. Bed 26, lowest horizon with conventional desiccation cracks and intraclasts, $\mathrm{cm}$ scale markings. View is looking down on series of close-spaced bedding surfaces with, at different levels, dolomite separated by sandy crack-fills, and dolomite intraclasts. f. Bed 29, lowest horizon with distinct bed of parallellaminated medium-grained sandstone. Thinner sandstone beds alternate with fine-grained dolomite above and below the coarser sandstone. Notebook is $19 \mathrm{~cm}$ long. g. Bed 39, fine-grained, laminated dolomite with diverse quartz veins. Pale-coloured weathering identifies lower iron content than most GEF dolomites. The upper limit of this bed is proposed as the Tonian-Cryogenian boundary. Notebook is $19 \mathrm{~cm}$ long. h. Bed 40, laminated dolomitic siltstones. Upper scale on bar is in $\mathrm{cm}$.

Figure 13. The upper GEF and lowermost PAF from NE Garbh Eileach (a-c) and Dun Chonnuill (d-h). a. Upper contact of dolomite Bed 47b with sandy dolomitic breccia of Bed 48a. This is interpreted as a subaerial surface and may provide evidence for periglacial conditions. Centimetre scale markings. $\mathbf{b}$. Bed 48b, illustrating fine-grained dolomite with scattered very-coarse grained sand and granules, with a concentrated layer at the base. $\mathrm{Cm}$-scale markings $\mathrm{c}$. Top of Bed 48b illustrating muddy dolomite with abundant very coarse-grained sand defining crude parallel lamination sharply overlain by cleaved clast-poor diamictite of the PAF. Cm-scale markings. $\mathbf{d}$. Whole thin section of broken-up dolomite bed in sandy matrix, basal PAF (72.6 m level). Dolomite contains variable siliciclastic impurities; secondary quartz also forms veins and replacive mosaics. e. One of series of truncations of broken-up dolomite beds (like that of photograph d) close to the base of the PAF (72.5 m level). Yellow arrows point along the truncation surface. Scale varies; staff is $2 \mathrm{~m}$ long. $\mathrm{f}$. Sharp lower 
boundary of clast-rich diamictite unit with some alignment of clasts towards the cleavage at $76.5 \mathrm{~m}$ level. g. Horizontal lamination defined by clusters of very coarse-grained sand grains, photograph 30 $45 \mathrm{~cm}$ below diamictite of photograph $\mathbf{f}$. Scale has $\mathrm{cm}$ divisions at top. $\mathbf{h}$. Dolomite bed (86 $\mathrm{m}$ level) exhibiting irregular top (tectonically deformed), interpreted as subaerial exposure surface, overlain by sandy muddy dolomite.

Figure 14. Silicified evaporites from the NE Garbh Eileach section. a. Silicified, ptygmatically folded wedge structure (to left of hammer, centre) composed of quartz and brown-weathering ferroan dolomite. Occurs at boundary of Beds 27 and 28 at a level where dolomitic rather than calcitic lithologies become dominant. Hammer has $5 \mathrm{~cm}$ scale intervals. b. Thin section taken from wedge in a displaying quartz (white) and ferroan dolomite artificially stained blue with potassium ferricyanide. c. Photomicrograph from thin section shown in b illustrating inclusions of anhydrite (squaresectioned crystals with bright, high first-order polarization colours) d. Bedding plane of dolomite with abundant stellate and lensoid gypsum pseudomorphs. Bed 31, scale has $\mathrm{cm}$ at the top. e. Hand specimen from Bed 31 with silicified pseudomorphs weathering in relief (bedding plane view). f. As e but viewed perpendicular to bedding. $g$. Thin section of pseudomorphs (white) within dolomite of Bed 31. h. Photomicrograph from thin section shown in $\mathbf{h}$ illustrating quartz with anhydrite inclusions. i. Bed 38, stellate pseudomorphs of gypsum in dolomite.

Figure 15. Summary lithostratigraphy and carbon isotope profile for the NE Garbh Eileach section.

Figure 16. Cross-plots of carbon and oxygen isotopes in the section shown in Fig. 15 for a) limestones and b) dolomites. Basal dolomite raft in Great Breccia includes D1 clasts as well as bedded dolomites. There is no isotope covariation within individual groupings of limestone or dolomite samples and $\delta^{13} \mathrm{C}$ values are interepreted as primary. Limestone clasts in the PAF have higher $\delta^{13} \mathrm{C}$ values than the GEF limestones and are interpreted as being eroded from deeper stratigraphic levels than currently exposed on the Garvellachs. Dolomite samples are interpreted to have variably exchanged oxygen isotopes with fluids during burial, samples in the raft probably being close to the original sedimentary composition.

Figure 17. a. Offshore geology of the Garvellachs based on bathymetry derived from multibeam echo sounder surveys. Bathymetry data are gridded at $5 \mathrm{~m}$ horizontal resolution (colour scale 0-200 m depth), and provided courtesy of the Maritime Coastguard Agency's UK Civil Hydrography Programme - Crown Copyright. The Garvellachs (black, centre) lie within an extensive homocline of SE-dipping Dalradian strata with only minor faulting (red dashed lines). The stratigraphically highest Dalradian unit shown on the image is the ca. $5 \mathrm{~km}$-thick Jura Quartzite which overlies the $300 \mathrm{~m}$ Bonahaven Formation (not differentiated), ca. $1 \mathrm{~km}$ of Port Askaig Formation (PAF), and finally the Appin Group. The strike of the last is defined by ridges and furrows of harder and softer lithologies indicating that a succession $>1.5 \mathrm{~km}$ crops out on the sea floor (see cross-section along line A-B), being terminated by an unconformity (yellow dashed line) beneath continental (?Silurian) Old Red Sandstone (ORS). Drill-sites 1 and 4 are illustrated by stars. b. Laminated pale grey limestone sample recovered from $2.5 \mathrm{~m}$ depth at drill-site 1 thought to be a similar stratigraphic level to the base of the GEF (scale in $\mathrm{mm}$ ). c. Black limestone (0.9 m depth, drill-site 4 ) containing molar tooth structure (m) cut by planar white calcite tectonic veins. Sample thought to represent the Ballachulish Limestone Formation. Scale in $\mathrm{mm}$ and $\mathrm{cm}$.

Figure $18^{87} \mathrm{Sr} /{ }^{86} \mathrm{Sr}$ versus $1 / \mathrm{Sr}$ plot for Appin Group samples of Islay and Garbh Eileach. Where multiple leaches have been carried out (Fig. 19), only the minimum ${ }^{87} \mathrm{Sr} /{ }^{86} \mathrm{Sr}$ is plotted. Results show that even with optimal Sr concentrations $(1 / \mathrm{Sr}<0.0005),{ }^{87} \mathrm{Sr} /{ }^{86} \mathrm{Sr}$ varies by 0.0002 to 0.0003 in a given stratigraphic unit. The lowest values of ${ }^{87} \mathrm{Sr} /{ }^{86} \mathrm{Sr}$ characterize the youngest pre-glacial unit, the Garbh Eileach Formaton. 
Figure 19. Results of successive leachates in the Anderson study where N1 and N2 are pre-leaches and S1 to S13 are acid leachates as itemized in Table S5. a. Variation in ${ }^{87} \mathrm{Sr} /{ }^{86} \mathrm{Sr}$. b. Variation in $\mathrm{Rb} / \mathrm{Sr}$. See text for discussion.

Figure 20. Summary carbon and strontium isotope chemostratigraphy of the late Tonian to carbonates of the Argyll succession, Scotland with suggested basal Cryogenian boundary. Formation names on right-hand column. Limestones are denoted by blue or green symbols and dolomites by brown symbols. Shelfal and peritidal environments (right) mostly correspond respectively to shales and limestones for the former and dolomites for the latter. The Persabus Member of the Lossit Formation (also truncated above by the erosional base to the PAF) is omitted, but fills some of the missing interval. 'Brasier' and 'Thomas' refer to data in Brasier \& Shields (2000) and Thomas et al. (2004) respectively. 
Fairchild et al. Figure 1
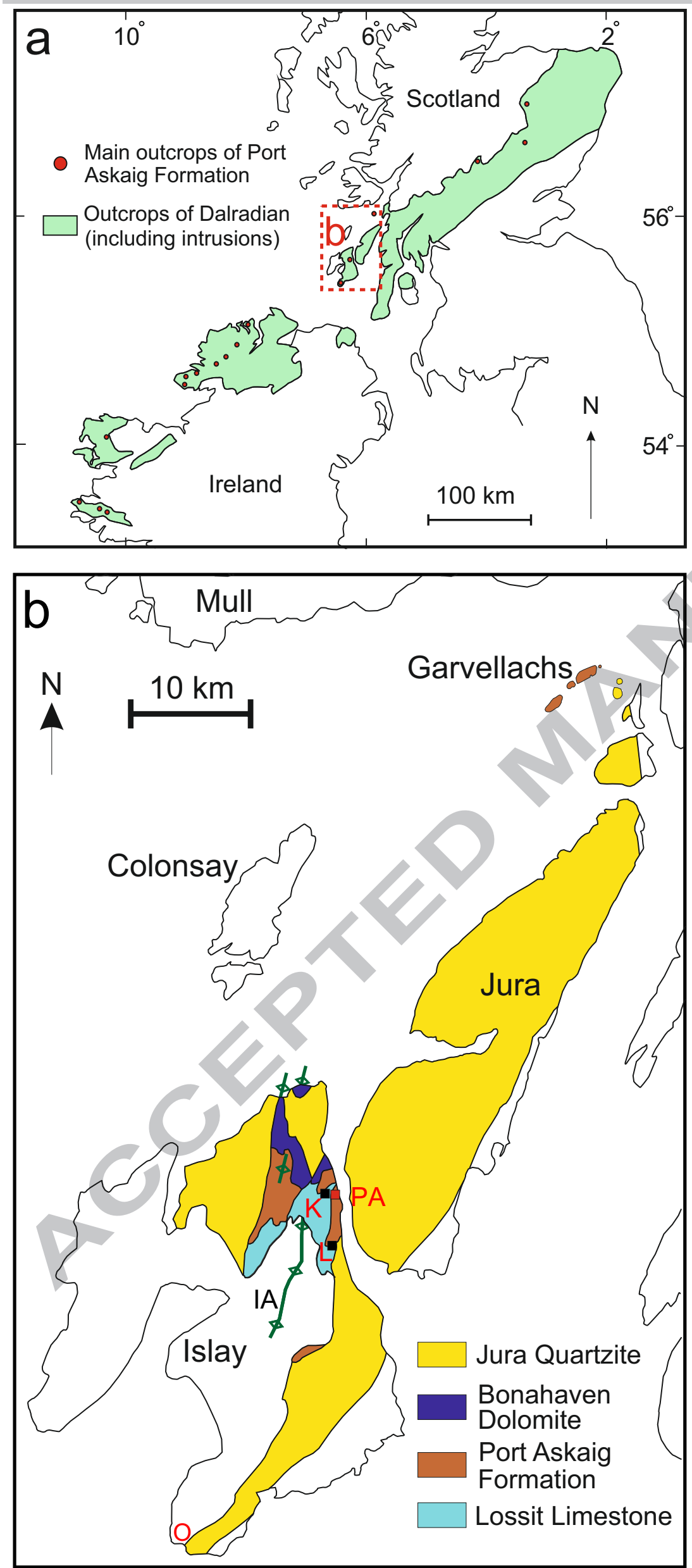


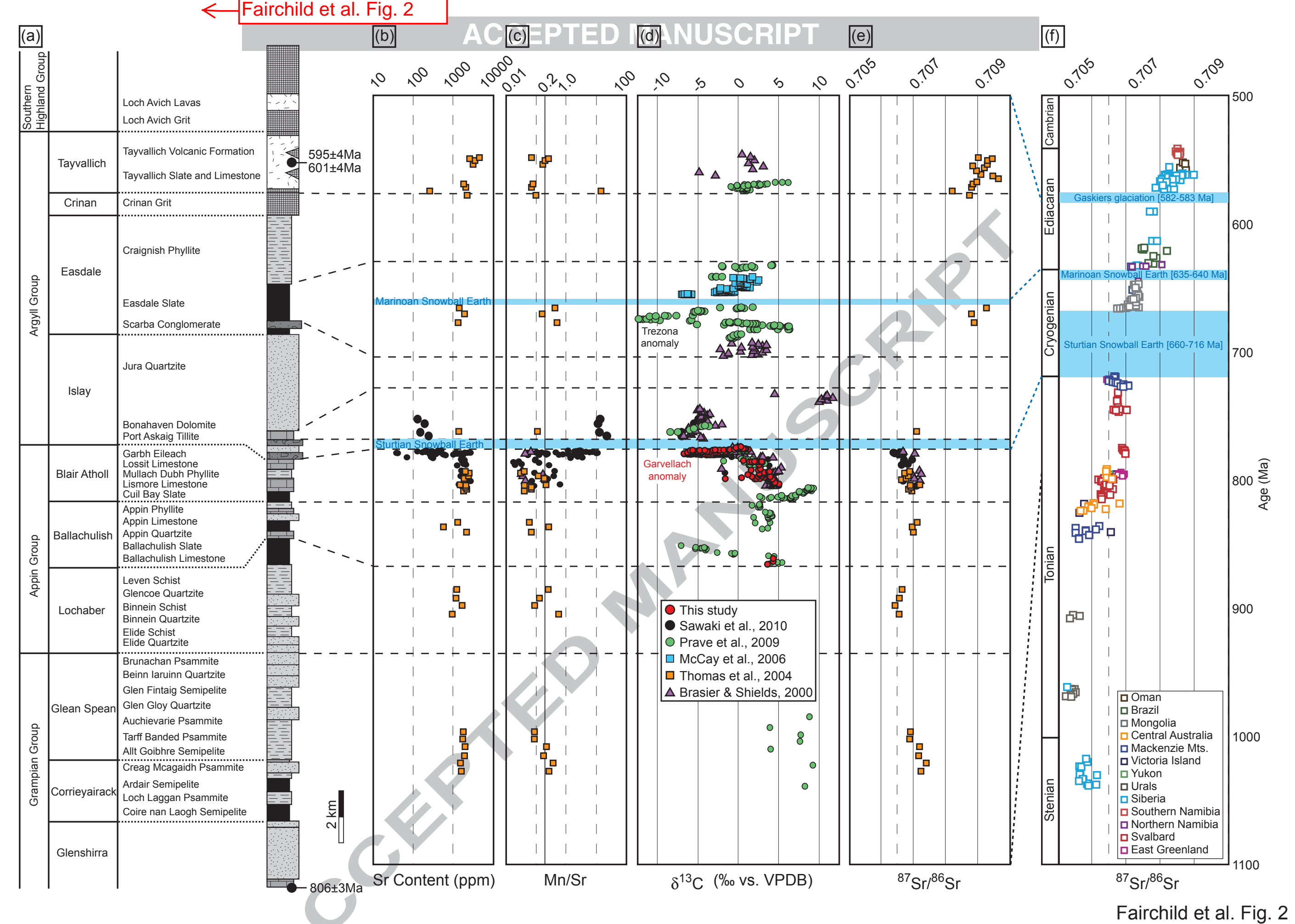



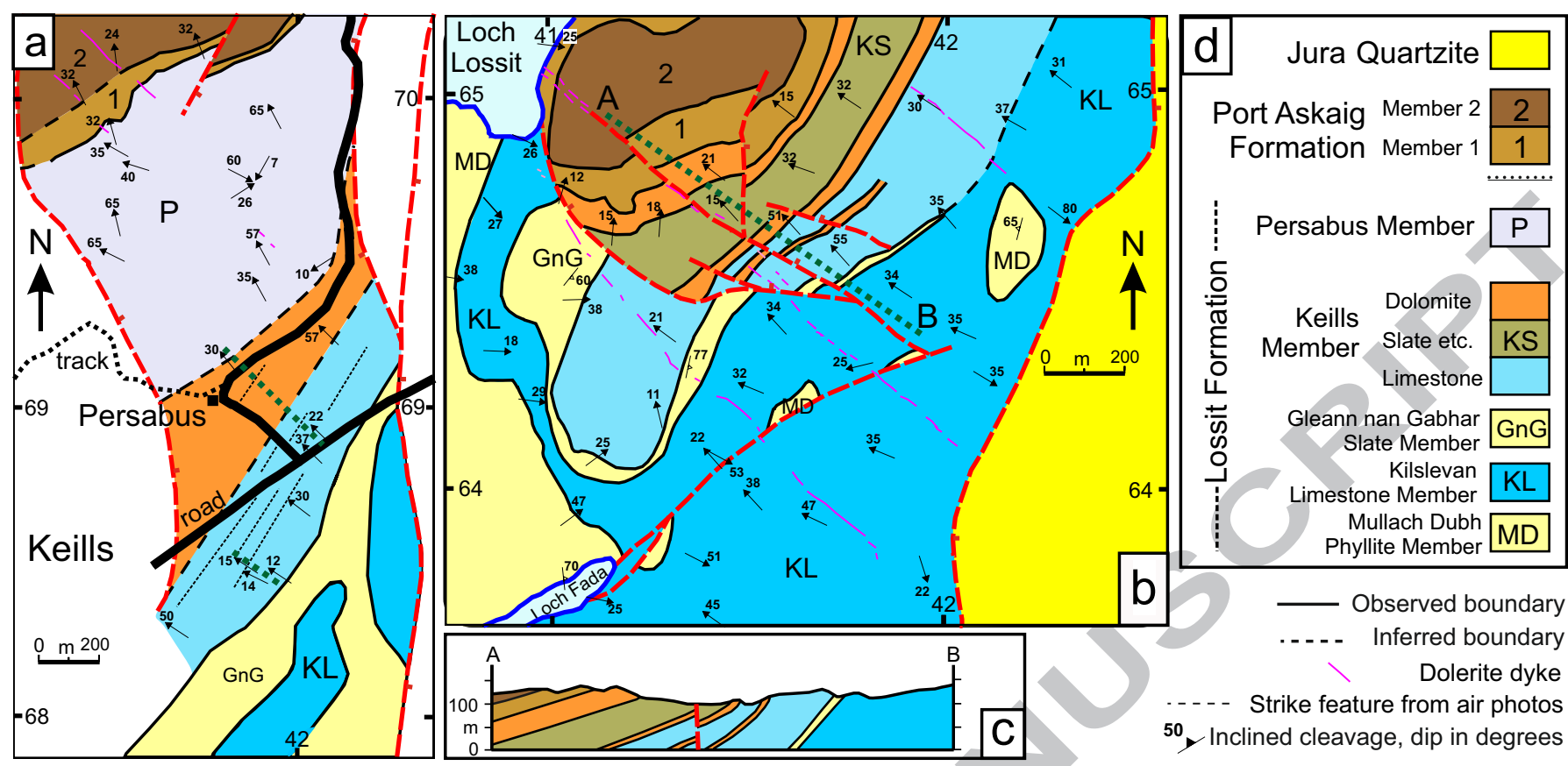

Strike feature from air photos

50 Inclined cleavage, dip in degrees

-ـ-Fault, with sense of downthrow Ж Fig. 9 profile locations $\quad$...... Lines of stratigraphic profiles

${ }^{35} \mathrm{~K}$ Inclined strata, dip in degrees
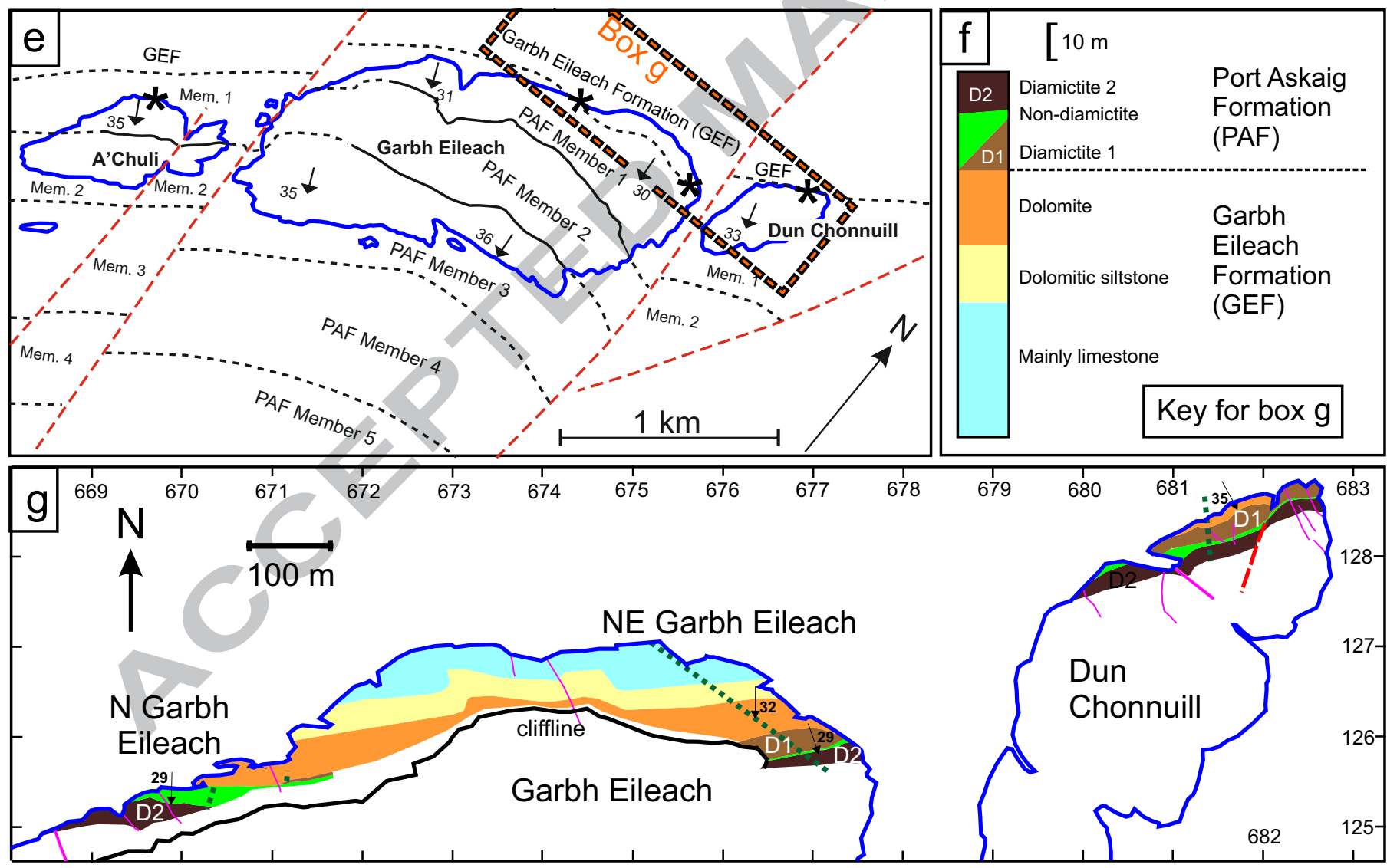


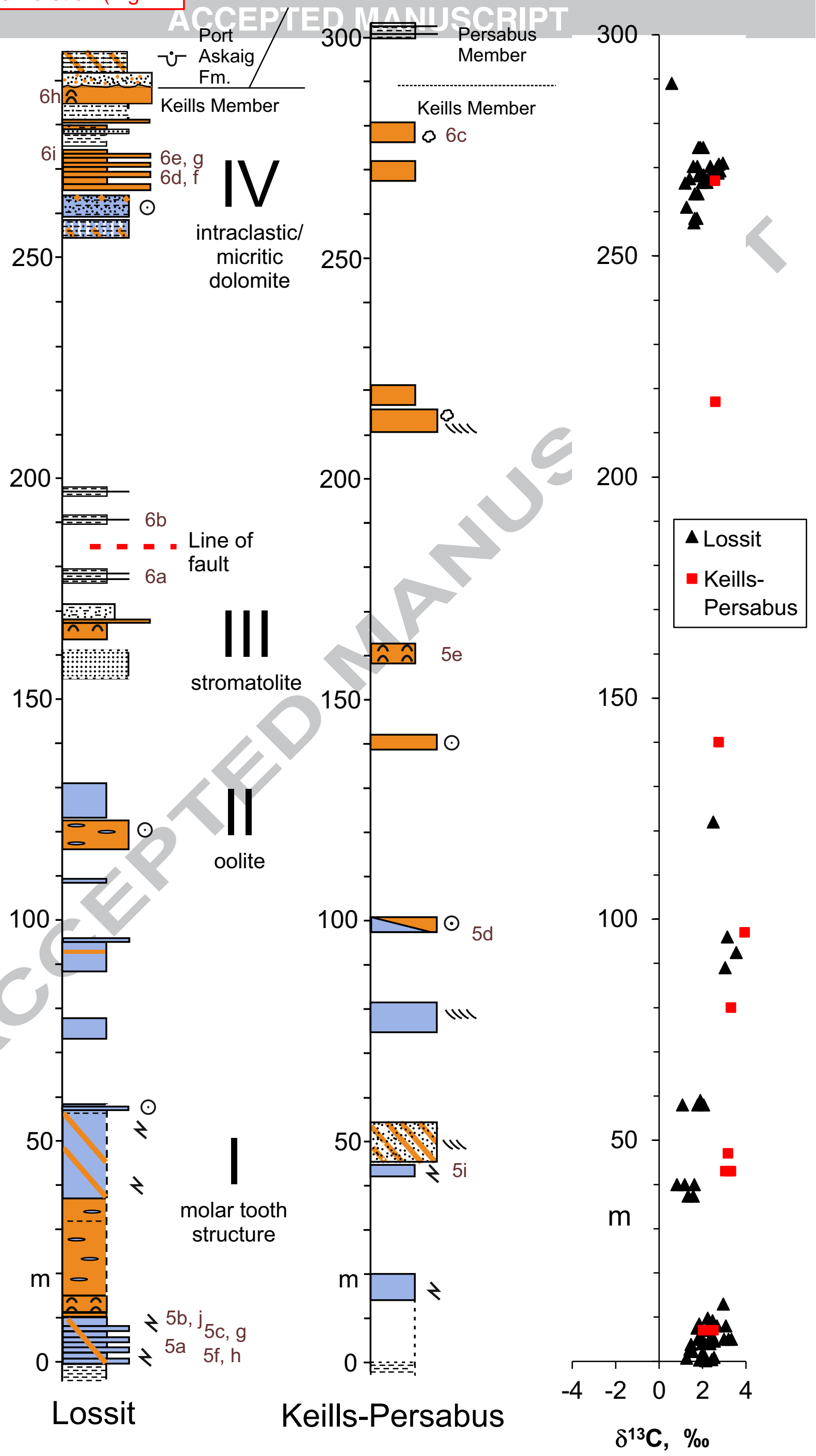


Fairchild et al. Figure 6
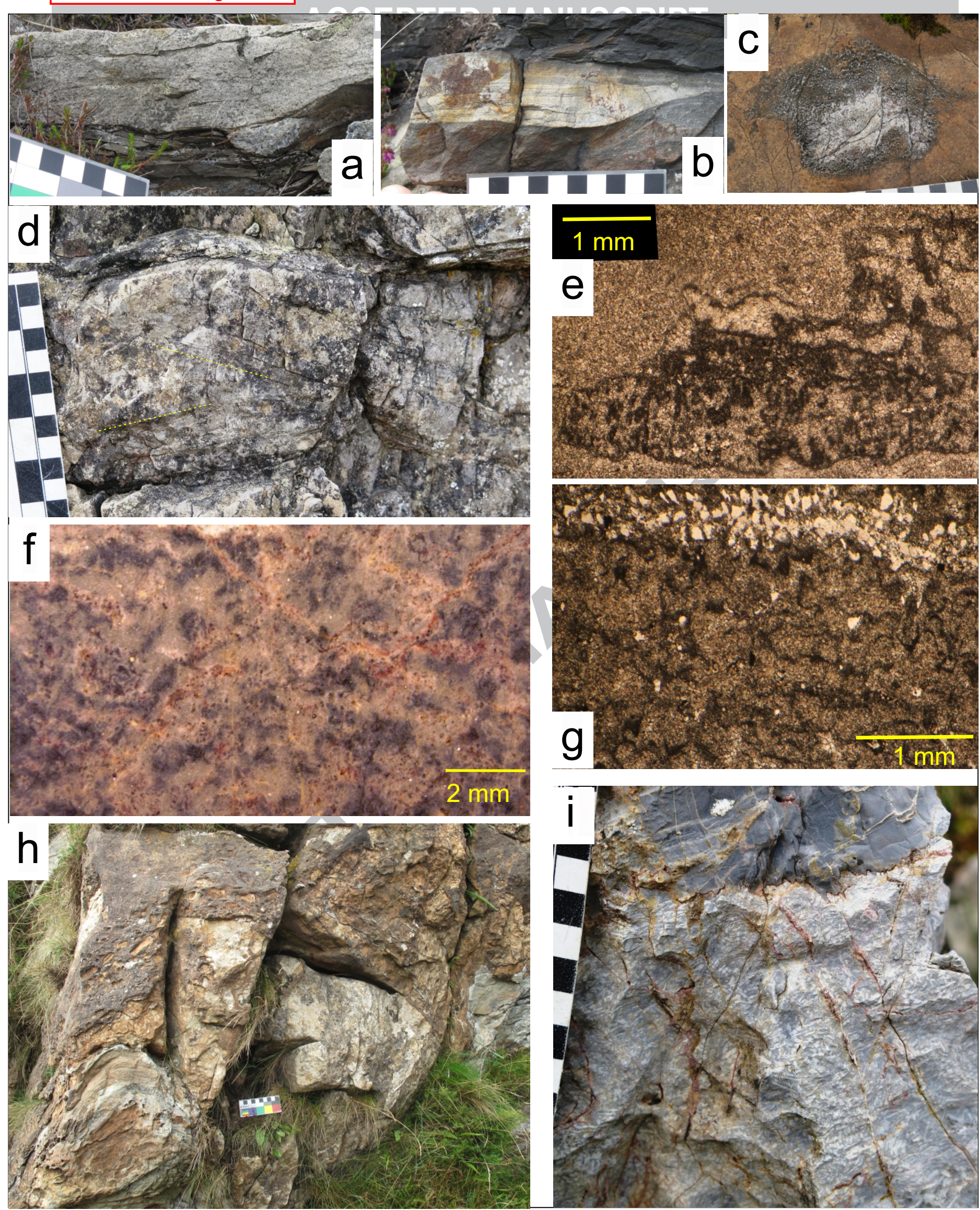


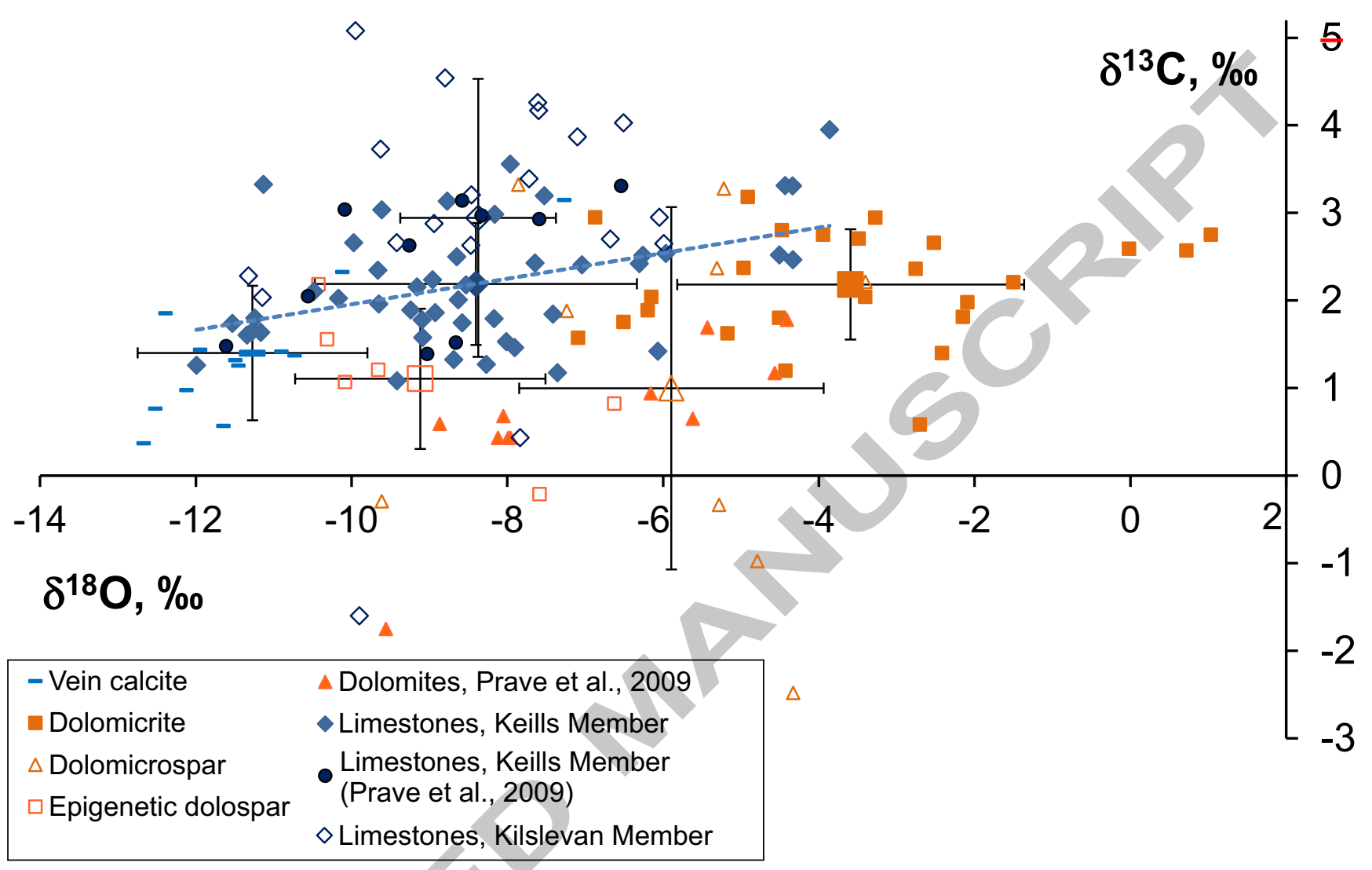




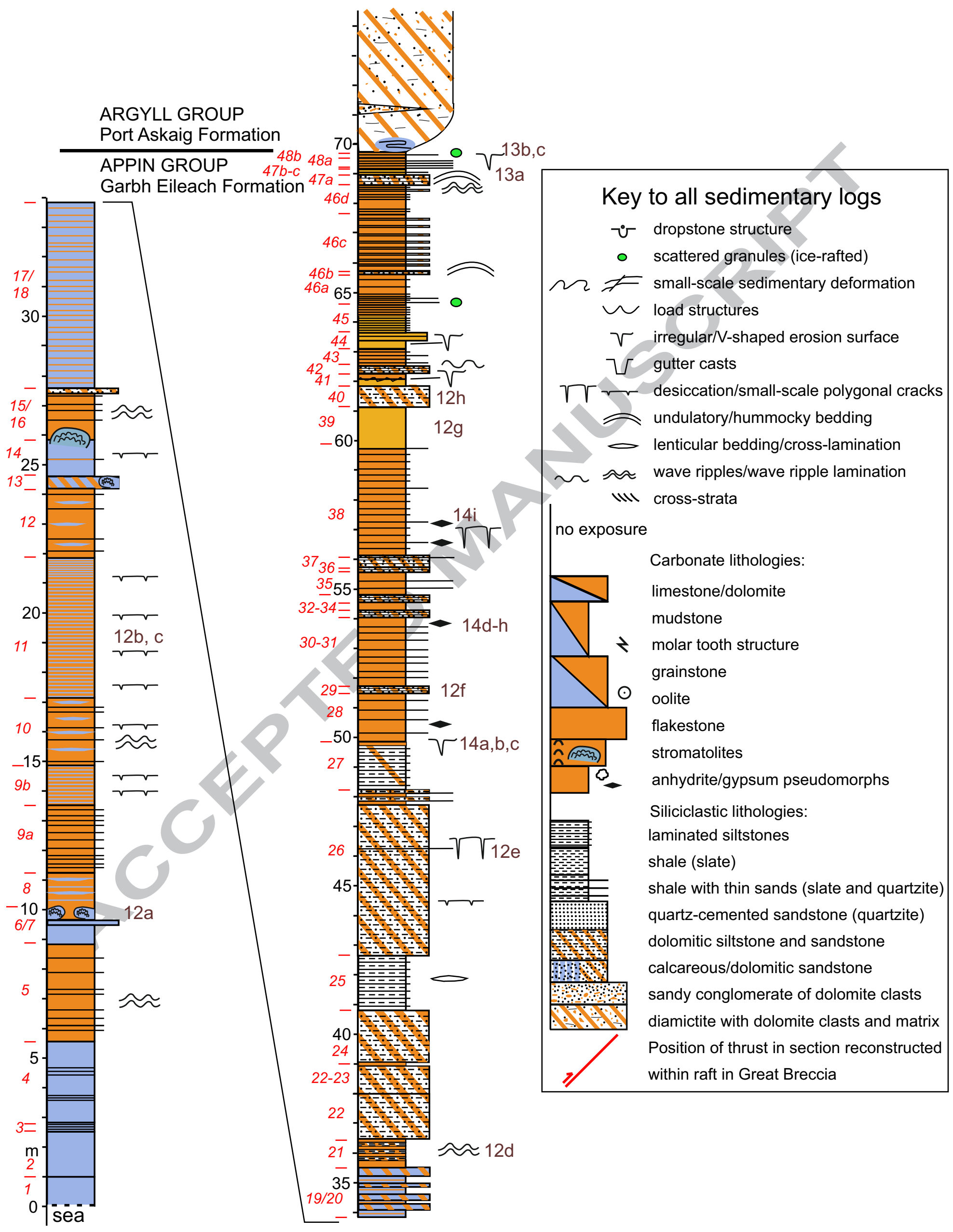




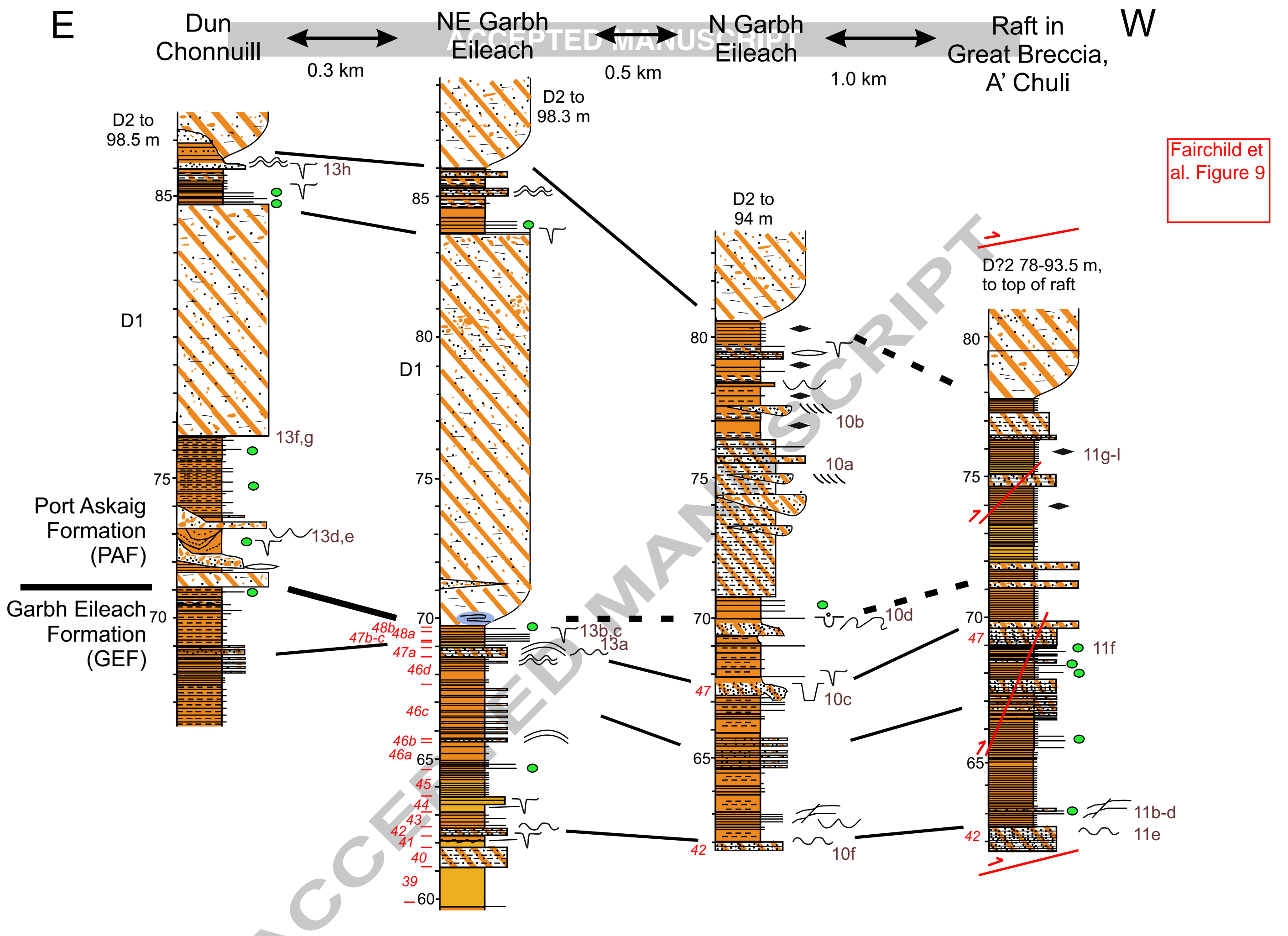



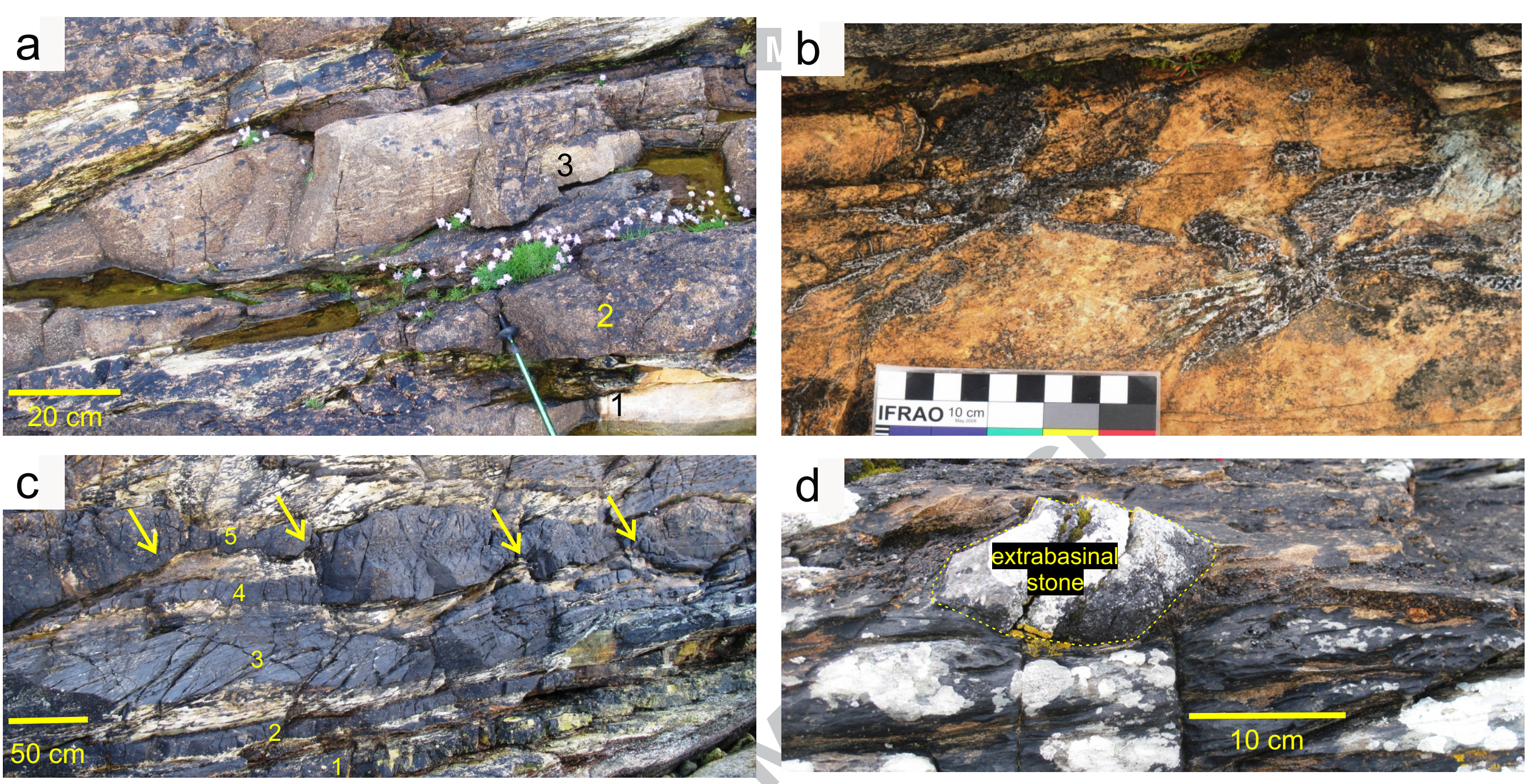

$\mathrm{e}$

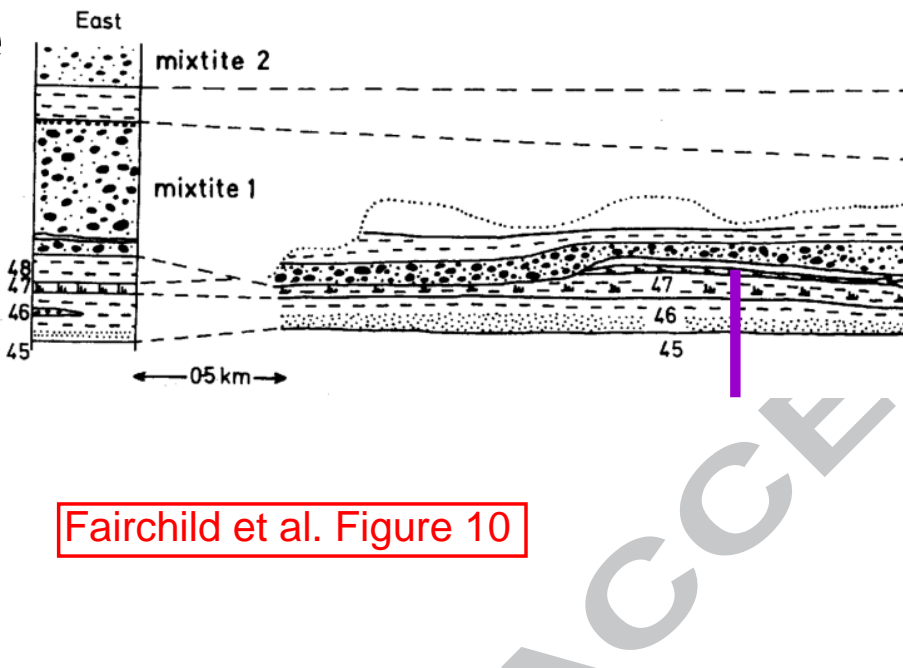




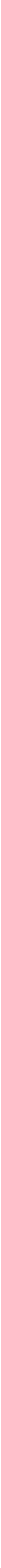



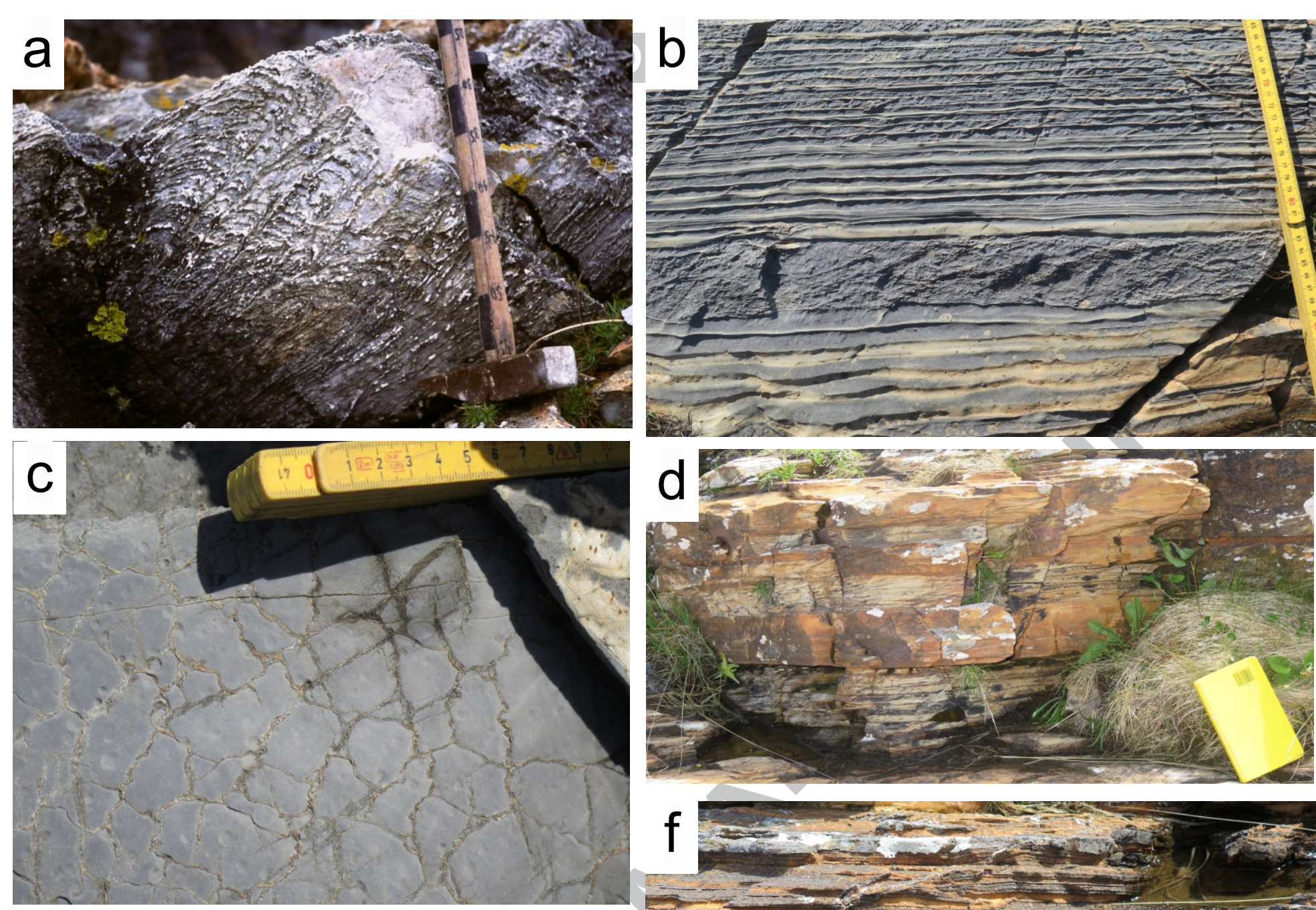

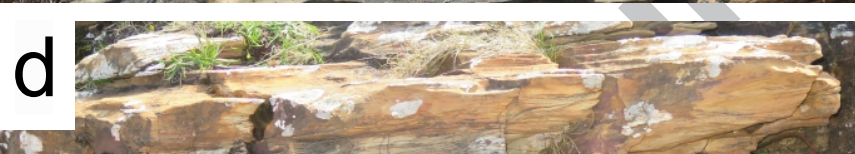

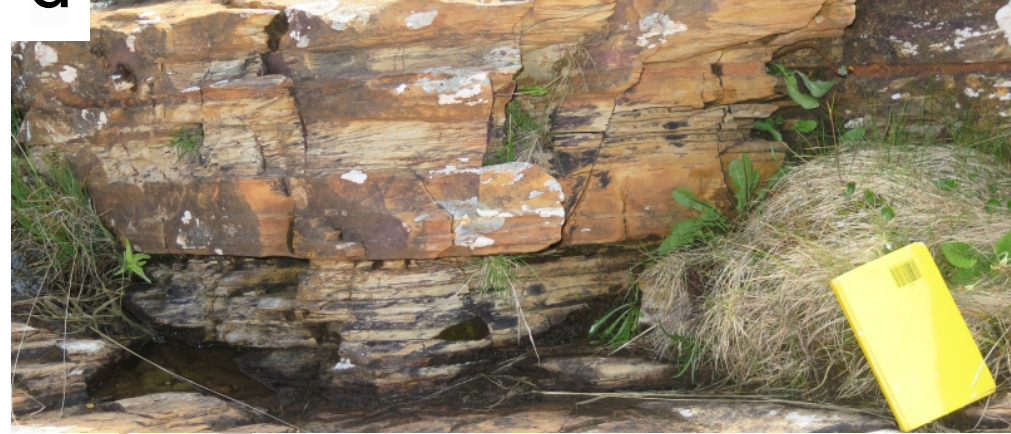

\section{e}

$f=2-3 x$
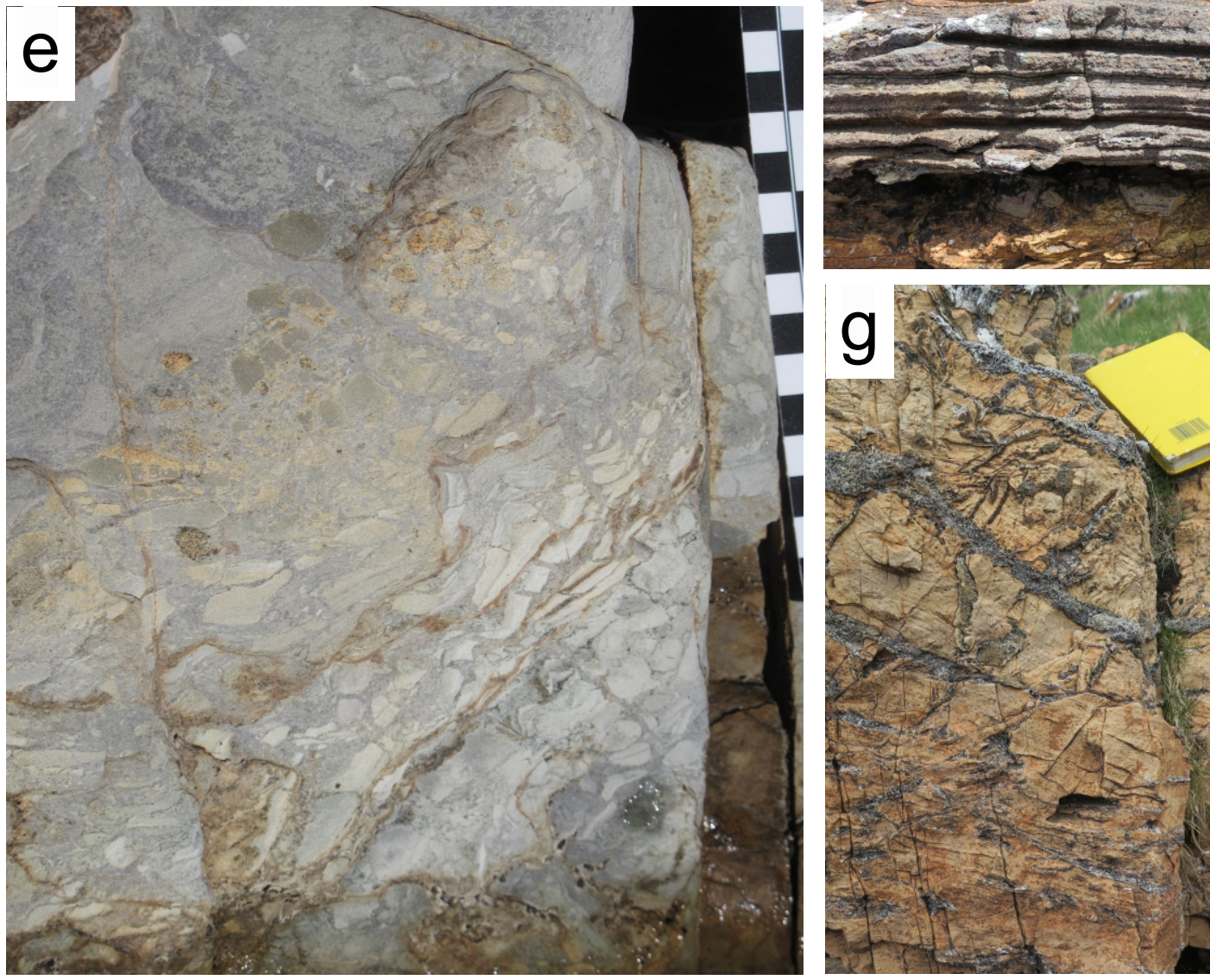

$\mathrm{h}$

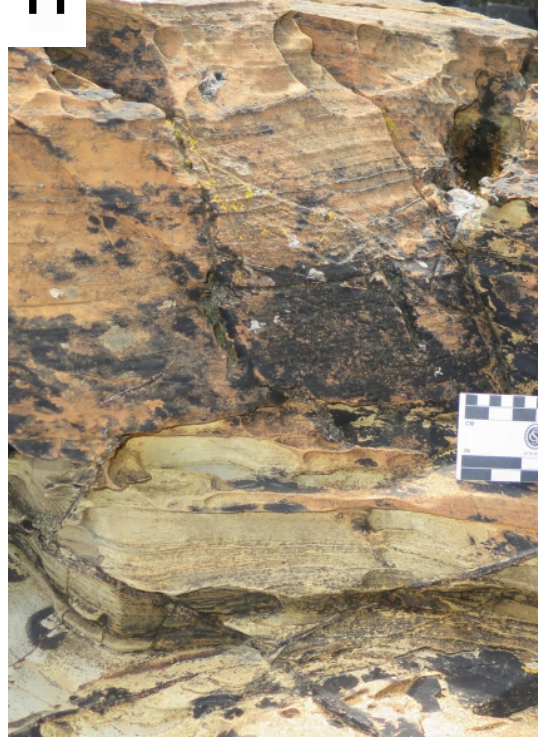

Fairchild et al. Figure 12 
Fairchild et al. Figure 13
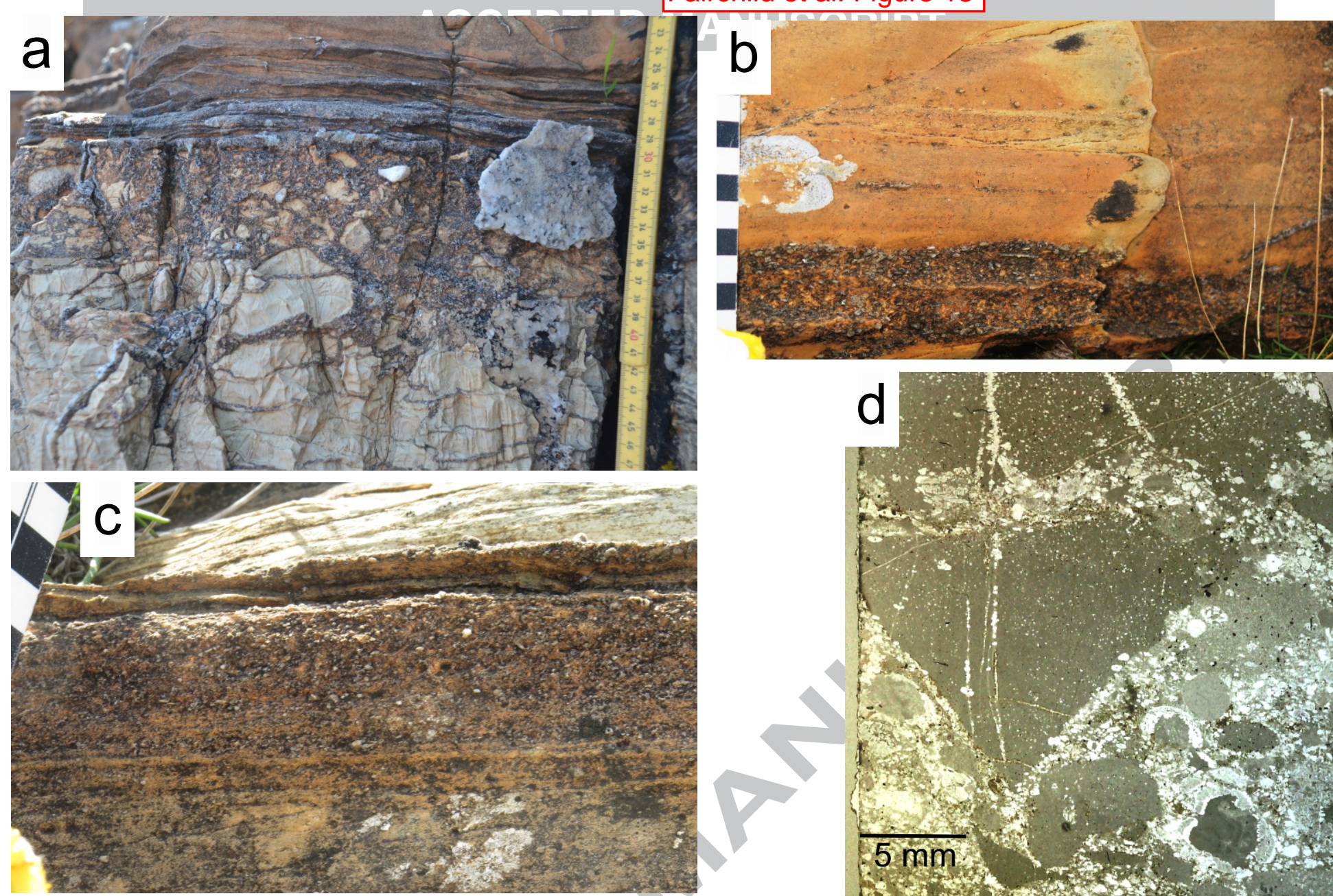

e $-2 x-2 x^{2}=$

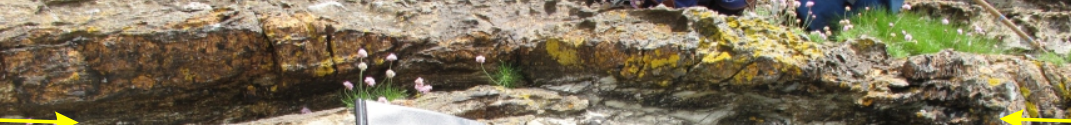

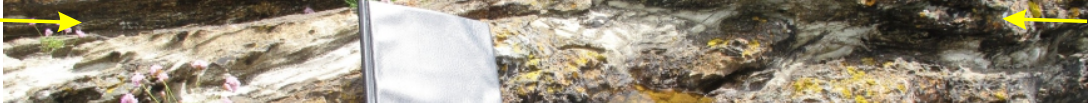

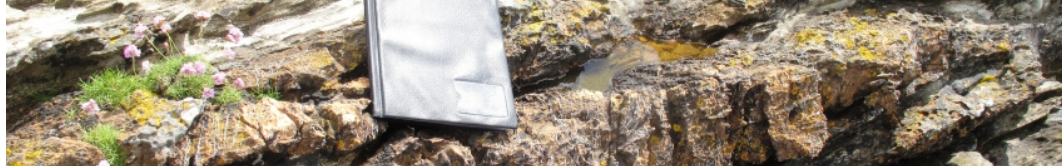
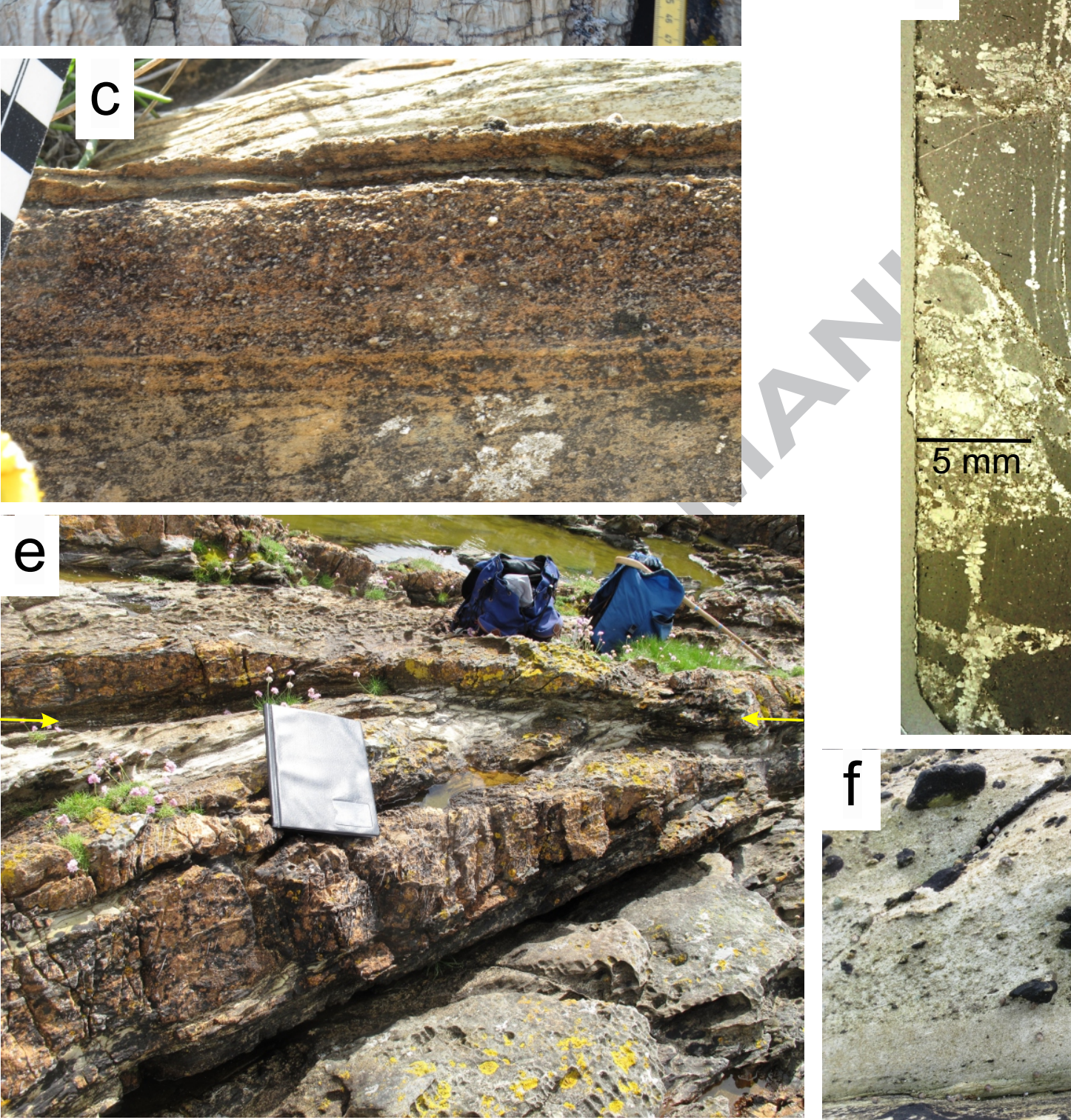

H. $-0^{2}-1,3$

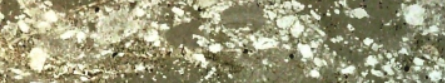

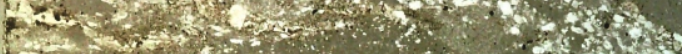
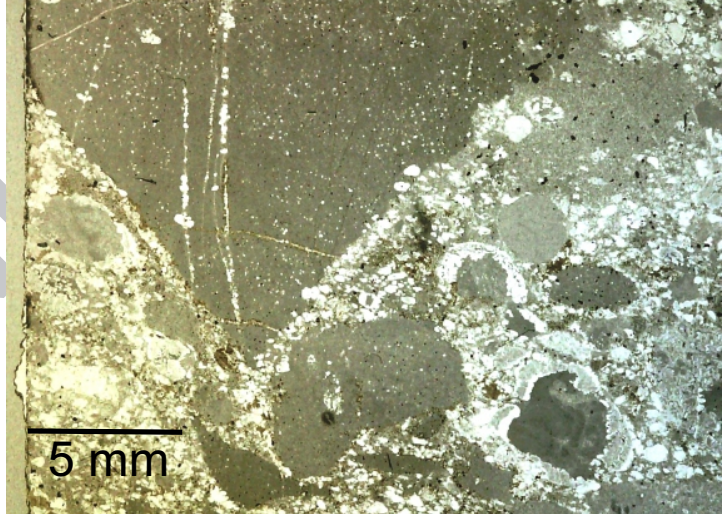

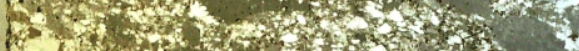
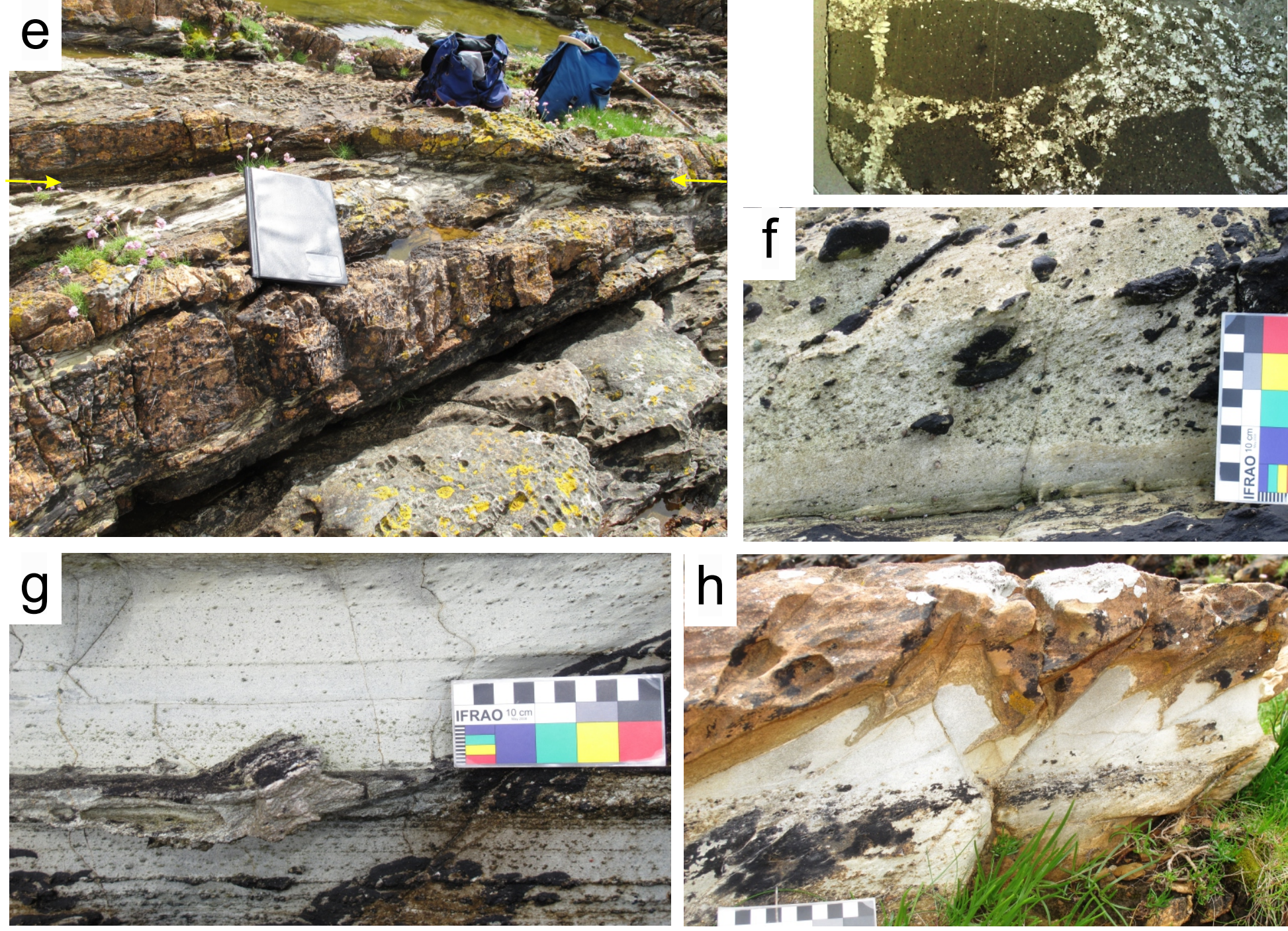


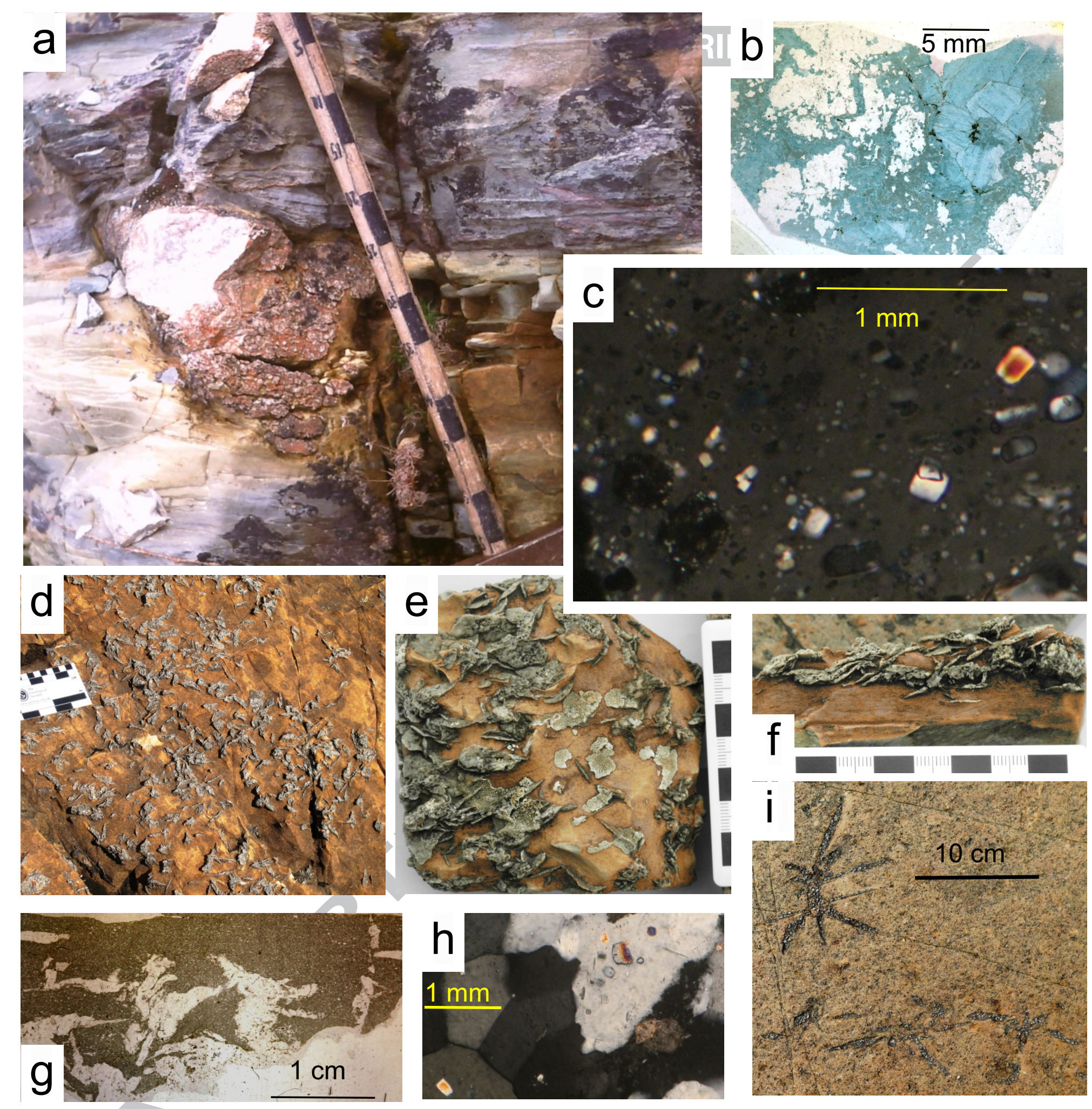




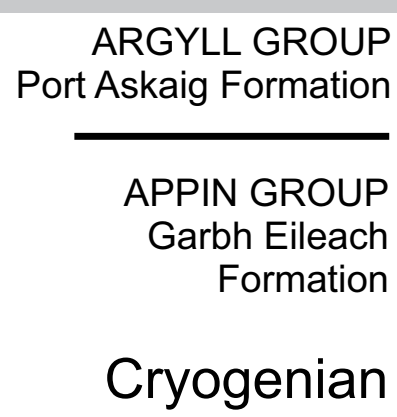

boundary proposal

Tonian
40
39 


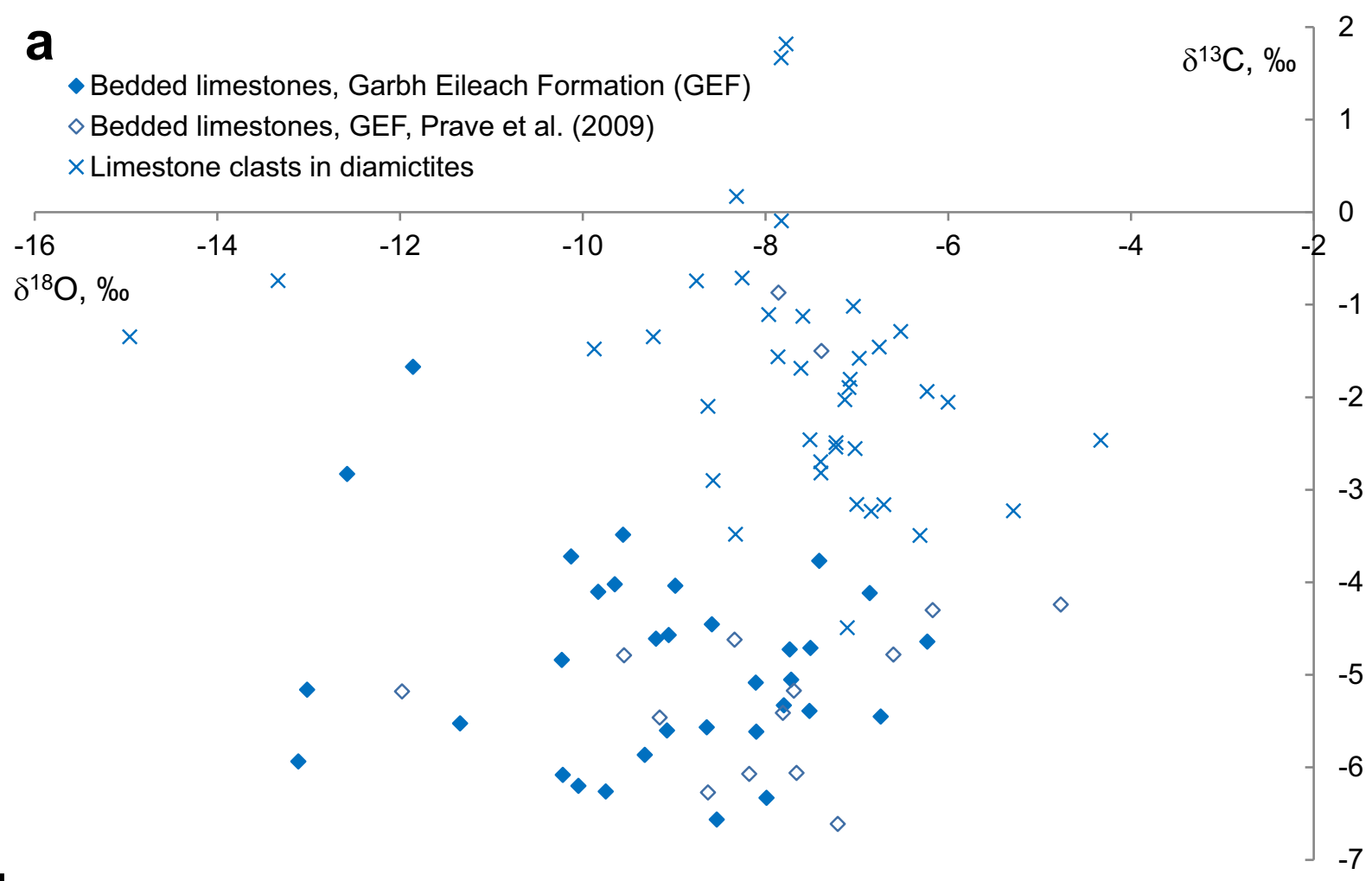

b

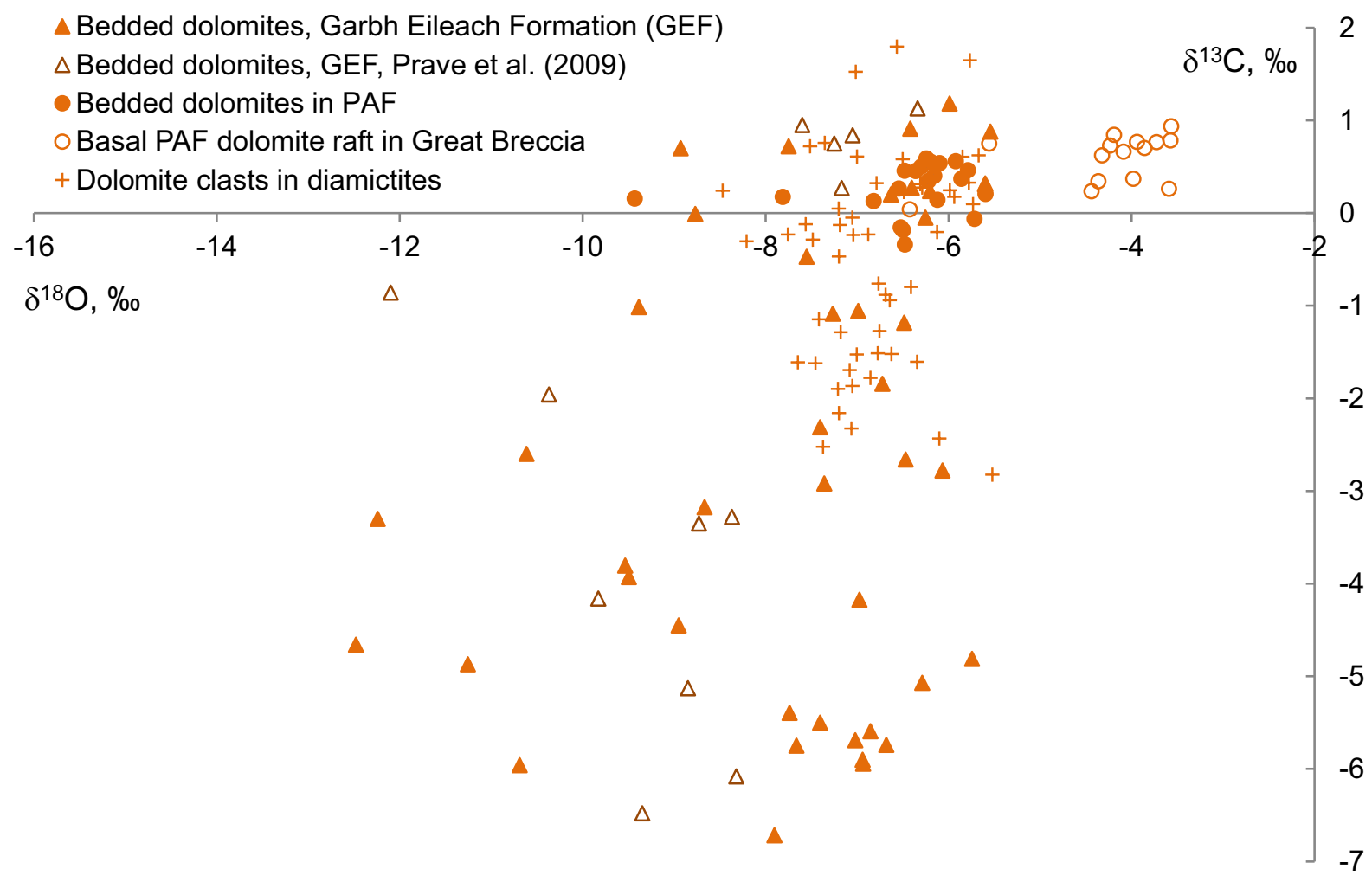



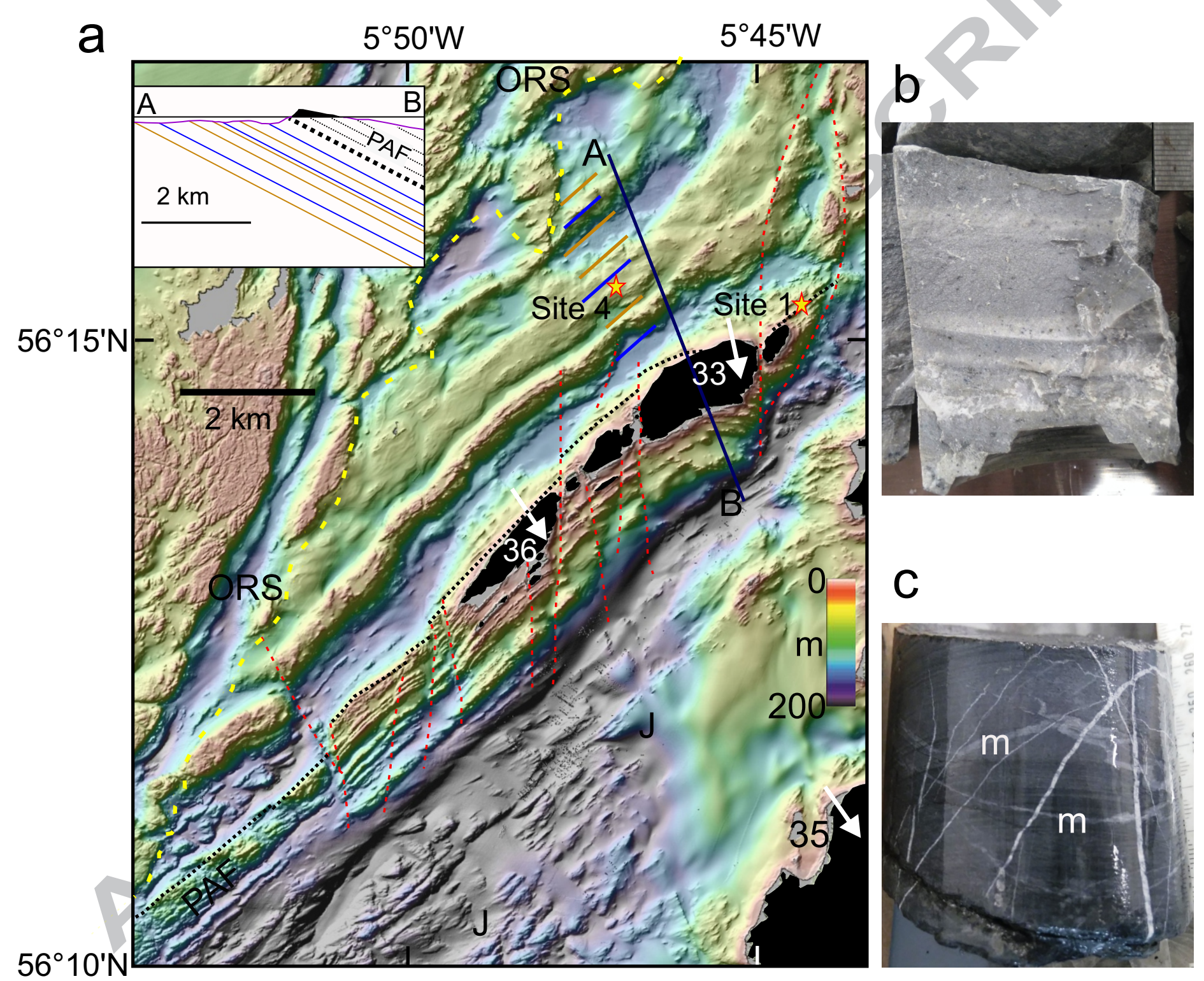

C

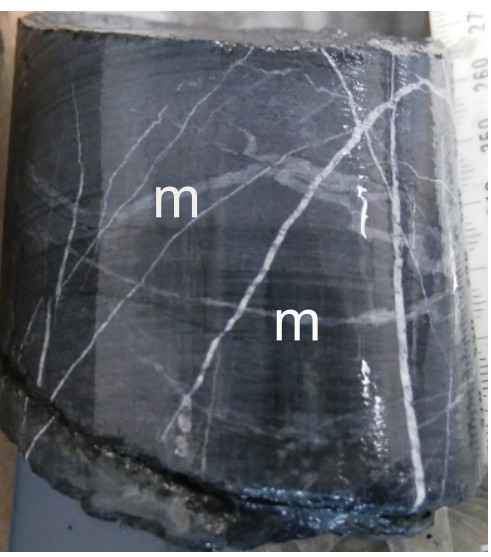




\section{Fairchild et al. Figure 18}

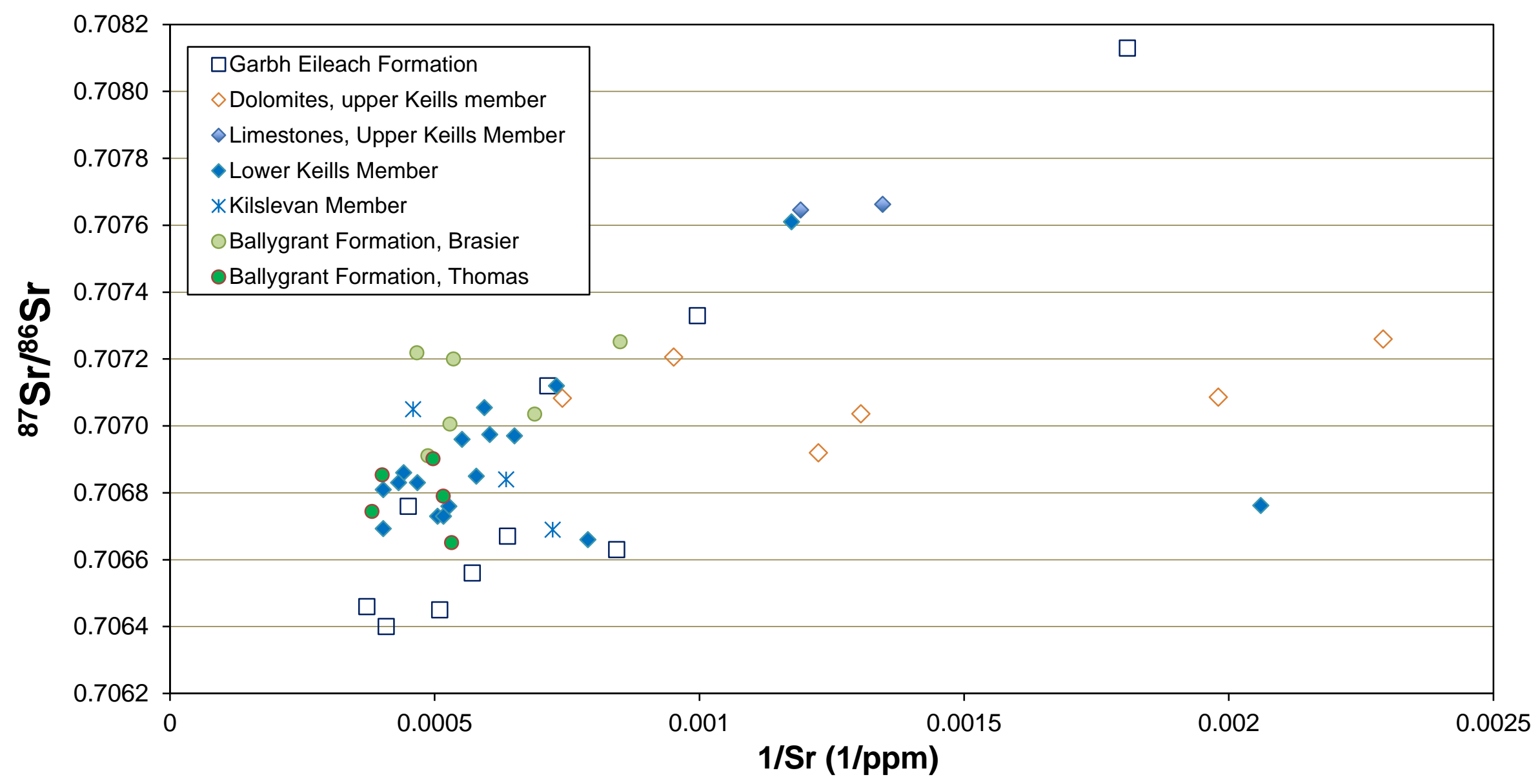




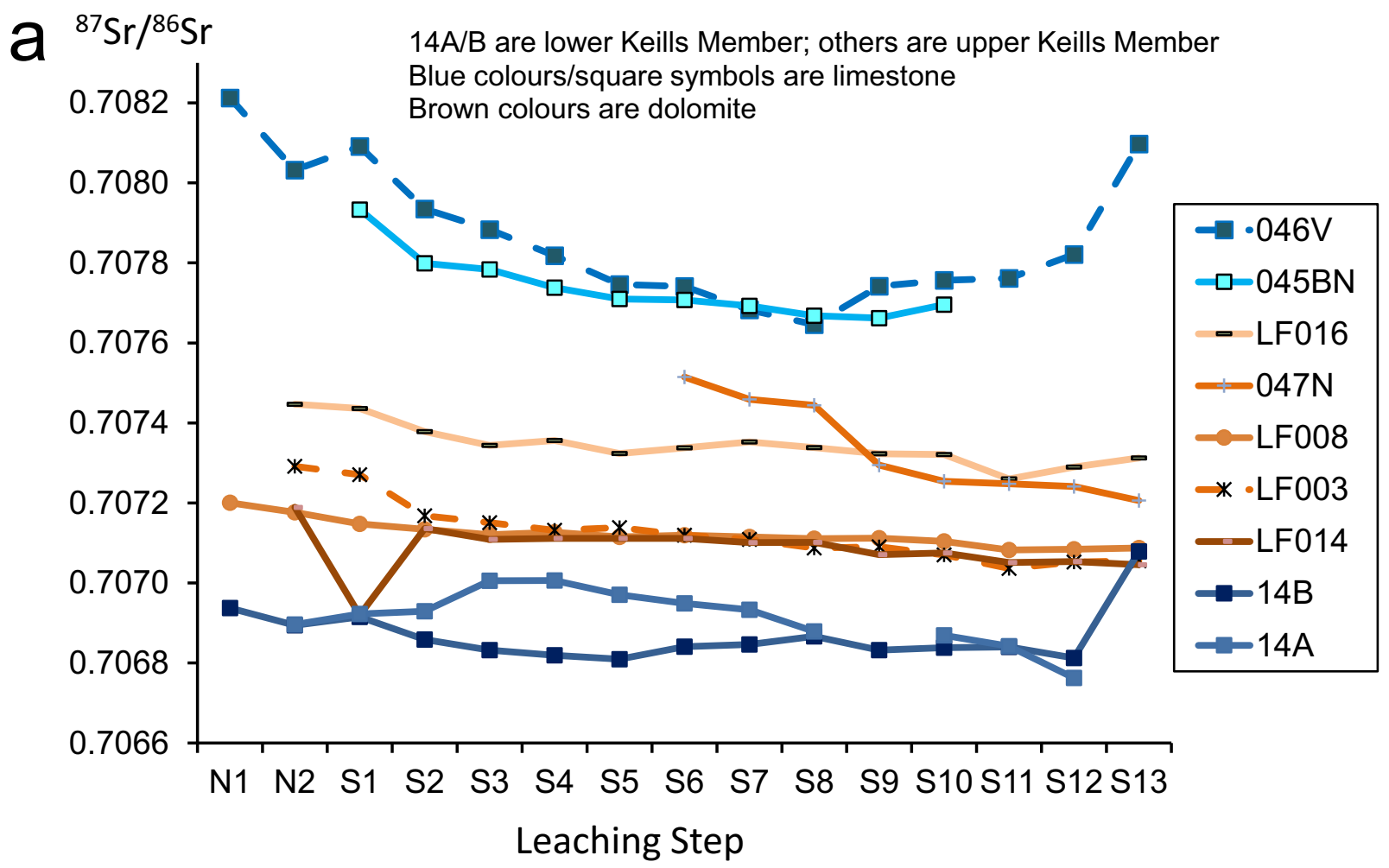

b $\mathrm{Rb} / \mathrm{Sr}$

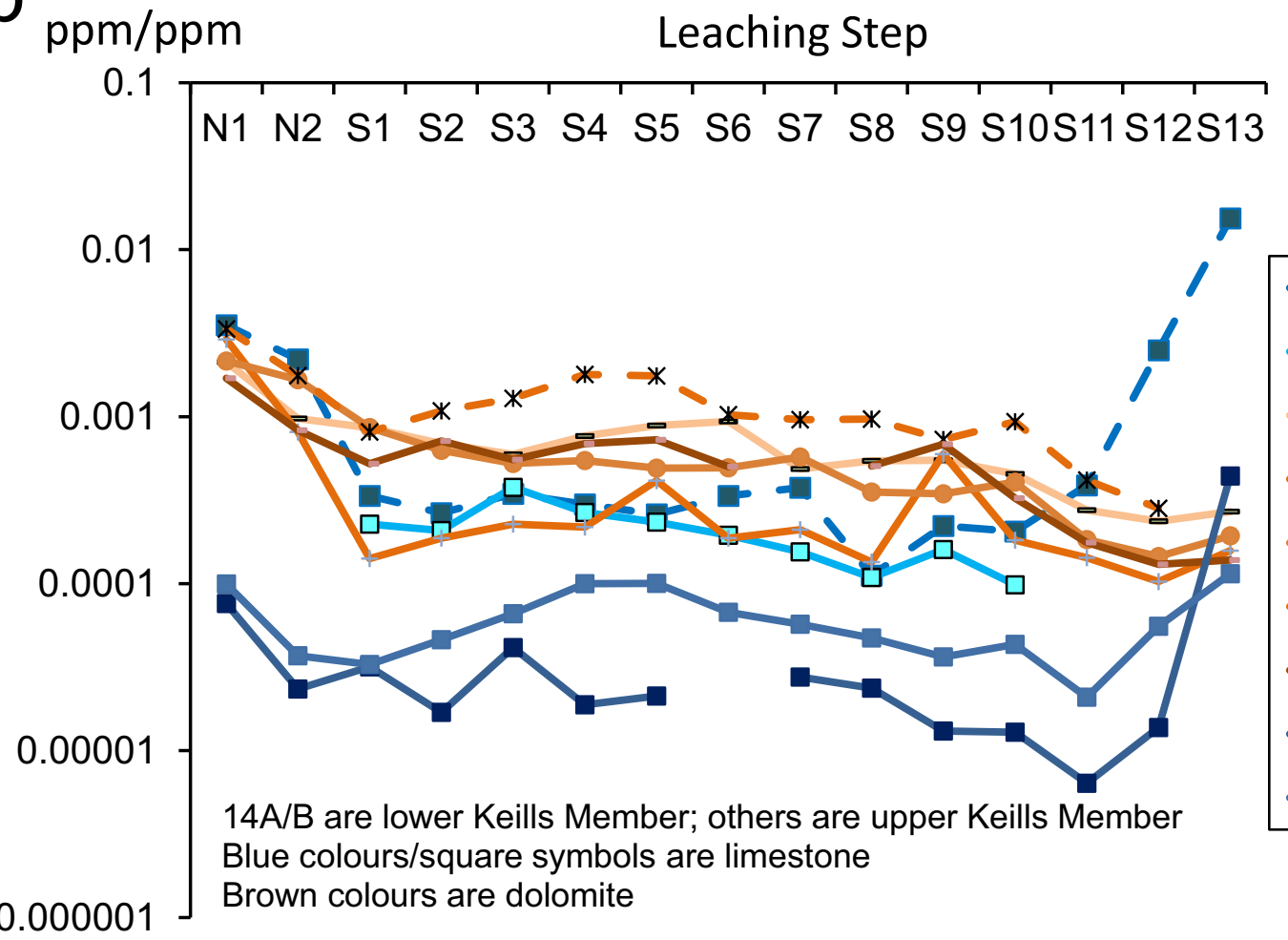

$-046 \mathrm{~V}$
$-\square-045 \mathrm{BN}$
- LF016
$-047 \mathrm{~N}$
$-\mathrm{LF} 008$
$--\mathrm{LF} 003$
$-\mathrm{LF} 014$
$-14 \mathrm{~B}$
$-14 \mathrm{~A}$

Blue colours/square symbols are limestone 


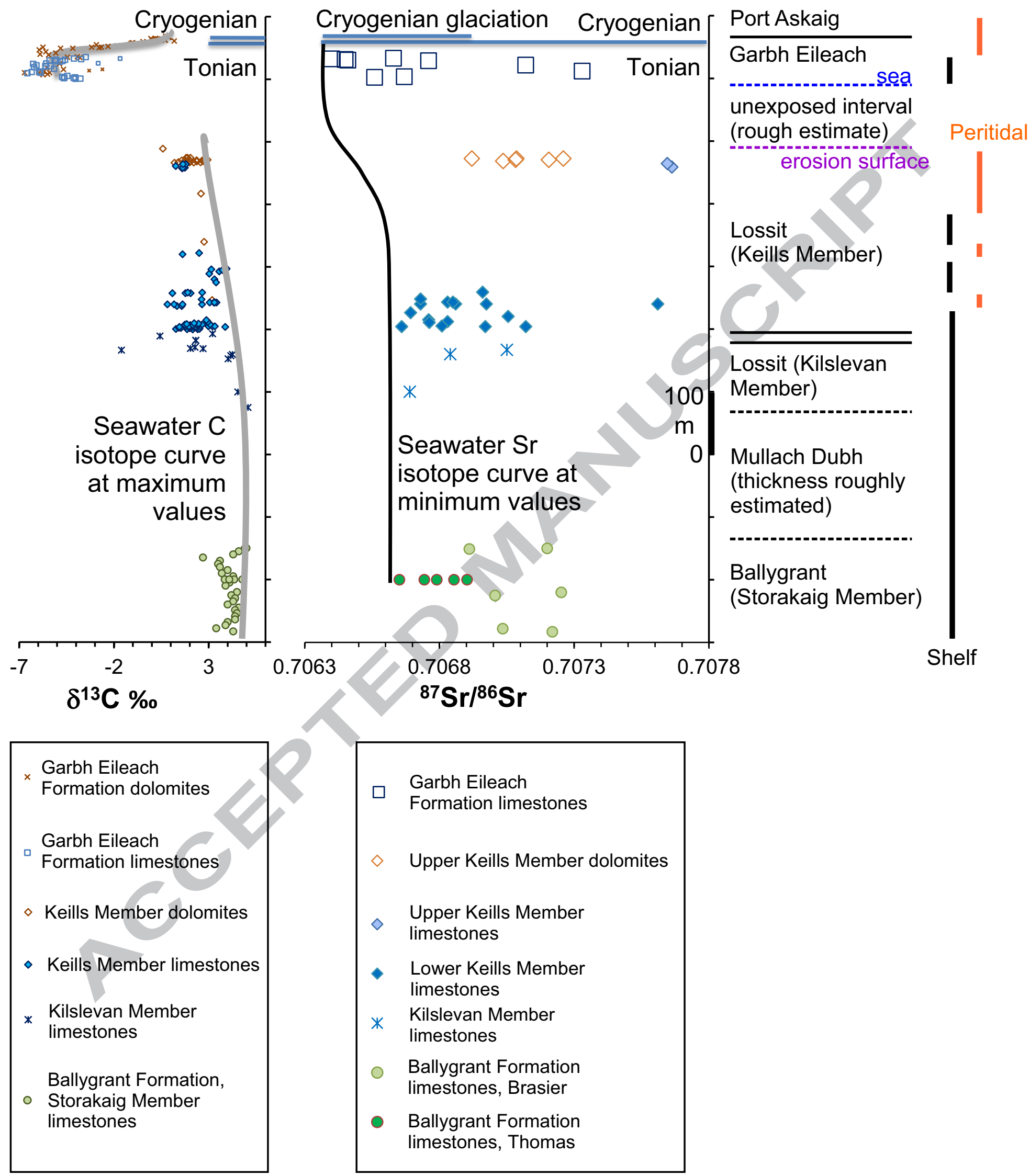

